DOE/EA- -0389

DE91 004303

ENVIRONMENTAL ASSESSMENT OF THE PROPOSED

7-GEV ADVANCED PHOTON SOURCE

\title{
February 1990
}

\author{
Prepared by the \\ U.S. DEPARTMENT OF ENERGY
}




\section{CONTENTS}

Page

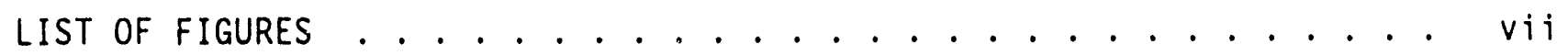

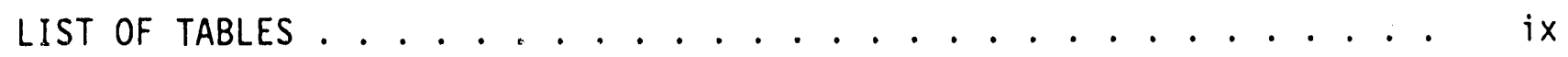

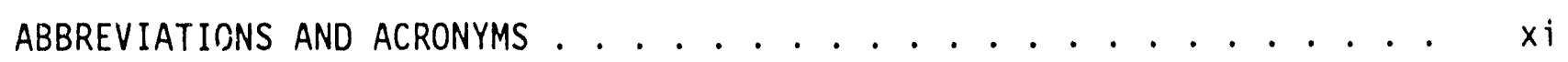

ABSTRACT ........................................ xi

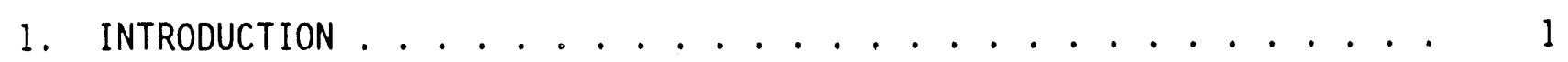

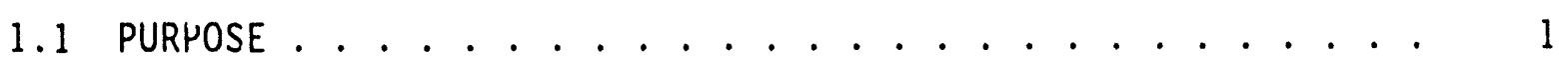

1.2 THE APS PROJECT AT ANL . . . . . . . . . . . 2

1.3 SUMMARY OF THE PROPOSED ACTION ............... 4

1.4 NEED FOR ACTION .................... . . . 4

2. THE PROPOSED ACTION AND ALTERNATIVES . . . . . . . . . . . 9

2.1 DESCRIPTION OF APS AND CONSTRUCTION ACTIVITIES (PROPOSED
ACTION) . . . . . . . . . . . . . . . . 9

2.1.1 APS Facility Description .......... . . 9

2.1.2 Utility Services ............. 12

2.1.3 Gaseous Emissions, Liquid Effluents, and Wastes... 14

2.1 .4 Construction Activities ........... 16

2.1 .5 Decommissioning . . . . . . . . . . 19

2.2 Alternatives . . . . . . . . . . . . . 22

2.2.1 No Action.............. . . 22

2.2.2 Construction at Another ANL Site........ 22

3. THE AFFECTED ENVIRONMENT . . . . . . . . . . . 25

3.1 SITE DESCRIPTION .................... 25

3.2 ClimatologY AND AiR QUALITY .............. 25

3.2.1 Climatology ................ . . . 25

3.2 .2 Air quality. . . . . . . . . . . . . . 27

3.3 DEMOGRAPHY AND SOCIOECONOMIC PROFILE . . . . . . . . . 32 
3.4 LAND USE . . . . . . . . . . . . . . . . . 34

3.4.1 Site and Vicinity................. 34

3.4.2 Archaeological and Historic Sites........ 35

3.4.2.1 Prehistoric cultural resources . . . . . 35

3.4.2.2 distoric cultural resources . . . . . . . 36

3.5 GEOLOGY .......................... 38

3.5.1 Stratigraphy ................. 38

3.5 .2 Soils .................. . 39

3.5.3 Seismicity . . . . . . . . . . . . . . . . 40

3.6 SURFACE WATER ...................... 43

3.6.1 Hydrology ................... 43

3.6 .2 Quality................... 45

3.6 .3 Use ................... 45

3.7 GROUNDWATER ....................... 48

3.7.1 Use ....................... 49

3.7 .2 Quality ..................... 49

3.8 ECOLOGY ...................... 50

3.8.1 Terrestrial Biota ................ 50

3.8.2 Floodplains and Wetlands ............ 53

3.8.3 Aquatic Biota. . . . . . . . . . . . . . . . 56

3.8.4 Threatened and Endangered Species........ 58

3.9 EXISTING ENVIRONMENTAL MONITORING PROGRAMS . . . . . . 59

3.9.1 Radiological ................ 59

3.9.2 Nonradiological .............. 61

4. ENVIRONMENTAL CONSEQUENCES OF THE PROPOSED ACTION ........ 65

4.1 CONSTRUCTION IMPACTS ............... 65

4.1.1 Land Use and Disturbance ............ 65

4.1.2 Water Quality. . . . . . . . . . . . . 66

4.1.2.1 Surface water ........... . 66

4.1.2.2 Groundwater ............ . 67

4.1.3 Air Quality and Noise............... 68

4.1.4 Ecology ................. 68 
4.1.4.1 ierrestrial biota............ . 68

4.1.4.2 Floodplains and wetlands . . . . . . . 69

4.1.4.3 Aquatic biota . . . . . . . . . . . . . 71

4.1.4.4 Threatened and endangered species . . . . . 71

4.2 NORMAL OPERATION IMPACTS ............. 72

4.2.1 Surface Water Use and Quality . . . . . . . . . . 72

4.2.2 Sludge Impacts. . . . . . . . . . . . . . . 74

4.2.3 Power Demand .................. 75

4.2.4 Air and Noise Impacts . . . . . . . . . . . . . 75

4.2.5 Radiological Impacts .............. . 76

4.2.6 Ecological Effects .............. 79

4.3 SOCIOECONOMIC EFFECTS ................ 79

4.4 EFFECTS ON CULTURAL, HISTORICAL AND ARCHAEOLOGICAL RESOURCES 80

4.5 ABNORMAL EVENTS .................... 81

4.6 IMPACTS OF DECOMMISSIONING . . . . . . . . . . . . 83

4.6.1 Nonradiological Effects . . . . . . . . . . 83

4.6.2 Radiological Effects ............ 84

4.7 SUMMARY .................. . . . 85

REFERENCES ............................... 89

LIST OF PREPARERS . . . . . . . . . . . . . . . 95

Appendix A: PROGRAMMATIC AGREEMENT REGARDING CULTURAL RESOURCES AT ANL'S ADVANCED PHOTON SOURCE SITE, AND ATTENDANT

CORRESPONDENCE BETWEEN THE ILLINOIS HISTORIC PRESERVATION AGENCY AND THE U.S. DEPARTMENT OF ENERGY

Appendix B: WETLANDS PERMIT AND ATTENDANT CORRESPONDENCE

AMONG THE U.S. ARMY CORPS OF ENGINEERS, THE ILLINOIS

ENVIRONMENTAL PROTECTION AGENCY, THE U.S. DEPARTMENT OF ENERGY, AND ARGONNE NATIONAL LABORATORY

Appendix C: CORRESPONDENCE REGARDING THREATENED AND ENDANGERED SPECIES AMONG THE FISH AND WILDLIFE SERVICE, THE ILLINOIS

DEPARTMENT OF CONSERVATION, AND THE U.S. DEPARTMENT OF ENERGY

Appendix D: AGENCIES AND PERSONS CONSULTED 


\section{LIST OF FIGURES}

Fiqure

Page

1.2.1 Map of Chicago, Illinois, suburbs showing the locations of

ANL, Midway Airport, important roads and waterways . . . . . 3

1.3.1 Vicinity map showing proposed location of Advanced Photon

Source with respect to Argonne National Laboratory . . . . . 5

1.3.2 The APS project and surrounding areas . . . . . . . . . . 6

2.1.1 Advanced Photon Source project site plan . . . . . . . 10

3.1.1 Historic and wetland sites . . . . . . . . . . . 26

3.2.1 Air monitoring locations at and surrounding ANL . . . . . 30

3.4.1 Prehistoric and historic resources in the APS site, and survey methods used ................. 37

3.5.1 Soil types of the ANL site... . . . . . . . . . . . 42

3.6.1 Locations of NPDES discharge monitoring points and water supply wells at ANL.................. 44

3.8.1 Floodplains and wetlands on the APS site. . . . . . . . 54 


\section{LIST OF TABLES}

Table

Page

2.1.1 Site utility services and estimated APS usage . . . . . . 13

2.2.1 APS site-selection evaluation ................ 24

3.2.1 Summary of national and Illinois ambient air quality standards .....................

3.2.2 Total suspended particulates from monitors located within an approximate $16-\mathrm{km}$ radius of $\mathrm{ANL} . . . . . . . . .$. .

3.3.1 Incremental population data in the vicinity of ANL, 1981 . .

3.5.1 Soil types in the vicinity of the APS site . . . . . .

3.6.1 Sawmill Creek--effect of sanitary waste, 1987 . . . . . . . 46

3.6.2 Chemical constituents in Sawmill Creek location 7m, 1987..

3.7.1 Inorganic and radioactive constituents in domestic water, 1987, for ANL Wells 1-4 compared to NIPDWS .......

3.8.1 Wetland type, size, and functional importance in the APS project area and vicinity ................

3.9.1 Environmental penetrating radiation at off-site 


\section{LIST OF ABBREVIATIONS AND ACRONYMS}

ACHP

ANL

APS

BNL

BOD

$B P$

CE

CEQ

CERCLA

COE

DOE

DOE/BES

DOE - $\mathrm{CH}$

DOT

EA

EIS

EPA

ESAAB

ESHD

FWS

GeV

ID

IDC

IEPA

IHPA

$\mathrm{KeV}$

$m A$

Mgd

MIT

NEPA

NESHAP
Advisory Council on Historic Preservation

Argonne National Laboratory

(7-GeV) Advanced Photon Source

Brookhaven National Laboratory

biological oxygen demand

before present (in archaeology)

Commonwealth Edison (Company)

Council on Environmental Quality

Comprehensive Environmental Response, Compensation, and Liability Act (Superfund)

(U.S. Army) Corps of Engineers

(U.S.) Department of Energy

(U.S.) Department of Energy, Office of Basic Energy Sciences

DOE, Chicago Operations Office

(U.S.) Department of Transportation

environmental assessment

environmental impact statement

(U.S.) Environmental Protection Agency

Energy Systems Acquisition Advisory Board

Environment Safety and Health Department (at ANL)

(U.S.) Fish and Wildlife Service

gigaelectron volt ( $10^{9}$ electron volts)

insertion device: wiggler or undulator in a storage ring

Illinois Department of Conservation

Illinois Environmental Protection Agency

Illinois Historic Preservation Agency

kiloelectron volt ( $10^{3}$ electron volts)

milliampere $\left(10^{-3} \mathrm{~A}\right)$

Million gallons per day

Massachusetts Institute of Technology

National Environmental Policy Act

National Emission Standards for Hazardous Air Pollutants 


$\begin{array}{ll}\text { NIPDWS } & \text { National Interim Primary Drinking Water Standards } \\ \text { NOAA } & \text { National Oceanic and Atmospheric Administration } \\ \text { NO }_{x} & \text { nitrogen oxides } \\ \text { NPDES } & \text { National Pollutant Discharge Elimination System } \\ \text { NRHP } & \text { National Register of Historic Places } \\ \text { NSLS } & \text { National Synchrotron Light Source (at BNL) } \\ \text { ORNL } & \text { Oak Ridge National Laboratory } \\ \text { R\&D } & \text { research and development } \\ \text { RCRA } & \text { Resource Conservation and Recovery Act } \\ \text { SHPO } & \text { State Historic Preservation Officer } \\ \text { SMSA } & \text { Standard Metropolitan Statistical Area (Chicago, I1I.) } \\ \text { TDS } & \text { total dissolved solids } \\ \text { TLD } & \text { thermoluminescent dosimeter } \\ \text { TSP } & \text { total suspended particulates } \\ \text { TSS } & \text { total suspended solids } \\ \text { USDA } & \text { (U.S.) Department of Agriculture } \\ \text { ZGS } & \text { Zero Gradient Synchrotron }\end{array}$




\section{CHAPTER 1}

\section{INTRODUCTION}

This environmental asressment (EA) evaluates the potential consequences to the environment of the construction and operation of the proposed 7-GeV synchrotron radiation source known as the 7-GeV Advanced Photon Source (APS) at Argonne National Laboratory (ANL) in Argonne, I1linois. Decommissioning of this facility is also assessed, in general, in order to evaluate the potential magnitude of environmental concerns due to such an action.

\subsection{PURPOSE}

The purpose of the APS project is to construct and operate a major national user facility, providing high-brilliance $X$ rays for users from industry, universities, and national laboratories. The APS project would use recently developed technology to produce beams of high-energy $x$ rays 10,000 times brighter than is currently possible. The bright radiation beams are produced by accelerating positrons (particles like electrons, but positively charged) in a circular path at speeds near that of light. When the beam is bent by magnets, it emits energy in the form of $x$ rays. Insertion devices (IDs) called undulators and wigglers would vibrate the positrons many times, resulting in brilliant beams of $X$ rays (covering the range from 1 to $200 \mathrm{keV}$ ). As many as 70 X-ray beams would be available for research, of which 35 would be from insertion devices providing unprecedented capabilities for research in the nation. Operation of the APS would provide a needed national user facility for cutting-edge research in many fields of science and technology, 
including physics, chemistry, biology, materials sciences, medicine, biotechnology, and the geosciences.

\subsection{THE APS PROJECT AT ANL}

Early in the planning process, the Energy Systems Acquisition Advisory Board (ESAAB) considered a number of DOE national laboratory sites and universities (ANL, Brookhaven National Laboratory (BNL), Stanford University, Stanford Linear Accelerator Center, etc.). On January 22, 1986, the Under Secretary of the U.S. Department of Energy (DOE) determined that planning for four proposed Energy Research projects should proceed at specific DOE laboratories. This senior management site decision was based on the need to maintain the technical viability of the various laboratories. As part of this decision, ANL was identified as DOE's preferred location for the proposed APS.

The ANL site has adequate vacant land to accommodate the 70 acre 1 and requirement for the APS facility and further expansion. In addition, ANL has an extensive history in energy research and has an existing professional and scientific staff of approximately 1500 people with existing offices and laboratory buildings. Furthermore, ANL is located 25 miles southwest of

Chicago (Fig. 1.2.1) and is near major transportation facilities (e.g., 0'Hare International Airport), availability of electrical power, and major universities with materials research laboratories (e.g., University of Chicago and Northwestern).

A Biomedical X-Ray Complex which consists of three beam lines is a possible addition to the APS facility for future construction (1987b). Two beam lines would be used for basic research in determining the crystal structure of proteins, and one beamline would be used for basic research in medical imaging of soft tissue such as coronary structures. Further National 


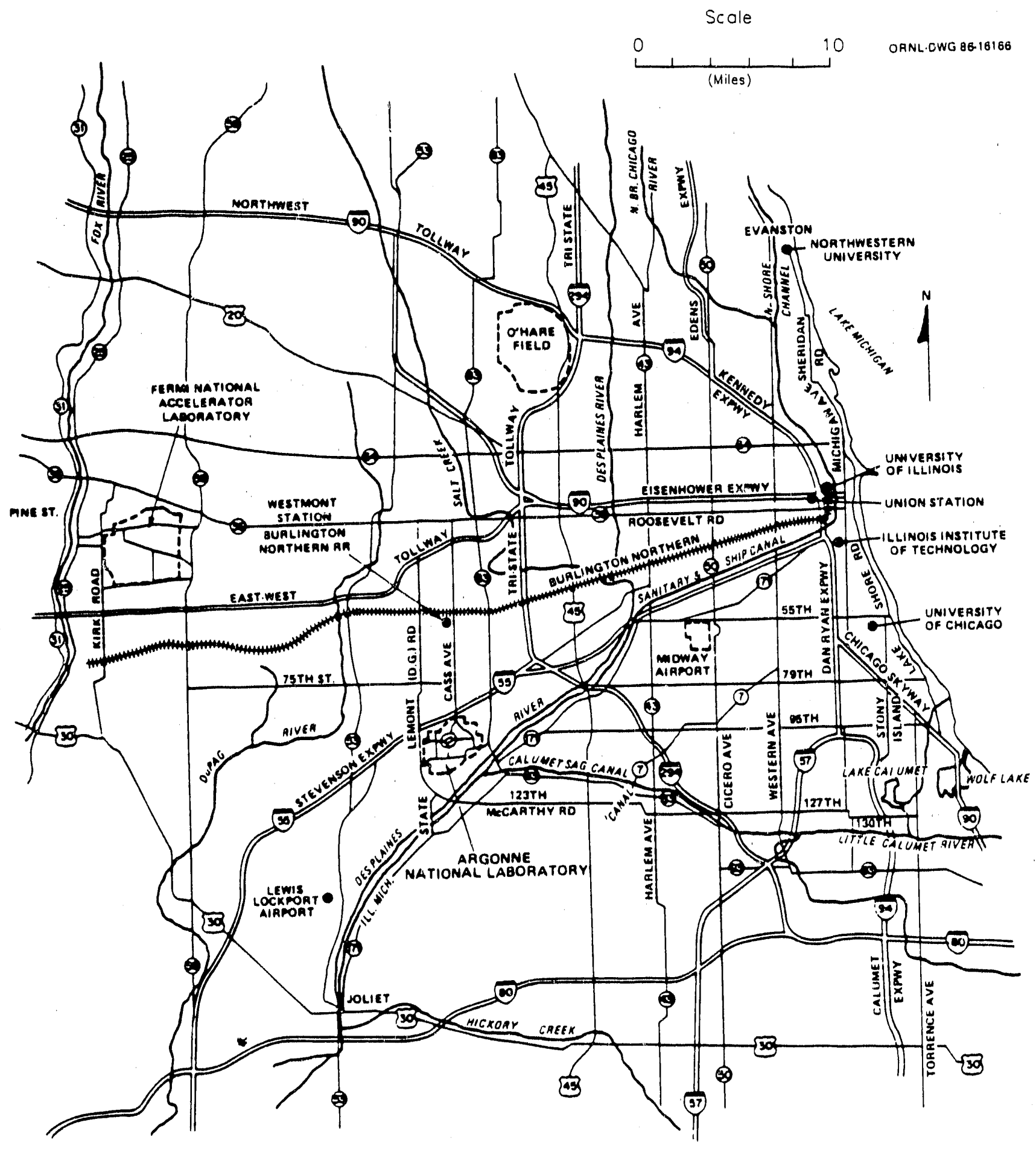

Fig. 1.2.1. Map of Chicago, Illinois, surburbs showing the locations of ANL, Midway Airport, important roads and waterways. 
Environmental Policy Act (NEPA) documentation will be required if the Biomedical X-Ray Complex is proposed for construction in the future.

\subsection{SUMMARY OF THE PROPOSED ACTION}

The proposed action is the construction and subsequent operation of the APS. This project would occupy 28 ha (70 acres) of fields and forest in the southwest portion of the 516-ha (1275-acre) ANL property (Fig. 1.3.1). The APS is a storage ring, where a $100-\mathrm{mA}$ beam of positrons (i.e., positively charged electrons) circulates continuously at an energy of about $7 \mathrm{GeV}$ (ANL 1987a). Figure 1.3.2 shows the storage ring, and the ANL area that surrounds APS. The biomedical beam line has been proposed as an optional addition to the APS facility (ANL 1987b).

\subsection{NEED FOR ACTION}

During the past two decades, synchrotron radiation from high-velocity. electrons or positrons traveling in roughly circular paths has become the most important source of high-intensity photon beams useful for research. Such photon sources have emerged as powerful and versatile tools for examining the geometric and electronic structure of matter. The intensity, tunability, collimation, and high degree of polarization characteristic of such photon sources vastly exceed those of conventional sources. In the United States, there are seven synchrotron radiation facilities of different designs and characteristics now in operation, including recent additions at the National Synchrotron Light Source (NSLS) at BNL. Outside the United States, there are now 30 synchrotron sources operating or under construction.

Initially, high-energy physics accelerators provided synchrotron radiatiun from the bending magnets that function to keep the electron beam in 


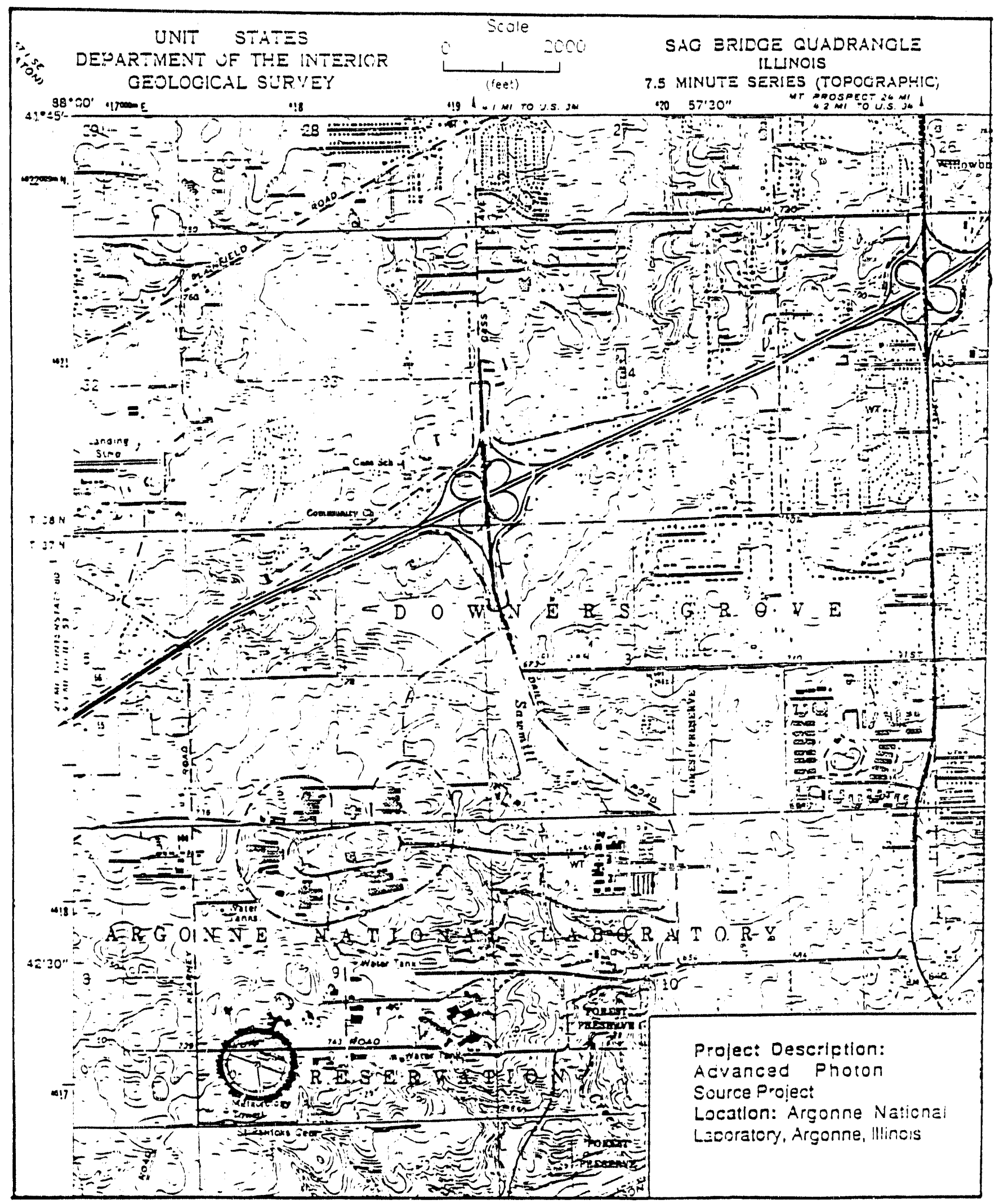

Fig. 1.3.1. Vicinity map showing proposed location of Advanced Photon Source with respect to Argonne Natiorial Laboratory. 


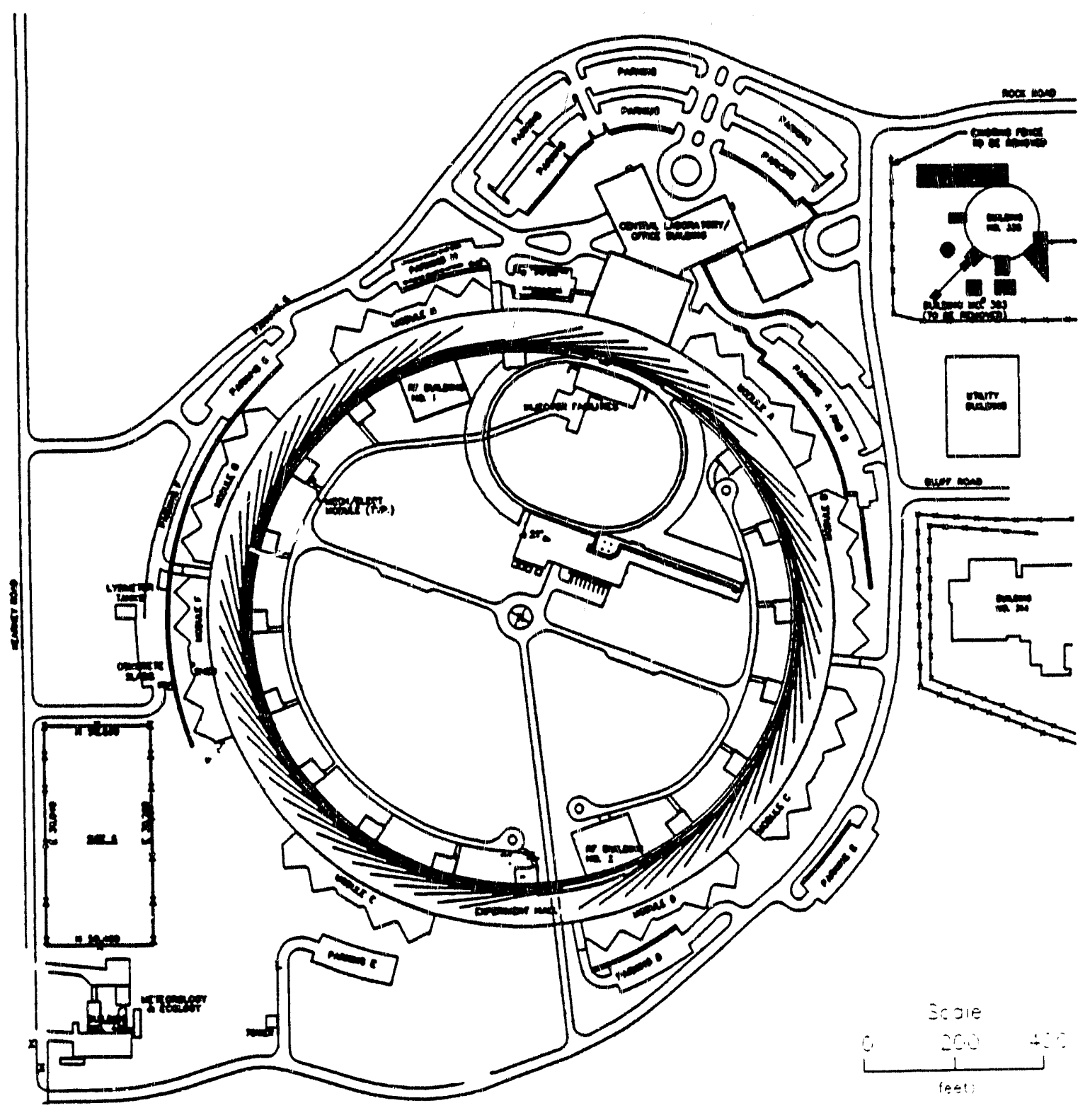

Fig. 1.3.2. The APS project and surrounding areas. 
a circular path within the accelerator. As research with such sources progressed, it was recognized that the brilliance (i.e., the number of photons per specified wavelength bandwidth per second per unit solid angle per unit area of source) of the emerging radiation could be greatly increased by the use of specially designed magnets inserted into the straight sections of an accelerator or storage ring. Such devices, or IDs, composed of periodic arrays of magnets placed above and below the path of the electron beam, are now successfully used as high-intensity photon sources at several accelerators around the world.

Recognizing the scientific and technological implications of the extremely brilliant beams that could be obtained from IDS, the U.S. synchrotron radiation community began to consider construction of storage rings optimized for IDs. Interest increased, as demand began to exceed the availability of existing sources, prompting DOE to conclude that a detailed examination of U.S. synchrotron radiation research requirements was needed.

In October 1983, a committee was convened by the DOE Office of Basic Energy Sciences (DOE/BES) to evaluate future opportunities and technical needs for synchrotron-radiation based research. This 17 -member committee concluded that the highest-priority major new facility should be a high-energy storage ring optimized for IDs capable of providing $X$ rays of energy up to $20 \mathrm{keV}$ and targeted for operation by the early 1990s. Such a storage ring requires a minimum electron or positron beam energy of about $6 \mathrm{GeV}$ and a capability of accommodating a large number of IDs (Eisenberger and Knotek 1984).

Shortly after the Eisenberger-Knotek Committee report was issued, the National Academy of Sciences organized a comprehensive study of major facilities needed for materials science research. This committee, chaired by 
Fredrick Seitz and Dean Eastman, concluded that the highest-priority major new facility should be a $6-\mathrm{GeV}$ ID-based synchrotron source. Subsequently, DOE asked the Energy Research Advisory Board to evaluate the conclusions of the Seitz-Eastman report in terms of DOE programs and responsibilities. The board strongly endorsed the priorities established by the Seitz-Eastman report (Seitz-Eastman 1984) as being consistent with the needs of DOE and in the best interests of the nation (DOE 1985). 


\section{CHAPTER 2}

\section{THE PROPOSED ACTION AND ALTERNATIVES}

\subsection{DESCRIPTION OF APS AND CONSTRUCTION ACTIVITIES (PROPOSED ACTION) \\ 2.1.1 APS Facility Description}

The proposed action is the construction and operation of an Advanced Photon Source national user facility that provides high-brilliance $X$ rays for users from industry, universities, and national laboratories.

APS would consist of a large storage ring containing as many as 34 IDs (wigglers and undulators) to give intense, hard $X$ rays. The storage ring has a circumference of approximately $1104 \mathrm{~m}$ ( $0.7 \mathrm{miles})$ and is capable of accommodating 34 IDs and their associated photon beam 1 ines. In addition, 35 photon beains can be provided from bending magnets (ANL 1987a). The experimental area, which houses the beam lines, is large enough to accommodite beam lengths up to $80 \mathrm{~m}(264 \mathrm{ft})$ within the Experiment Hall. Building design allows extension of the beam lines through the external wall of the Experiment $\mathrm{Ha} 11$.

The principal building of the facility is an annular structure having an outer circumference of $1244 \mathrm{~m}(4083 \mathrm{ft})$ and a width of $27 \mathrm{~m}(88 \mathrm{ft})$. This building and its associated support and service huildings are all conventional metal structures. Figure 2.1.1 shows the APS site plan with the storage ring, the linear accelerator (linac), and the synchrotron. The linsar accelerator injects the positrons into the synchrotron, which accelerates them to $7 \mathrm{GeV}$ for injection into the storage ring. A current of approximately $100 \mathrm{~mA}$ of 6- to 7-GeV positrons circulates in the storage ring (AN! 1987a). Figure 2.1.1 also shows the central 1ab/office building, lab/office modules, 


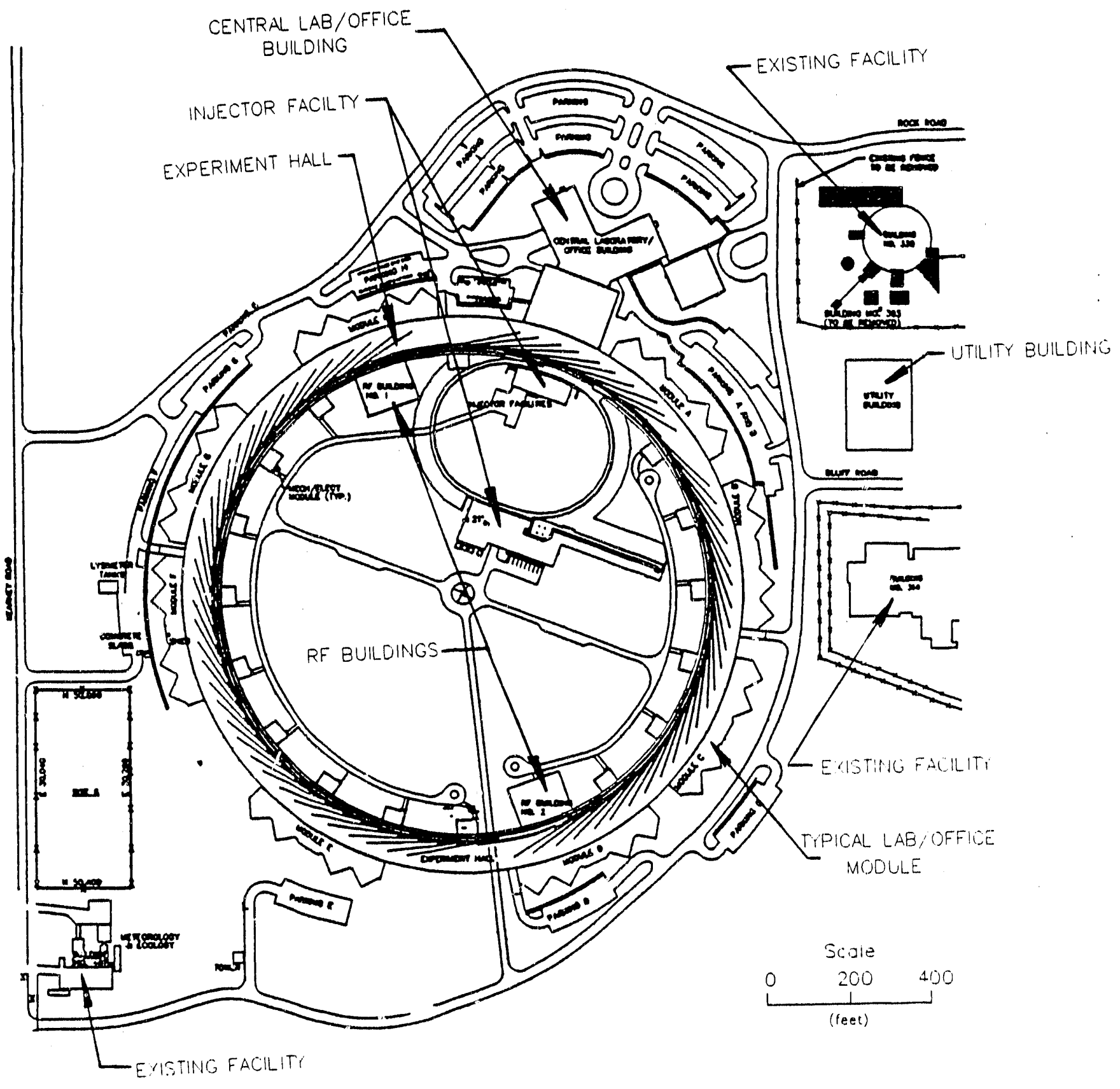

Fig. 2.1.1. Advanced Photon Source Project site plan. 
Experiment Hall where X-ray beams would be used for research and development (R\&D) experiments, site access roads, and miscellaneous site amenities. The APS facilities are designed to accommodate 600 permanent and temporary personne1.

Project Center (Central Laboratory/Office Building): a conventionally designed multistory building that would house 300 permanent staff scientists and support personnel. It would contain laboratories (for light use with nontoxic substances), offices, library, meeting facilities, control room for remote control of APS, technical area for assembly of experimental equipment, stock room, machine shop, truck airlock, clean rooms, and a mechanical room for air conditioning and service utility equipment.

Experiment Hall/Storage Ring Building: an annular steel-framed, metal-clad building. The interior area is dedicated to experimental beam lines. A concrete storage ring enclosure is located within the building near the inner wal1. The $x$-ray beams are extracted from the storage ring into the experimental beam lines.

Synchrotron Buildings: four contiguous conventional metal buildings housing the synchrotron injection/extraction facilities and the synchrotron ring enclosure. The linear accelerator and the synchrotron ring are concrete tunnel structures covered with earth for radiation shielding.

Service Buildings: metal-framed buildings located within the infield of the Experiment Hall/Storage Ring Building that house storage-ring magnet power supplies, radio-frequency equipment, and electrical substations.

Laboratory/Office Modules: four metal-framed structures located around the outer wall of the Experiment Hall/Storage Ring Building. They contain offices, laboratories, a conference area, and service support space. A parking area for each module is also provided. 
Utility Building: a single-story, metal-framed structure that contains the mechanical and electrical equipment support for APS. The cooling tower yard is located immediately adjacent to the building.

Site Improvement: several roads to provide access to all APS areas from the existing ANL road system. The site would be graded and landscaped with provisions for storm-water runoff (Pentecost 1987).

\subsubsection{Utility Services}

All service utilities exist at intercept points near the proposed APS complex. Table 2.1.1 lists the expected demands on utilities resulting from operation of APS relative to excess capacities (Kolzow 1988).

The operation of an APS requires a large amount of power (23 MVA average, with a peak demand of $34 \mathrm{MVA})$. Electrical service to ANL is provided by two independent 138-kV distribution circuits from Commonwealth Edison Company. Two 13-kV feeder circuits that originally serviced the ANL Zero Gradient Synchrotron (ZGS) accelerator facility (shut down in 1979) would provide power to APS from an existing substation. No new off-site power lines would be needed.

New mechanical-draft recirculating-type cooling towers would be constructed and located immediately east of the APS project site (Pentecost 1986). The towers are expected to supply between 2000 tons (winter) and 5000 tons (summer) of refrigeration. Cooling water demands are based on a usage of $3 \mathrm{gal} /(\mathrm{min} \cdot \mathrm{ton})$ of refrigeration; therefore, APS peak usage is estimated at $56,800 \mathrm{~L} / \mathrm{min}(15,000 \mathrm{gal} / \mathrm{min})$. One percent would be 1 ost to evaporation [568-L/min (150-gal/min) peak]. The blowdown rate is seasonally dependent, with $380-680 \mathrm{~L} / \mathrm{min}(100-180 \mathrm{gal} / \mathrm{min})$ or 2000 tons of refrigeration required during the winter months and 1140-1890 L/min (300-500 gal/min) or 
Table 2.1.1 Site utility services and estimated APS usage (Pentecost 1987).

\begin{tabular}{|c|c|c|c|c|c|}
\hline Utility & Inits & $\begin{array}{c}\text { Current } \\
\text { lab-wide use }\end{array}$ & $\begin{array}{l}\text { Estimated } \\
\text { APS use }\end{array}$ & $\begin{array}{l}\text { Projected } \\
\text { lab-wide use }\end{array}$ & $\begin{array}{l}\text { Projected } \\
\text { APS use (relative } \\
\text { to excess ANL } \\
\text { capacity) }\end{array}$ \\
\hline \multicolumn{6}{|l|}{ Steam: } \\
\hline $\begin{array}{l}\text { Installed capacity } \\
\text { Peak demand } \\
\text { Average usage } \\
\text { Annual usage }\end{array}$ & $\begin{array}{ll}10^{3} & 1 \mathrm{~b} / \mathrm{h} \\
10^{3} & 1 \mathrm{~b} / \mathrm{h} \\
10^{3} & 1 \mathrm{~b} / \mathrm{h} \\
10^{6} & 1 \mathrm{~b}\end{array}$ & $\begin{array}{r}360 \\
224 \\
99 \\
870\end{array}$ & $\begin{array}{r}50 \\
40 \\
9 \\
80\end{array}$ & $\begin{array}{l}264 \\
108 \\
950\end{array}$ & $\begin{array}{r}29 \% \\
3 \%\end{array}$ \\
\hline \multicolumn{6}{|l|}{ Electricity: } \\
\hline $\begin{array}{l}\text { Installed capacity } \\
\text { Peak demand } \\
\text { Average usage } \\
\text { Annual usage }\end{array}$ & $\begin{array}{l}\text { MVA } \\
\text { MVA } \\
\text { MVA } \\
\text { MWH }\end{array}$ & $\begin{array}{r}136 \\
23 \\
15 \\
132,000\end{array}$ & $\begin{array}{r}47 \\
34 \\
23 \\
198,000\end{array}$ & $\begin{array}{r}57 \\
38 \\
330,000\end{array}$ & $\begin{array}{l}30 \% \\
19 \%\end{array}$ \\
\hline \multicolumn{6}{|l|}{ Domest ic Water: $b$} \\
\hline $\begin{array}{l}\text { Installed capacity } \\
\text { Peak demand } \\
\text { Average usage } \\
\text { Annual usage }\end{array}$ & $\begin{array}{l}\mathrm{Mg} \\
\mathrm{Mg} \\
\mathrm{Mg} \\
\mathrm{Mg}\end{array}$ & $\begin{aligned} & 1.2 \\
& 1.6 \mathrm{C} \\
& 0.4 \\
& 152.4\end{aligned}$ & $\begin{array}{r}0.03 \\
0.03 \\
0.03 \\
10.95\end{array}$ & $\begin{array}{r}1.63 \\
0.43 \\
163.35\end{array}$ & $\begin{array}{l}3 \% \\
4 \%\end{array}$ \\
\hline \multicolumn{6}{|l|}{ Canal Water: } \\
\hline $\begin{array}{l}\text { Installed capacity } \\
\text { Peak demand } \\
\text { Average usage } \\
\text { Annual usage }\end{array}$ & 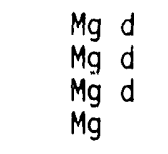 & $\begin{array}{r}4.0 \\
0.5 \\
0.3 \\
97.4\end{array}$ & $\begin{array}{r}0.7 \\
0.5 \\
0.4 \\
146\end{array}$ & $\begin{array}{r}1.0 \\
0.7 \\
243.4\end{array}$ & $\begin{array}{l}14 \% \\
11 \%\end{array}$ \\
\hline \multicolumn{6}{|l|}{ Lab Water: ${ }^{b}$} \\
\hline $\begin{array}{l}\text { Installed capacity } \\
\text { Peak demand } \\
\text { Average usage } \\
\text { Annual usage }\end{array}$ & $\begin{array}{l}M g d \\
M g, d \\
M g d \\
M g\end{array}$ & $\begin{array}{l}0.8 \\
1.0 \mathrm{~d} \\
0.3 \\
92.8\end{array}$ & $\begin{array}{r}0.05 \\
0.05 \\
0.05 \\
18.25\end{array}$ & $\begin{array}{r}1.05 \\
0.35 \\
111.05\end{array}$ & $\begin{array}{l}25 \% \\
10 \%\end{array}$ \\
\hline \multicolumn{6}{|l|}{ Lab Sewer: } \\
\hline $\begin{array}{l}\text { Installed capacity } \\
\text { Peak demand } \\
\text { Average usage } \\
\text { Annual usage }\end{array}$ & 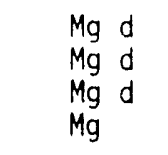 & $\begin{array}{l}0.77 \\
0.63 \\
0.4 \\
140\end{array}$ & $\begin{array}{r}0.05 \\
0.05 \\
0.05 \\
18.25\end{array}$ & $\begin{array}{r}0.68 \\
0.45 \\
158.25\end{array}$ & $\begin{array}{l}36 \% \\
14 \%\end{array}$ \\
\hline \multicolumn{6}{|l|}{ Sanitary Sewer: } \\
\hline $\begin{array}{l}\text { Installed capacity } \\
\text { Peak demand } \\
\text { Average usage } \\
\text { Annual usage }\end{array}$ & $\begin{array}{ll}M g & d \\
M g & d \\
M g & d \\
M g & \end{array}$ & $\begin{array}{c}1.26 \\
0.70 \\
0.4 \\
130\end{array}$ & $\begin{array}{r}0.03 \\
0.03 \\
0.03 \\
10.95\end{array}$ & $\begin{array}{r}0.73 \\
0.43 \\
140.95\end{array}$ & $\begin{array}{l}5 \% \\
3 \%\end{array}$ \\
\hline
\end{tabular}

axcess capacity = Installed capacity - current lab-wide use.

bomestic and 1 ab water installed capacity and peak demand based upon treatment capacity. The FY 86 Schedule 44 addresses pumping capacity.

CPeak demand met by treated domestic water storage capacity of 1,275,000 gallons.

dpeak demand met by treated lab water storage capacity of 400,000 gallons. 
5000 tons of refrigeration required during the summer months. The ANL cooling water is obtained from the Chicago Sanitary and Ship Canal (Fig. 1.2.1) and is treated by adding alum and a polymer to remove turbidity from the canal water. The treated water is chlorinated, and additional corrosion inhibitor (phosphate-based) and biocide (e.g., chlorine) may be added to the cooling towers. No withdrawal permit is required for water pumped from the canal.

The APS cooling water treatment process would generate $95-115 \mathrm{~m}^{3}$ (125-150 cubic yards) of sludge per year. The sludge would be disposed of in the ANL landfill an average of once every eight months. This increase [from the current $76 \mathrm{~m}^{3}$ (100 cubic yards) per year] represents a $0.5 \%$ increase in the ANL landfil1 permitted limit of $22,900 \mathrm{~m}^{3}(30,000$ cubic yards) per year. A11 cooling water would be disposed of through the ANL sanitary sewer system.

Table 2.1.1 lists predicted APS utility demands compared with total ANL demands and excess capacities. The table shows that estimated average APS uses of electrical power and canal cooling water would result in laboratorywide increases of 19 and $11 \%$, respectively, of the excess capacities for these utilities-121 MVA and $14,000 \mathrm{~m}^{3} / \mathrm{d}$ [3.7 million gallons per day (Mgd)]. Table 2.1.1 shows that predicted demand increases for steam, sewer, and domestic and laboratory water attributable to APS range only from 3 to $36 \%$ of excess capacity.

\subsubsection{Gaseous Emissions, Liquid Effluents, and Wastes}

The operation of APS would generate some emissions, effluents, and wastes, such as normal plant/vehicular heat radiation, cooling-tower plumes, and storm-water runoff. APS construction plans include the use of holding ponds for storm-water runoff based on final contour configurations 
(Pentecost 1987, ANL 1987a). There also would be potential contaminants from experimental sources which may include trace amounts of organic solvents, toxic proteins (48- to 72 -h shelf life), microbiological products (treatable with micro-biocides), heavy metal compounds, and small amounts of carcinogenic waste. No radioactive waste is expected to be produced as a result of normal facility operations. The contaminant groups would be carefully controlled, and the wastes would be collected in special containers for disposal in accordance with waste management procedures developed to ensure compliance with DOE and ANL Resource Conservation and Recovery Act (RCRA) permits (Cheever 1986).

During operation of the APS, there would be normal positron beam losses within the aluminum vacuum chamber walls, producing energetic photons and some energetic secondary neutrons. These neutrons are capable of activating the air and some accelerator components (e.g., magnets) inside the accelerator shielding enclosure. Typical products in the air are carbon-11 (half-life = $20 \mathrm{~min}$ ), nitrogen-13 (half-life $=10 \mathrm{~min}$ ), and oxygen-15 (half-life $=122 \mathrm{~s}$ ). These would be exhausted from the accelerator shielding enclosure at a rate of $1,835,000 \mathrm{~L} / \mathrm{min}(64,000 \mathrm{cfm})$ under normal operations (an annual operating duration of 8,000 hours and $10 \%$ of this time for the Injector system). This would result in a production rate of activated air species of about 350 $\mathrm{nC} \mathrm{i} /\left(\mathrm{m}^{3} \mathrm{~d}\right)$ (Cho 1989a). Similar activation products can also be produced in the water circulated in a closed system to cool the accelerator components. However, the production rate in water would be at least an order of magnitude lower than in air (Swanson 1979).

Small amounts of induced activity would also occur in the accelerator components distributed around the $1104 \mathrm{~m}(0.7 \mathrm{mile})$ circumference of the accelerator. Lead, concrete, and aluminum are least susceptible to 
activation, while copper and iron are slightly more susceptible (Swanson 1979). Calculations indicate that most of this induced activity would be generated in the iron of the magnets. A saturation activity of about 13 $\mathrm{pCl} / \mathrm{cm}^{3}$ would result (Huebner 1988b). These induced activities (i.e., Mn-56, Mn-52, Cr-51, V-48, Fe-59, etc.) have short half-lives that range from a few hours to less than one year and are fixed in the accelerator components.

The only other effluent would be blowdown water [expected to be 380-680 $\mathrm{L} / \mathrm{min}(100-180 \mathrm{gal} / \mathrm{min})$ in winter and $1140-1840 \mathrm{~L} / \mathrm{min}(300-500 \mathrm{gal} / \mathrm{min})$ in summer] discharged from the cooling system into the sanitary sewer system and discharged after treatment, through ANL's National Pollutant Discharge Elimination System (NPDES) Outfall 001. This water effluent would not contain any process liquids. It would contain phosphate-based corrosion inhibitors and biocide (e.g., chlorine) similar to those currently in use at other ANL cooling systems. The temperature of the cooling water discharged to the sanitary sewer system would range from $16^{\circ} \mathrm{C}\left(60^{\circ} \mathrm{F}\right)$ (winter) to $35^{\circ} \mathrm{C}\left(95^{\circ} \mathrm{F}\right.$ ) (summer).

\subsubsection{Construction Activities}

Construction of APS at the ANL site would require a number of different actions (ANL 1987a): (1) preparation of the site (i.e., grading, excavation, and provision of drainage, construction roads, walkways and parking areas); (2) extension of existing utilities (i.e., electrical power, water, sewage, gas, and communications); (3) construction of APS proper (1 inear accelerator, synchrotron, storage ring) and APS facilities; and (4) completion of the project (backfill and landscaping).

The proposed site is located on 28 ha (70 acres) of field and forest in the southwest portion of ANL (see Sect. 3.1). The site would be cleared and 
stripped of about $51,200 \mathrm{~m}^{3}\left(66,900\right.$ cubic yards) of topsoil and $87,300 \mathrm{~m}^{3}$ $(114,200$ cubic yards) of unclassified soil. These excavations would be stockpiled for respreading and fill later in construction. Excess soil [about $27,200 \mathrm{~m}^{3}(35,600$ cubic yards $\left.)\right]$ would be moved to disposal sites on ANL property (Title I 1989).

Because positron beam alignment is a basic concern for this facility, it is essential that its concrete foundation slab be set level, with only minimal settlement. Thus, the building excavation would extend to a depth adequate to allow most of the Experiment Hall floor slab to rest on undisturbed soil. The Experiment Hall would be constructed on concrete caissons, or spread footings, which would not penetrate the underlying aquifer. Any existing unstable areas under the Experiment Hall would be backfilled with engineered structural fill to prevent settlement. Where fill was required, the existing ground would be removed to a minimum depth of $0.6 \mathrm{~m}(2 \mathrm{ft})$ and replaced by cohesionless, wellcompacted backfill. All of the construction associated with earthwork would use methods that minimize soil erosion (ANL 1987a).

Approximately $21,500 \mathrm{~m}^{3}(17.4 \mathrm{acre}-\mathrm{ft})$ of storm-water storage would be provided in general locations around APS to meet local storm-water detention provisions (ANL 1987). The total allowable release from the site is approximately $221 \mathrm{~L} / \mathrm{s}\left(7.8 \mathrm{ft}^{3} / \mathrm{s}\right)$.

The proposed APS site is divided into a north and a south section by an east-to-west drainage divide. Therefore, a storage of $8,264 \mathrm{~m}^{3}(6.7 \mathrm{acre}-\mathrm{ft})$ would be provided on either side of the site. The detention basins would be self draining and sized to drain in less than 72 hours.

Storm water collected on the APS site would be conveyed to the detention basins in properly sized storm sewers or ditches. Storm-water runoff from the buildings, roadways, parking areas, and the infield area would be conveyed to 
the outlet sewers via ditches or small storm sewers. A drain system around building foundations would also drain to the outlet sewers (ANL 1987a).

No details are available at this time about construction schedule and equipment to be used in each construction phase. However, construction of APS would proceed in a routine fashion, following well established practices. A worst-day construction scenario involving the following activities and equipment is assumed:

a. The construction would disturb approximately 28 ha (70 acres) of land. Site clearing would take place over a period of 30 days, involving considerable amounts of excavating and grading.

b. The vehicles to be used in the construction would include two bulldozers, five 20 -ton trusks capable of transporting $15 \mathrm{~m}^{3}$ (20 cubic yards) each, two one-half-ton pickup trucks for construction engineers, and one water truck to water the construction site and dusty roads to minimize fugitive dust.

c. About $138,500 \mathrm{~m}^{3}(181,100$ cubic yards) would be sent to two locations. About $111,300 \mathrm{~m}^{3}(145,500$ cubic yards) would be kept on the site for later landscaping. The remainder of the soil would be deposited in berms on the ANL site. Clay soil would be used as cover material on the 800 Area Sanitary Landfill.

d. There would be one drilling rig at the site to drill and place 240 caissons of $0.8-\mathrm{m}(2.6-\mathrm{ft})$ diameter to a depth of $12 \mathrm{~m}$ $(39 \mathrm{ft})$. The drilling rig probably would not be present during the pretiminary site clearing.

In addition to this construction equipment, about 100 automobiles are expected to arrive daily with workers during the peak construction period. The cars would arrive by $6: 30 \mathrm{a} . \mathrm{m}$. and would depart at about 3:30 p.m. each 
day. Approximately one-half of these would be expected to leave and return during the lunch period. It is anticipated that most of the traffic would use Kearney Road and the Westgate entrance. Bluff Road would remain open during the first phase of the construction to permit easy access of cars and construction vehicles to the APS site (Pentecost 1986).

\subsubsection{Decommissioning}

It is difficult to estimate the useful lifetime of the APS before decommissioning because (1) the degree and duration of future user demand for continuing scientific-research use of the facility is unknown and (2) future development of accelerator and ID technology may enable this facility to evolve into a next-generation synchrotron radiation source, thereby extending its useful lifetime for research.

Nevertheless, it is worthwhile to consider decommissioning procedures that might be necessary for the APS $f_{a}$ ility some 20 to 30 years after first operation. During the past 20 years four electron accelerators of energy greater than $1 \mathrm{GeV}$ (Cornell, $1.5 \mathrm{GeV}$; California Institute of Technology, 1.0 Gel; Cornel1, 2.5 GeV; and Harvard/Massachusetts Institute of Technology (MIT), $6 \mathrm{GeV}$ ) have been decommissioned. Decommissioning experience at these and at ANL's 12.5-GeV proton synchrotron provides a relevant experience base to draw upon in developing decommissioning plans for the APS.

Decommissioning of the APS and associated facilities (1) would be similar to other electron (or positron) accelerator/storage ring facilities of comparable energy and design, (2) would present no unique problems, and (3) could be performed using currently available technolrgy. From a radiological perspective, electron accelerators and storage rings are appropriately classified as very low-level facilities and therefore do not 
require unusual or particularly complicated decontamination procedures. Equipment and facilities installed outside of the accelerator shielding enclosures have only a negligible possibility of being activated.

It is anticipated that decommissioning of the accelerator and storage ring facilities would proceed in three phases (Huebner 1988a):

1. Shutdown. After orderly shutdown and disconnection of operating systems, electrical power, and cooling water systems to the accelerator facilities, physical and administrative controls for limiting access to the facilities would be maintained.

2. Survey of residual activities. Every component in the accelerator enclosures would be surveyed by health physics personnel to identify and tag any radioactive components. Based on the documented radiation survey, an inventory of all activated materials and equipment would be made and kept under continued surveillance and maintenance. It is anticipated that all components, except for the positron production target and associated shielding, would be essentially radioactivity free. The volume of activated materials in the positron production target area is estimated to be about $0.5 \mathrm{~m}^{3}$ ( 0.7 cubic yards), composed primarily of steel. The level of activity would depend upon the length of operation, but dose rates are not expected to exceed a few tens of millirem per hour at an $8-\mathrm{cm}(3-\mathrm{in.})$ distance. As a result of this phase, all excess accelerator equipment would be categorized by type and radioactivity level and would be ready for removal. 
3. Removal of components and dismantling. It is anticipated that the inventory would include three general categories of components:

(a) Contamination-free components would be removed to a temporary storage area, possibly a portion of the Experiment Hall.

Experience at decommissioning of other accelerator facilities indicates that magnets, power supplies, and vacuum pumps belong to this category and are reusable at another accelerator facility.

(b) Reusable items with some residual radioactivity would be removed under health physics supervision and stored in a separate radiologically controlled location for future shipment. Packaging and shipment of these items would follow U.S. Department of Transportation (DOT) specifications. For example, the decommissioned electron linac from the Harvard/MIT 6-GeV synchrotron was relocated and is currently used as the injector for the NSLS at BNL.

(c) Nonreusable items with some residual radioactivity would be packaged according to DOT specifications and shipped to a DOEapproved radioactive waste disposal site. For the proposed action, this might involve cutting of large pieces, under health physics supervision, into sizes suitable for shipment. In all cases, radioactive and nonradioactive components would be kept segregated.

Decommissioning of conventional facilities would follow after all activated components are identified and removed. No parts of the building structures or equipment are expected to be activated; therefore, they would be available for reuse. Hardware and equipment installed outside the accelerator enclosure 
would be ward using standard ANL procedures for disposition of excess government properties.

\subsection{ALTERNATIVES}

\subsubsection{No Action}

Taking no action would mean not constructing a $7-\mathrm{GeV}$ synchrotron radiation source and would result in no changes to the existing environment. However, as mentioned in Sect. 1.4, synchrotron radiation has emerged as a powerful tool for probing the structure of matter and studying important physical and chemical processes. Among the scientific advances that would be fostered by using radiation from this storage ring are the determination of bulk and surface structure and of catalytic activity of materials, microprobe impurity detection, inelastic $X$-ray scattering, and observation of the motion of atoms in protein systems.

\subsubsection{Construction at Another ANL Site}

Within ANL, four locations were identified as potentially suitable to meet the space requirements of the APS. These were the East Area, the 300 (ZGS) Area, and the North and South 800 Areas. Site selection is influenced by the following factors: (1) suitability of the site to meet technical requirements of design configuration and functional relationships;

(2) suitability of topography and subsurface conditions; (3) minimal environmental resource impacts; (4) avoidance of external and trafficgenerated sources of vibration; (5) provision of a buffer zone between APS and the ANL site boundary; (6) minimal interference of existing structures; (7) availability of existing utilities; and (8) flexibility of the site for future expansion. The East Area is unacceptable because of its proximity to traffic- 
generated vibration along Cass Avenue, the lack of an adequate buffer zone, and topography and floodplain limitations to the west and south. Limitations of the 300 Area are the sources of vibration, the lack of an adequate buffer zone, and restricted expansion potential because of existing facilities. Therefore, the East Area and the 300 Area were eliminated on the basis of technical considerations.

The proposed location for the APS centered on Bluff Road in the South 800 Area provided the best overall resolution of these factors. Table 2.2.1 qualitatively summarizes these findings. Wetlands and topography limited the possible location of the APS in the North 800 Area. Additional studies justified moving the site south $82 \mathrm{~m}(270 \mathrm{ft})$ and west $30 \mathrm{~m}(100 \mathrm{ft})$, as well as rotating it 21 degrees clockwise. This location moves the facility from the floodplain and wetlands to the north. Site boundaries and the need for a buffer zone restrict moving the facility farther to the south or west. 
Table 2.2.1. APS site-seiection evaluationa

\begin{tabular}{lllll}
\hline Site & East Area & 300 Area & North 800 Area & South 800 Area \\
\hline Design suitability & fair & good & fair & good \\
Topography & fair & good & fair & good \\
Environmental & poor & good & poor & fair \\
Vibration & poor & poor & good & good \\
Buffer zone & poor & poor & good & good \\
Existing structures & good & poor & good & good \\
Utility access & fair & good & good & good \\
Expansion potential & rair & poor & good & good \\
\hline
\end{tabular}

${ }^{\mathrm{a}}$ good $=$ acceptable in all aspects; fair = minimally acceptable, some mitigating action; poor = unacceptable in one or more nonmitigative aspects. 


\section{CHAPTER 3}

\section{THE AFFECTED ENVIRONMENT}

\subsection{SITE DESCRIPTION}

The proposed 28-ha (70-acre) APS site lies on both sides of the existing Bluff Road, just east of Kearney Road on the southwest portion of ANL (Fig. 1.3.2). Figure 3.1 .1 is a map of the APS proposed site with the wetlands and areas of cultural interest identified.

ANL occupies a 516-ha (1275-acre) site of gently rolling 1 and in the Des Plaines River Valley of DuPage County, Illinois, about $35 \mathrm{~km}$ (22 miles) southwest of downtown Chicago and $40 \mathrm{~km}$ (25 miles) west of Lake Michigan. Laboratory facilities occupy about 81 ha (200 acres) of the total ANL site area. Surrounding the ANL site is the 826-ha (2040-acre) Waterfall Glen Forest Preserve, a greenbelt forest preserve of the DuPage County Forest Preserve District. Nearby highways are Interstate 55 to the north and Illinois Highway 83 to the east (Fig. 1.2.1). About $1.6 \mathrm{~km}$ (1 mile) south of ANL are the Des Plaines River, the Chicago Sanitary and Ship Canal, and the Illinois Waterway (Illinois and Michigan Canal). The principal stream on the site is Sawmill Creek, which drains southward to the Des Plaines River. The forest preserve and the area between the river and ANL are undeveloped, whereas urban developments predominate other surrounding areas.

\subsection{CLIMATOLOGY AND AIR QUALITY}

\subsubsection{Climatology}

The regional climate around the APS site is characterized as being continental, with relatively cold winters and hot summers (DOE 1982), and is slightly modified by Lake Michigan (Denmark 1974). 


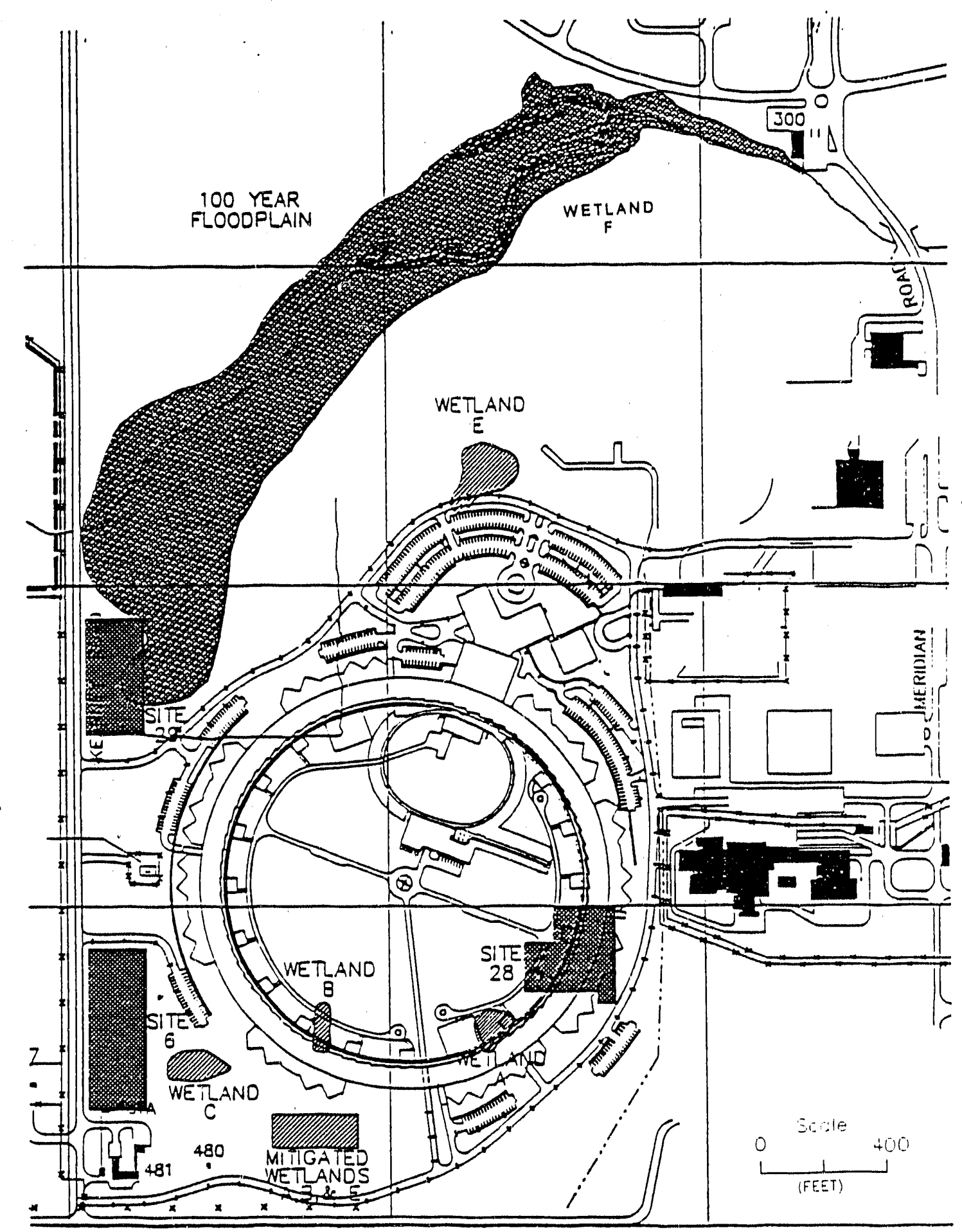

Fig. 3.1.1. Historic and Wetland sites. 
Weather data for the ANL area are presented in detail in ANL's sitewide environmental assessment (DOE 1982). The average daily air temperature at ANL is $8.9^{\circ} \mathrm{C}\left(48^{\circ} \mathrm{F}\right)$. Average diurnal variations of temperature range from $7.6^{\circ} \mathrm{C}$ $\left(13.7^{\circ} \mathrm{F}\right)$ in December to $11.4^{\circ} \mathrm{C}\left(20.5^{\circ} \mathrm{F}\right)$ in May.

The predominant wind direction is from the south, and wind from the southwest quadrant occurs almost $50 \%$ of the time (DOE 1982). The average wind speed at ANL at a height of $5.8 \mathrm{~m}(19 \mathrm{ft})$ is $3.4 \mathrm{~m} / \mathrm{s}(7.6 \mathrm{mph})$, with calm periods occurring $3.1 \%$ of the time.

The average annual precipitation at ANL is $800 \mathrm{~mm}(31.5 \mathrm{in.})$ and is primarily associated with thunderstorm activity in the spring and summer. The annual average accumulation of snow and sleet at ANL is $818 \mathrm{~mm}$ (32.7 in) (DOE 1982). Snowstorms resulting in accumulations greater than $150 \mathrm{~mm}$ (5.9 in.) occur only once or twice each year on the average, and severe ice storms occur only once every 4 or 5 years (Denmark 1974).

The area experiences about 40 thunderstorms annually (NOAA 1980). Occasionally, these storms are accompanied by hail, damaging winds, or tornadoes. From 1957 to 1969 there were 371 tornadoes in the state, with more than $65 \%$ occurring during the spring months (NOAA 1970). The theoretical probability of a $67-\mathrm{m} / \mathrm{s}(150-\mathrm{mph})$ tornado strike at ANL is $3.0 \times 10^{-5}$ each year, a recurrence interval of one tornado every 33,000 years (Coats 1984). The ANL site has been struck by milder tornadoes, however, with minor damage to power lines, roofs, and trees.

\subsubsection{Air Quality}

National and state ambient air quality standards are listed in Table 3.2.1. Ambient air quality in the general vicinity of ANL is monitored at several sites. The Environment Safety and Health Department. (ESHD) of 


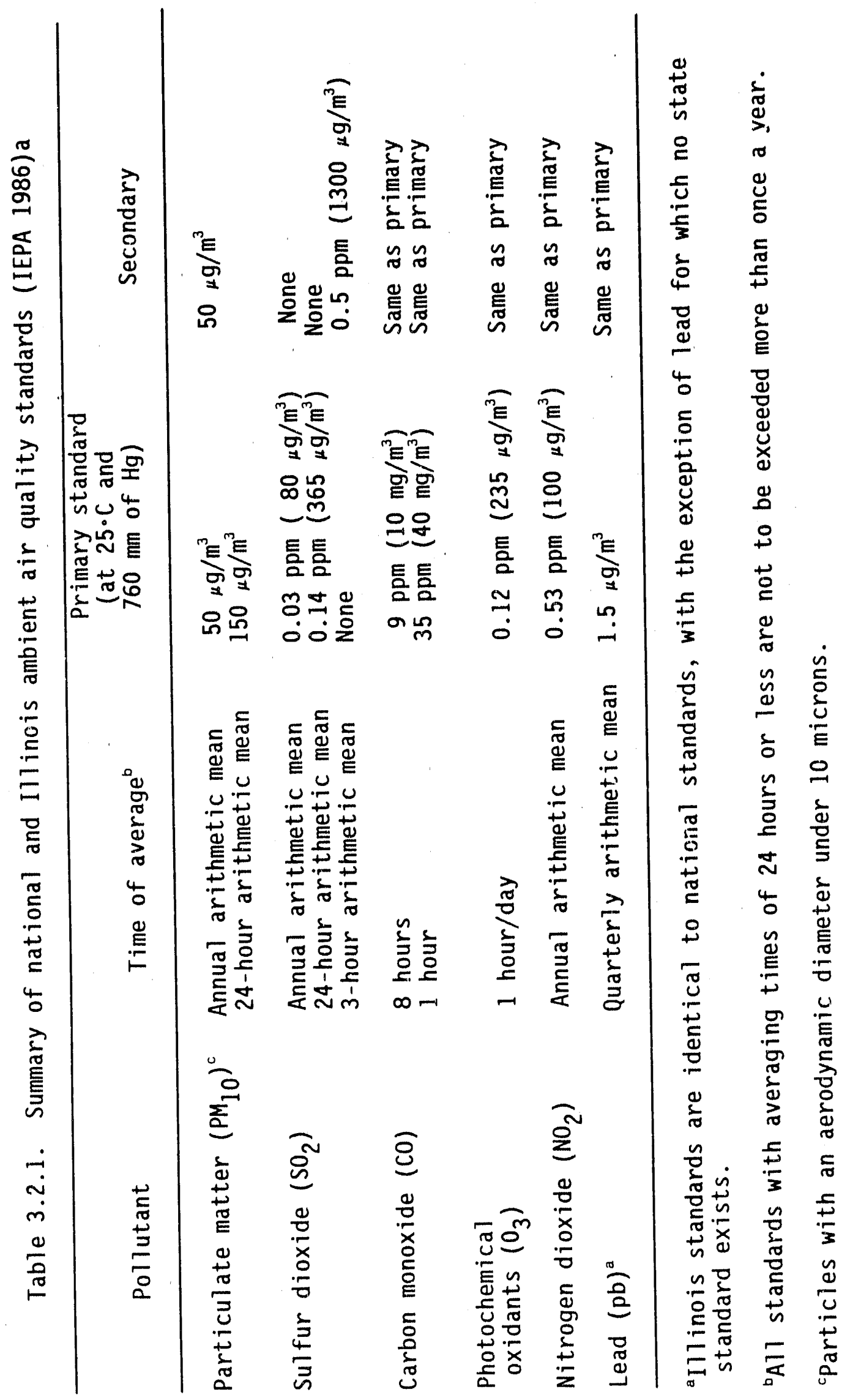


ANL monitors pollutants at five locations on the property, and the 111 inois Environmental Protection Agency (IEPA) and Commonwealth Edison Company collect data from a number of sites around ANL. Ambient air quality monitoring station locations are shown in Fig. 3.2.1.

Total suspended particulates (TSP) data provide a baseline for the evaluation of environmental consequences of APS construction activities. Evidence has indicated that the TSP level near ANL is the result of fugitive emissions (Golchert, Duffy, and Sedlet 1980). Table 3.2.2 lists TSP data from monitoring sites operated by ANL, regulatory agencies, and Commonwealth Edison Company. Monitors within a $16-\mathrm{km}(10-\mathrm{mile})$ radius were selected to represent the local air quality.

Aside from ANL's monitoring sites in Fig. 3.2.1 (8F, 12F, 12M, 14N, 18J), Darien and Lemont have the closest monitors. The highest TSP concentrations registered up to 1980 at these off-site monitors were $74 \mu \mathrm{g} / \mathrm{m}^{3}$ for an annual geometric mean and $208 \mu \mathrm{g} / \mathrm{m}^{3}$ for the second highest $24-\mathrm{h}$ average; these values were barely in compliance with the primary air quality standards for TSP in effect prior to July 31, 1987. After this date, standards for particulate matter under $10 \mu \mathrm{m}$ in diameter $\left(\mathrm{PM}_{10}\right)$ replaced national and state standards for TSP. The new primary and secondary $\mathrm{PM}_{10}$ standards were set at $150 \mathrm{mg} / \mathrm{m}^{3}$ for $24-\mathrm{h}$ averages and $50 \mathrm{mg} / \mathrm{m}^{3}$ for annual averages (Table 3.2.1). $\mathrm{PM}_{10}$ concentrations would be lower than TSP concentrations. However, the compliance status of the ANL area with respect to the new $P M_{10}$ standards has not yet been evaluated.

On the basis of the monitoring results of Table 3.2.2, the IEPA had classified Downers Grove township (the location of ANL) as nonattainment for secundary TSP standards, and adjacent Lemont and DuPage townships as 


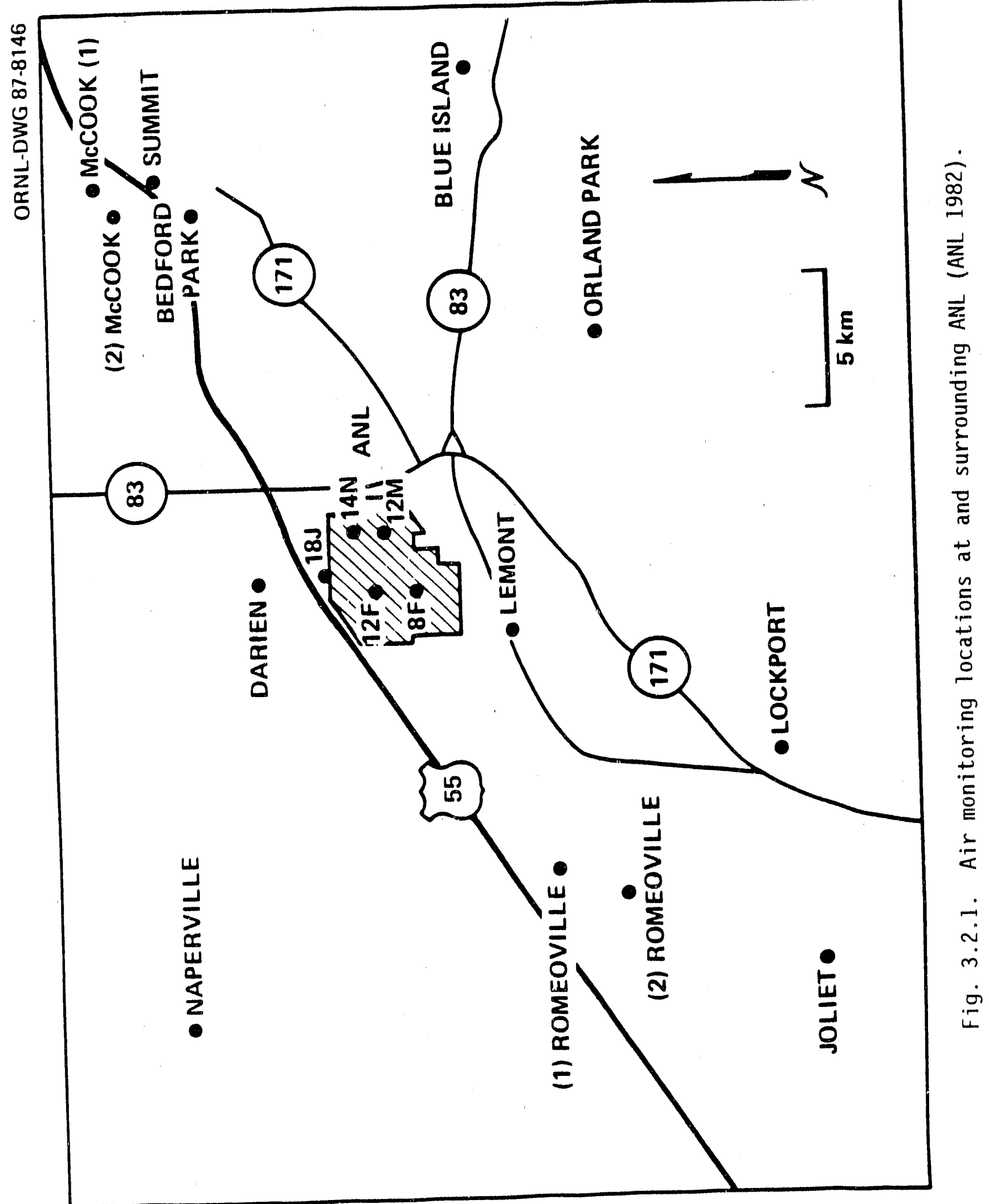


Table 3.2.2. Total suspended particles (TSP), in $\mu \mathrm{g} / \mathrm{m}^{3}$, from monitors located within an approximate $16-\mathrm{km}$ radius of ANL (ANL 1980)

\begin{tabular}{|c|c|c|c|c|c|c|c|c|c|}
\hline \multirow[b]{3}{*}{ Monitor } & \multirow{2}{*}{\multicolumn{3}{|c|}{ Geometric mean }} & \multicolumn{6}{|c|}{ 24-hour maximum } \\
\hline & & & & \multicolumn{2}{|c|}{1977} & \multicolumn{2}{|c|}{1978} & \multicolumn{2}{|c|}{1979} \\
\hline & 1977 & 1978 & 1979 & lst & 2nd & $1 \mathrm{st}$ & $2 n d$ & $1 s t$ & 2nd \\
\hline \multicolumn{10}{|c|}{ Cook County and Chicago } \\
\hline Bedford Parka & 64 & 61 & 69 & 133 & 126 & 136 & 125 & 235 & 154 \\
\hline Lemont ${ }^{b}$ & $-\mathrm{C}$ & 74 & $d$ & 134 & 126 & 489 & 195 & 211 & 208 \\
\hline $\operatorname{McCook}(1)^{a}$ & 110 & 87 & 74 & 209 & 187 & 212 & 145 & 148 & 147 \\
\hline $\operatorname{McCook}(2)^{a}$ & 101 & 81 & 70 & 219 & 217 & 171 & 151 & 140 & 131 \\
\hline Orland Park ${ }^{a}$ & 52 & 56 & 66 & 177 & 142 & 189 & 176 & 138 & 127 \\
\hline Summita & 78 & 80 & 84 & 196 & 186 & 225 & 209 & 194 & 193 \\
\hline \multicolumn{10}{|l|}{ Du Page County } \\
\hline Dariena & - & 69 & 69 & - & - & 195 & 188 & 143 & 135 \\
\hline Naperville $e^{a}$ & 58 & 53 & 60 & 165 & 135 & 135 & 131 & 122 & 119 \\
\hline $8 \mathrm{~F}^{\mathrm{e}}$ & 47 & 48 & 45 & - & - & - & - & - & - \\
\hline $12 \mathrm{Fe}^{\mathrm{e}}$ & 58 & 58 & 55 & - & - & - & - & - & - \\
\hline $12 M^{e}$ & 43 & 48 & 45 & - & - & - & - & 107 & 71 \\
\hline $14 N^{e}$ & - & 38 & 43 & - & - & - & - & - & - \\
\hline $18^{\mathrm{Je}}$ & 52 & 61 & - & - & - & - & - & - & - \\
\hline
\end{tabular}

Wi11 County

$\begin{array}{lccrrrrrrr}\text { Lockporta } & 63 & 53 & 70 & 164 & 157 & 203 & 123 & 214 & 180 \\ \text { Romeoville }(1)^{b} & 58 & - & 66 & 160 & 155 & 189 & 162 & 155 & 149 \\ \text { Romeoville }(2)^{b} & - & 54 & d & 107 & 90 & 202 & 140 & 156 & 151\end{array}$

Monitor operated by the 111 inois Environmental Protection Agency.

bMonitor operated by Commonwealth Edison Company.

CHyphen means no data.

dThe value given for 1978 is an average for 1 January 1978 to 31 December 1979.

eMonitor on the ANL site. 
nonattainment for primary TSP standards (EPA 1980; DOE 1982). However, a significant improvement in air quality was observed in the succeeding 5 years. As of February 1985, most of these townships had reached attainment status (IEPA 1985). The 1985 TSP concentrations (annual geometric mean) for Lemont, Darien, and Naperville were 67,41 , and $52 \mu \mathrm{g} / \mathrm{m}^{3}$, respectively (IEPA 1986).

\subsection{DEMOGRAPHY AND SOCIOECONOMIC PROFILE}

The proposed APS site is at ANL, located in DuPage County, Illinois, $40 \mathrm{~km}$ (25 miles) west of Lake Michigan, about $35 \mathrm{~km}$ (22 miles) southwest of downtown Chicago, and within the Chicago Standard Metropolitan Statistical Area (SMSA). This area comprises six Illinois and two Indiana counties around the southwest corner of Lake Michigan.

DuPage County's growth rate has been the highest of any metropolitan Illinois county. The nearby areas of Will and Cook counties have generally developed at a considerably lower rate, except along the 111 inois Waterway where industrial development has taken place. With its on-site work force of approximately 3760 people, ANL is one of the largest employers in DuPage County.

The estimated population by annular sector and radius within $80 \mathrm{~km}$ (50 miles) of ANL is shown in Table 3.3.1. More than 3.5 million people live within $32 \mathrm{~km}$ (20 miles) of ANL. About 8 million people live within the $80-\mathrm{km}$ (50-mile) radius, which includes portions of Lake and Porter counties, Indiana; portions of Kankakee, Grundy, La Salle, DeKalb, McHenry, and Lake counties in Illinois; and all of DuPage, Will, Cook, Kendall, and Kane counties in 11 linois. 


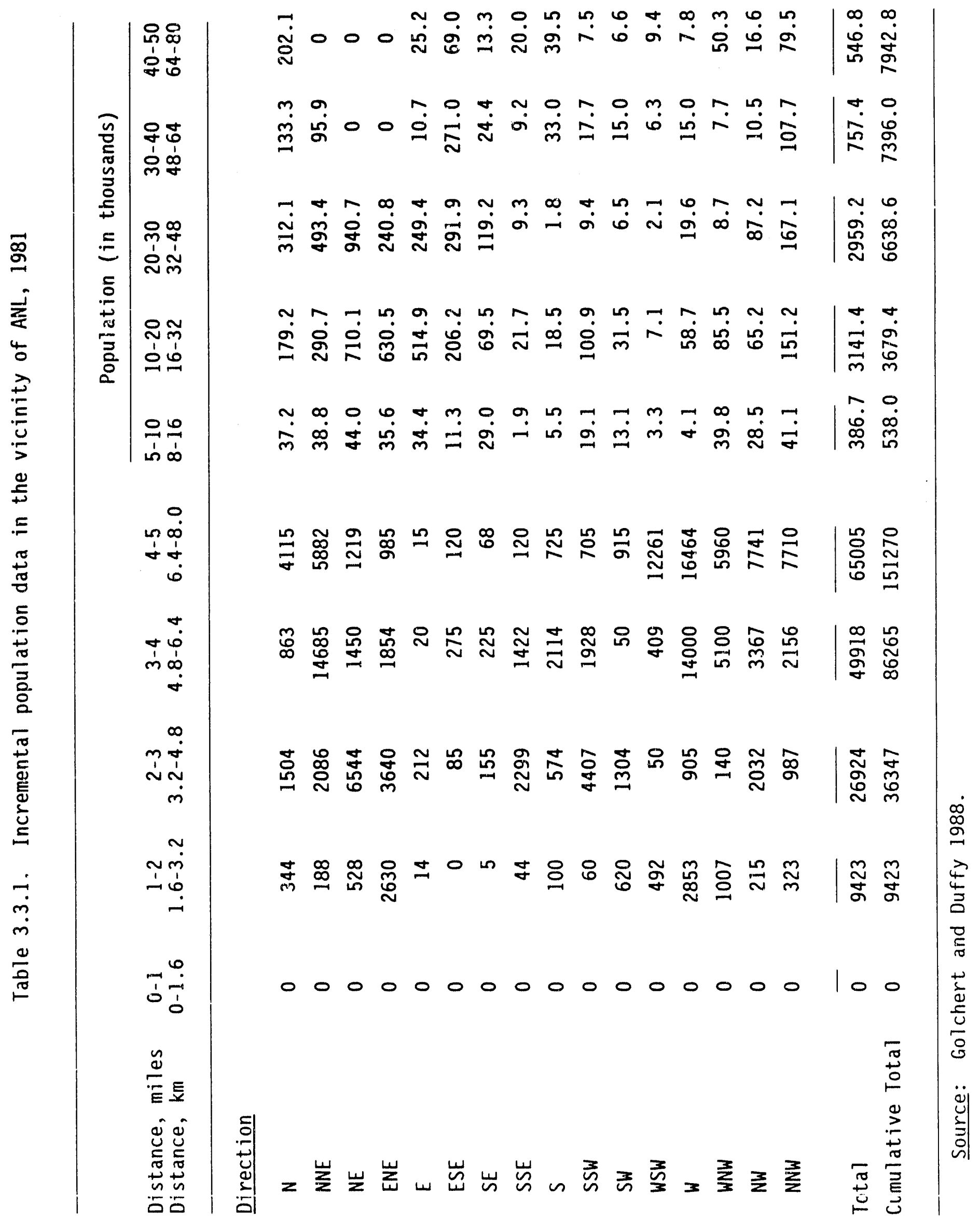


Beyond the forest preserve at ANL's perimeter, the population density increases rapidly, especially to the northeast. A high-density residential area (with several thousand residents) is $600 \mathrm{~m}(2000 \mathrm{ft}$ ) east of the perimeter.

The closest resident to APS is west southwest of the project site, approximately $1.4 \mathrm{~km}(0.9 \mathrm{mile})$ from the project centerline (Cho 1989a). The closest large populated subdivision is located northwest of the project site, west of the ANL West Gate entrance, on the west side of Lemont Road. The center of this development is approximately $2.1 \mathrm{~km}(1.3 \mathrm{miles})$ from the project centerline. Lemont (population 6080) to the southwest and Darien (population 16,390 ) to the north are the urban populations closest to the project site.

\subsection{LAND USE}

\subsubsection{Site and Vicinity}

Site. The APS site consists of undeveloped open fields and secondgrowth woodlands. The area was prairie and farmland before federal acquisition of the site in 1947. DuPage County land-use plans designate the area, including the site, as office, research, and development. This land-use commitment of the site to development precludes the land from being subject to the Farmland Protection Policy Act (7 USC 4201 et seq.).

An experiment involving five iysimeters is being conducted east of Kearney Road on the west edge of the APS site. The lysimeters are buried tanks and are being used to study radioactive leakage from solid ion-exchange resins. This program will not be impacted by the APS.

Vicinity. Land uses adjacent to the APS site consist of undeveloped ANL lands, laboratory facilities to northeast and east and the Waterfall Glen 
Forest Preserve to the west and south. A portion of the south ANL boundary is built around Saint Patrick's Cemetery (Fig. 1.3.2), about $220 \mathrm{~m}(720 \mathrm{ft}$ ) from the proposed storage ring. The forest preserve is managed by DuPage County for public recreation, nature preservation, and ecological demonstration. Much of the preserve was formerly ANL property that was deeded to DuPage County in the early 1970s. The area adjacent to the southwest boundary of ANL is used by visitors to the cemetery, occasional hikers, and for access to a field used for flying model airplanes. However, no quantitative data on use are available (Pentecost 1987).

The surrounding area is varied in land use, including commercial, residential, and heavy industrial. For example, along the 111 inois Waterway, about 8-11 km (5-7 miles) southwest of ANL, are large $0 i 1$ refineries and a large coal-fired electrical generating station. In addition, several large pipeline terminals for bulk storage of petroleum products and other chemicals are also present in the area.

\subsubsection{Archaeological and Historic Sites}

ANL is situated in an area known to have a long and complex cultural history. It is located in the Illinois and Michigan Canal National Heritage Corridor (Pub. L. 98-398, August 24, 1984).

\subsubsection{Prehistoric cultural resources}

All of the periods listed in the cultural chronology of Illinois (Curtis and Bebrich 1985), with the exception of the earliest period (Paleo-Indian), have been documented in the ANL area either by professional cultural resource investigation (e.g., Curtis and Berlin 1980) or by interviews of ANL staff with local collectors. A variety of site types, including mounds, quarries, 
lithic workshops, and habitation sites have been reported by amateurs within a $16-\mathrm{km}$ (10-mile) radius of ANL (Curtis and Bebrich 1985).

Three prehistoric sites, designated ANL-4, ANL-6, and ANL-23

(Fig. 3.4.1) and consisting of a surface scatter of lithic artifacts, were identified within the APS project area. Site archaeological efforts have revealed that ANL -4 and ANL-6 represent distinct concentrations of 1 ithic artifact debris. The sites correspond to different periods of prehistoric use, although they vary slightly in the type of artifactual materials recovered. Site cultural resource studies (EES 1988) confirmed and amplified earlier work which had suggested the presence of two sites, ANL-4 and ANL-6 (Curtis and Berlin 1980). This earlier work also suggested the presence of two other sites which, as a result of the present survey work (EES 1988), are known to be part of the ANL-23 site.

\subsubsection{Historic cultural resources}

In the mid-seventeenth century, the ANL area was occupied by the so-called Illinois Confederacy, composed of 12 related tribes, which included the Potawatomi, the Ottawa, and the Chippewa (Curtis, Rosenthal, and Stanish 1985). During the eighteenth century, European and American governments laid claims to twe land. Formal control of Indian lands was completed in 1816, when IITinois was purchased by the U.S. Government from the Potawatomi and their affiliates (Curtis, Rosenthal, and Stanish 1985). By 1834, early settlers had formed the community of Cass on what later became the ANL Reservation and now is Waterfall Glen Forest Preserve. The Cass post office, second oldest in DuPage County, was in operation from 1836 to 1885. During the early part of this period, construction of the Illinois and Michigan Canal took place. 


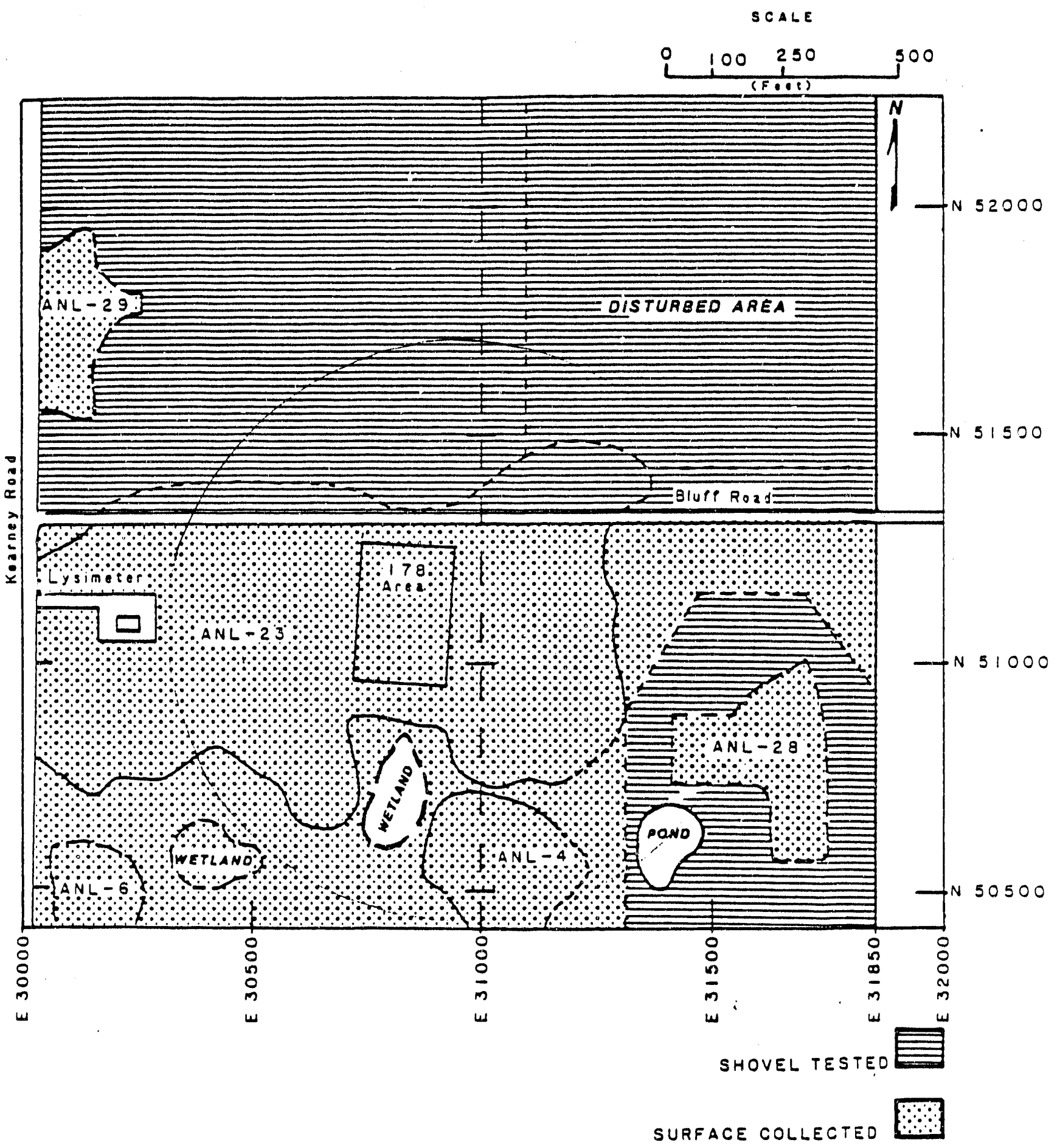

Fig. 3.4.1. Prehistoric and historic resources in the APS site, and survey methods used. 
Two historic sites, designated ANL-28 and ANL-29, have been identified (EES 1988) within the APS project area (Fig. 3.4.1). Located near the Illinois and Michigan Canal Corridor, ANL-28 and ANL-29 may be helpful in revealing some information about the period of canal construction and use. These farmstead sites were constructed beginning in the 1840s. They appear to have been continually occupied for over 100 years before their purchase by the government beginning in 1946. Subsequently, the building structures were either removed or demolished as the ANL site was developed.

Archaeological work (EES 1988) recovered over 1000 historic artifacts from these two sites. Materials consisted of mainly glass and ceramic artifacts, reflecting a variety of container types. Most of the artifacts found at ANL-28 were recovered as surface finds. Because the dense undergrowth was a site constraint at ANL-29, shovel testing proved to be the most efficient method for recovering artifacts.

In addition to artifactual remains, partially excavated evidence of structural features, including cement and cobble foundations, rock alignments and scatters, and well retaining walls, were found at both ANL-28 and ANL-29. Evaluation confirms that both sites functioned as farmsteads (EES 1988).

\subsection{GEOLOGY}

\subsubsection{Stratigraphy}

According to Soil and Material Consultants, Inc. (1986), the APS site is underlain by $34-37 \mathrm{~m}(113-123 \mathrm{ft}$ ) of glacial till (Wisconsin stage of the Pleistocene series). Lineback (1979) mapped this unit as the Wadsworth Till Member of the Wedron Formation and described it as a clayey to silty-clayey till with few pebbles and cobbles. Sasman et al. (1981) observed, however, that the base of this unit is locally rich in gravel. Gravel deposits are 
probably confined to valleys carved in the bedrock surface which now 1 ies buried beneath the Pleistocene sediments (alluvium and glacial till). Lithologic logs of 12 exploratory holes are consistent with Lineback's description. The till is overlain by less than $0.3-0.6 \mathrm{~m}(1-2 \mathrm{ft})$ of loess and modern soit.

Strata immediately underlying the till are identified as probably belonging to the Kankakee Formation of the Alexandrian Series, lowermost Silurian System. The subcropping weathered zone is up to $10 \mathrm{~m}(35 \mathrm{ft})$ thick. This zone shows significant evidence of solution weathering and fracturing, below which rock is generally unfractured and unaltered.

Silurian aquifers (including the Kankakee Formation) are separated from deeper Cambro-Ordovician aquifers by an aquitard, the Maquoketa Group (Ordovician). This group consists primarily of shale units. The top of the Maquoketa Group lies $75 \mathrm{~m}(246 \mathrm{ft})$ beneath the surface, and it is about $45 \mathrm{~m}$ $(148 \mathrm{ft}$ ) thick in the vicinity of the APS site (Sect. 3.7 ) according to maps published in suter et al. (1959).

\subsubsection{Soils}

According to USDA (1979), the site consists mainly of upland soils belonging to the Morley Series. These soils formed in silty clay loam glacial till. Locally, a thin layer of overlying silty material is present. In the proposed construction area, surfaces on these soils generally range from nearly flat to about $15 \%$ slope. These upland soils are deep, well drained, and moderately slow to slowly permeable. Small marshlands, ponds, and moderate erosional features are on the vicinity of the construction site.

Other soil series in and adjacent to the construction site are the Sawmill silty clay loam (along a tributary to Sawmill creek) and isolated 
areas of Blount silt loam, Ashkum silty clay loam, and Peotone silty clay loam. These soils differ from the Morley Series in that they are all poorly or very poorly drained and are in localized low-lying areas within the upland till plain. Table 3.5 .1 summarizes soil characteristics, and Fig. 3.5 .1 is a map of soit types at ANL.

\subsubsection{Seismicity}

No tectonic features within $100 \mathrm{~km}$ (62 miles) of ANL are known to be seismically active. The longest of these features is the Sandwich Fault. Smaller local features are the Des Plaines disturbance, a few faults in the Chicago area, and a fault of apparentily Cambrian age (DOE 1982).

Although a few minor earthquakes have occurred in northern Illinois, none has been positively associated with a particular tectonic feature. Most of the recent local seismic activity is believed to be caused by isostatic adjustments of the earth's crust in response to glacial loading and unloading, rather than by motion along crustal plate boundaries.

There are several areas of considerable seismic activity at moderate distances (hundreds of kilometers) from ANL (Hadley and Devine 1974). These areas include the New Madrid Fault zone (southwestern Missouri), the St. Louis area, the Wabash Valley Fault zone along the southern Illinois-Indiana border, and the Anna region of western Ohio. Although high-intensity earthquakes have occurred along the New Madrid Fault zone, their relationship to plate motions remains speculative at this time.

According to estimates by Algermissen et a1. (1982), ground motions induced by near and distant seismic sources in northern 111 inois are expected to be minimal. However, peak accelerations in the ANL area may exceed $10 \%$ of 


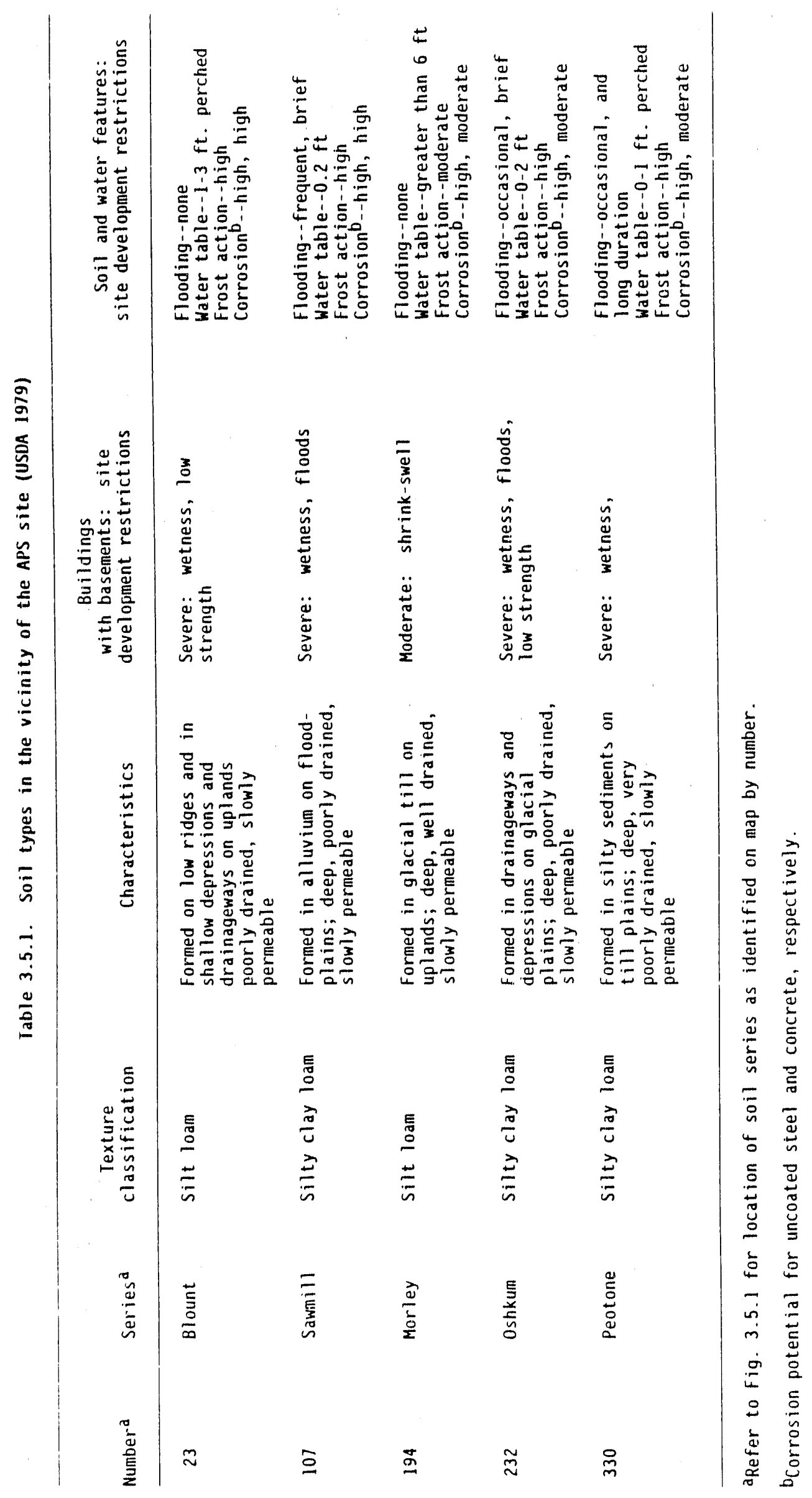




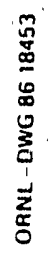

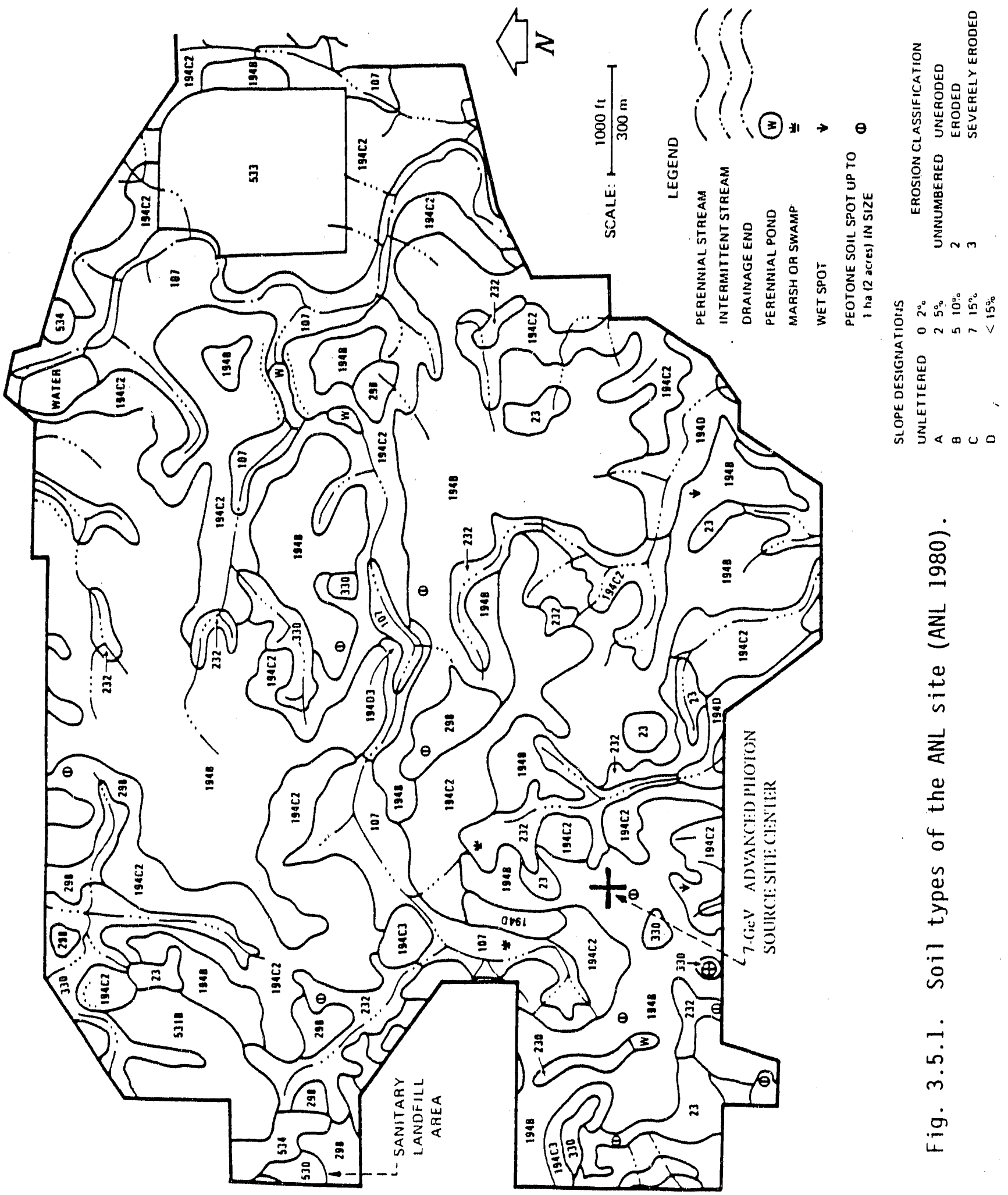


gravity (approximate threshold of major damage) once in about 600 years, with an error range of -250 to +450 years (Coats and Murray 1984).

\subsection{SURFACE WATER}

\subsubsection{Hydrology}

Four drainages that may intermittently have flowing water are located on the proposed APS site (Fig. 3.6.1). One originates just west of the site, crosses Kearney Road, and drains north to Freund Brook, which flows near the northwest corner of the site. Freund Brook flows to the east-northeast and enters Sawmill Creek, which flows south to the Des Plaines River. Another drainage in the northeast part of the site also drains northward to Freund Brook. Flow data for Freund Brook are not available. However, field observations of the stream size and channel configuration suggest that the discharge averages less than $0.08 \mathrm{~m}^{3} / \mathrm{s}\left(3 \mathrm{ft}^{3} / \mathrm{s}\right)$ and peaks at less than $0.6 \mathrm{~m}^{3} / \mathrm{s}$ $\left(21 \mathrm{ft}^{3} / \mathrm{s}\right.$ ) during the maximum flood stage (Golchert, Duffy, and Sedlet 1986; DOE 1982).

The remaining drainages originate in the south half of the site and drain southeast to a marsh along the Des Plaines River flood plain. The ANL site in general has a network of ditches and culverts that transport surface runoff without treatment toward the streams.

Sawmill Creek originates about $2.4 \mathrm{~km}$ ( 1.5 miles) north of ANL and flows southward through the eastern part of the ANL site. The ANL treated sewage discharge (50\% sanitary wastewater and 50\% laboratory wastewater) enters the creek about $1 \mathrm{~km}(0.6 \mathrm{mile})$ south of the ANL property boundary and about $305 \mathrm{~m}$ (1000 ft) upstream from the Des Plaines River. During rainstorms, much flow is contributed by surface runoff from built-up developments. ANL sewage 


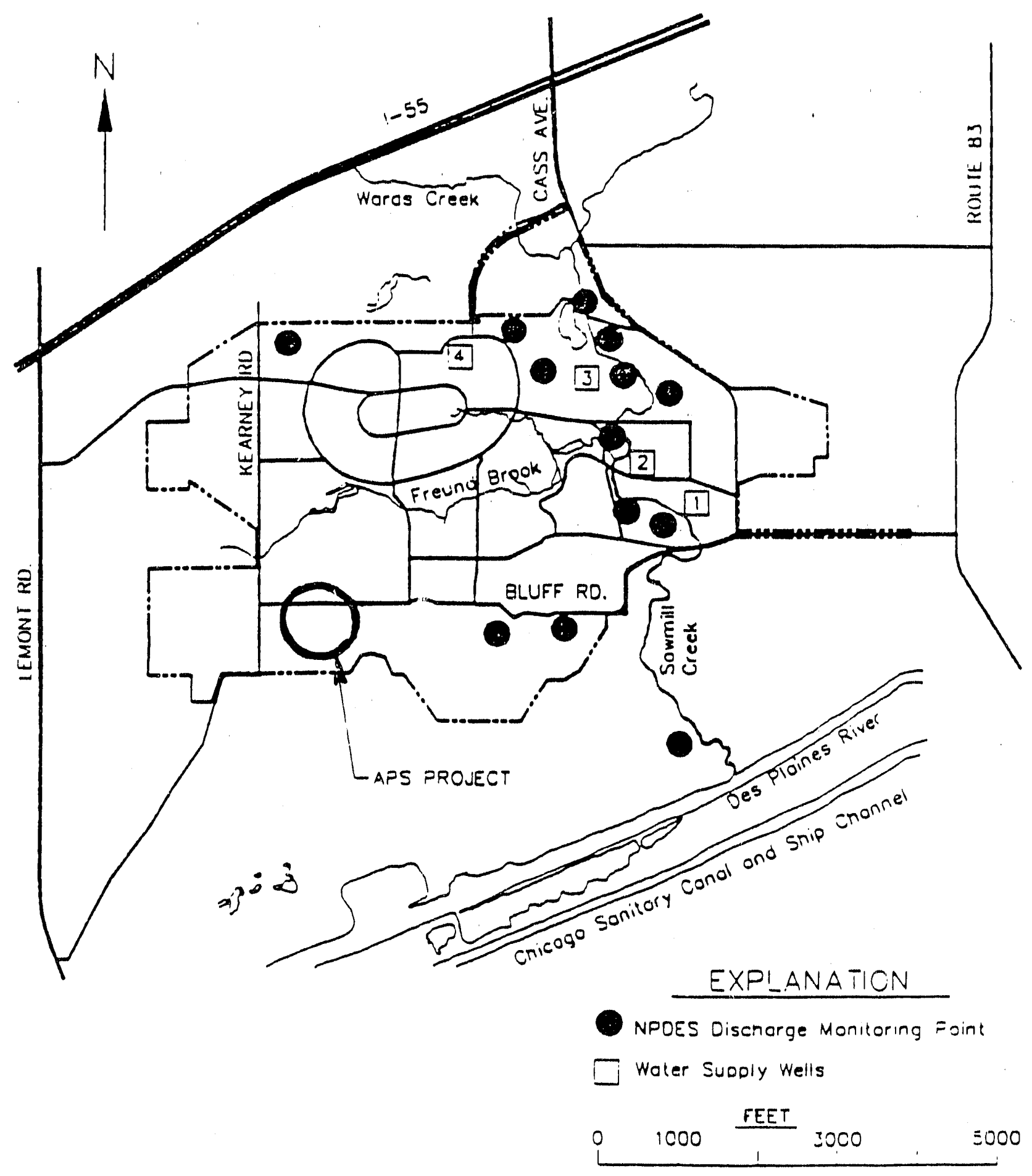

Fig. 3.6.1. Locations of NPDES discharge monitoring points and water supply wells at ANL. 
discharges averaged $0.044 \mathrm{~m}^{3} / \mathrm{s}\left(1.57 \mathrm{ft}^{3} / \mathrm{s}\right)$ in 1987 , while Sawmi11 Creek's flow above the discharge point averaged about $0.19 \mathrm{~m}^{3} / \mathrm{s}\left(6.6 \mathrm{ft}^{3} / \mathrm{s}\right)$. Before its closure on October 27, 1986, the Marion Brook (DuPage County) sewage treatment plant, located a few kilometers north of ANL, contributed about $0.14 \mathrm{~m}^{3} / \mathrm{s}\left(5 \mathrm{ft}^{3} / \mathrm{s}\right)$ to the flow in Sawmill Creek. Flow in the Des Plaines River ranges from 11 to $340 \mathrm{~m}^{3} / \mathrm{s}$ (400 to $\left.12,000 \mathrm{ft}^{3} / \mathrm{s}\right)$.

\subsubsection{Quality}

Sawmill Creek's flow through ANL decreased in 1986, when a trunkline sewer was placed into operation for sanitary treated wastewater which previously had been discharged to Sawmill creek. The stream had been classified as water-quality limited with respect to the dissolved oxygen content (DOE 1982). Data obtained in 1987 are listed in Table 3.6.1. The smaller streams on the ANL site drain old fields, woodlands, lawns, and parking lots. Concentrations of chemical constituents found in Sawmill Creek, $15 \mathrm{~m}(50 \mathrm{ft})$ upstream and $60 \mathrm{~m}(200 \mathrm{ft})$ dowristream from the wastewater outfal1, are listed in Table 3.6.2.

ANL effluents at 13 discharge points (Fig. 3.6.1) are regulated by a National Pollutant Discharge Elimination System (NPDES) permit. Total suspended solids (TSS) occasionaily have exceeded the permit levels at five of these locations, primarily when heavy rainfall occurred (Golchert and Duffy 1988). An average of $21 \%$ of the weekly or monthly TSS samples exceeded the permitted level by factors of 1.1 to 3.8 .

\subsubsection{Use}

Water from the Chicago Sanitary and Ship Canal is used by ANL for process cooling, by local industries for various purposes in addition to 


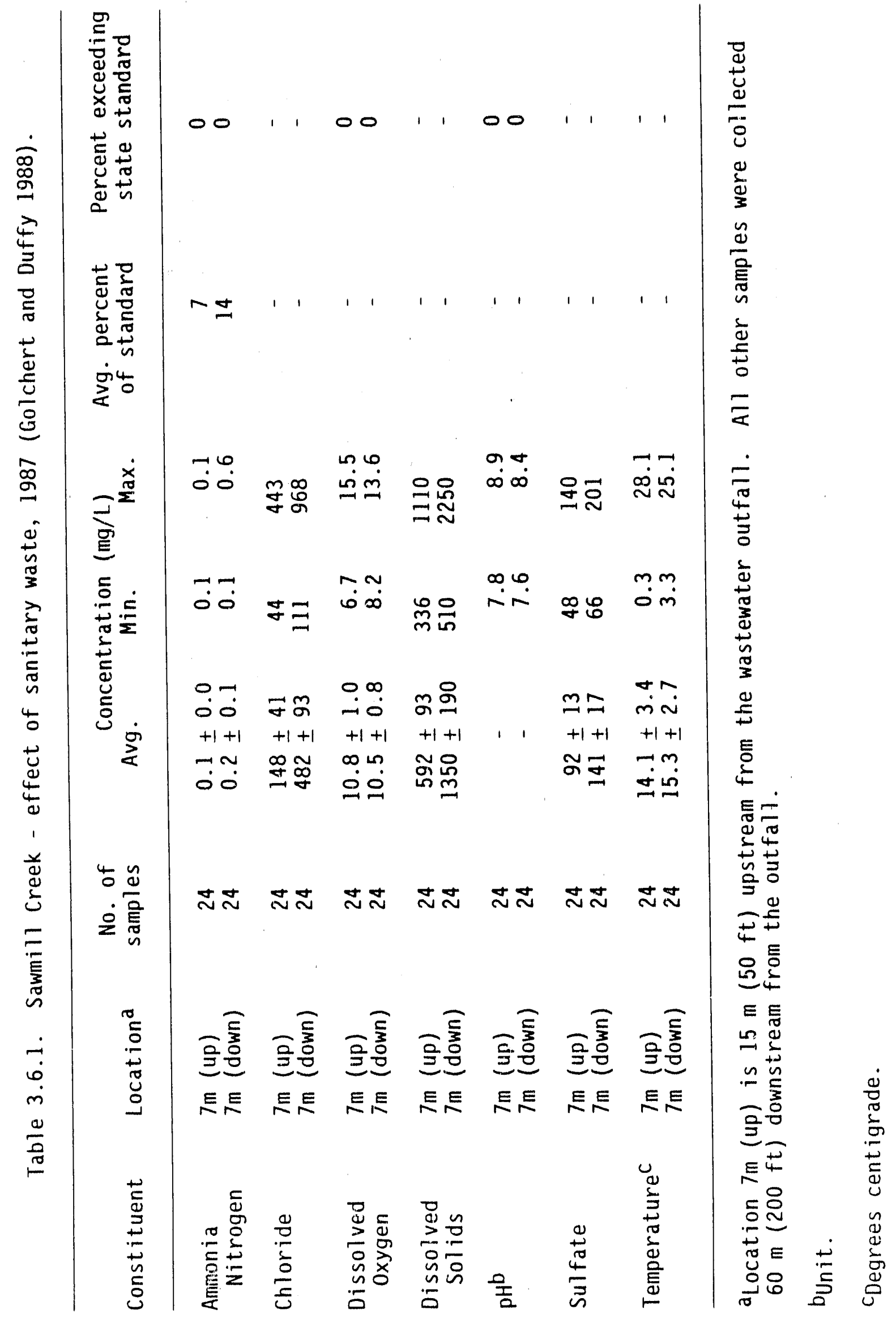




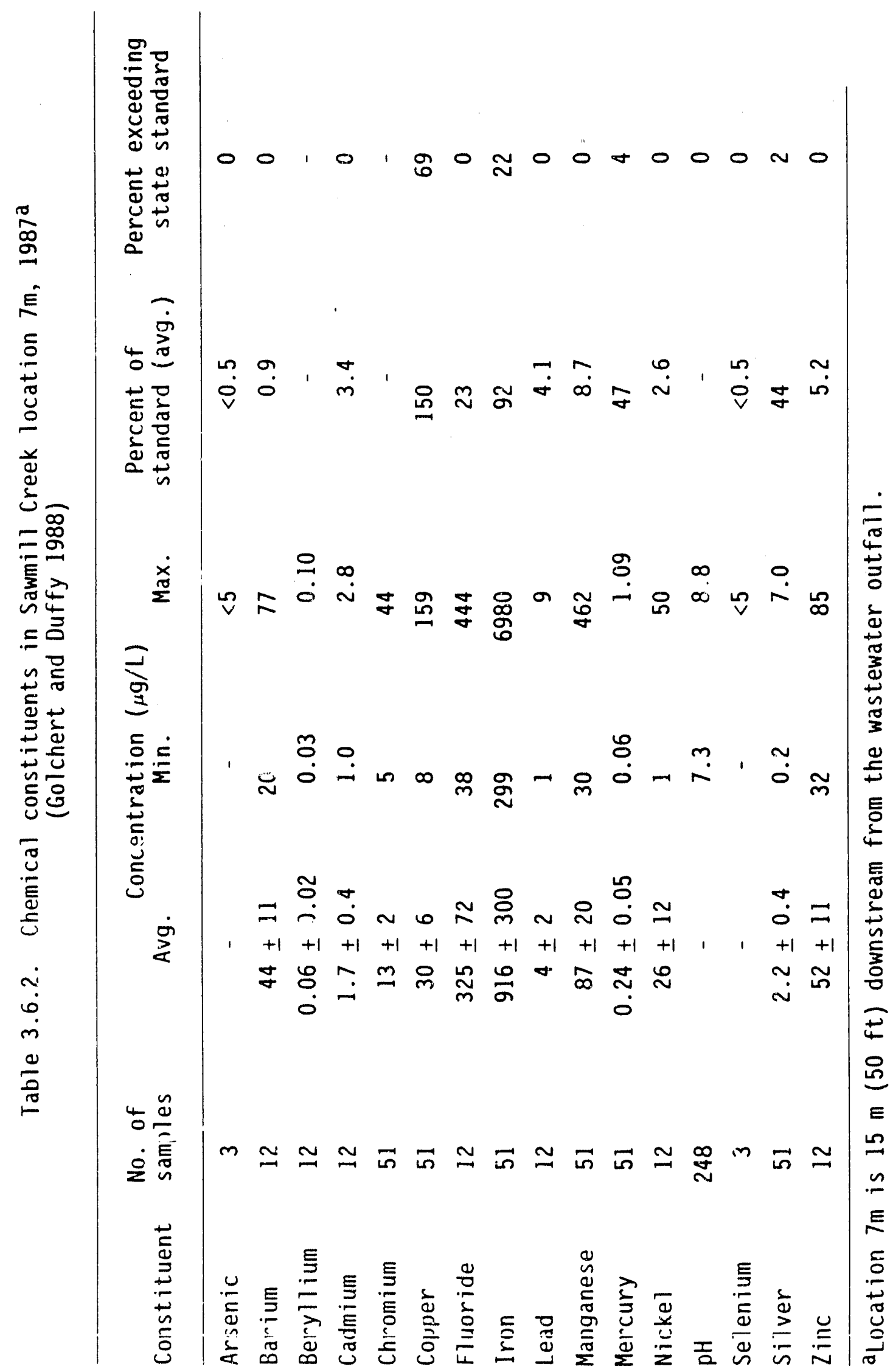


process cooling, and by the state prison near Joliet for irrigation. ANL usage is about $380 \mathrm{~m}^{3} / \mathrm{d}(0.1 \mathrm{Mgd})$, some of which is returned to the Canal via Sawmill Creek and the Des Plaines River. The Canal, which receives Chicago Metropolitan Sanitary District effluent water, is used for industrial transportation and some recreational boating. The nearest downstream use of the canal or river water for drinking is reported to be at Alton, on the Mississippi River, over 644 river $\mathrm{km}$ (400 river miles) from ANL (Golchert and Duffy 1988).

Sawmill Creek and the Des Plaines River above Joliet, about $21 \mathrm{~km}$ (13 miles) southwest (downstream) from ANL, exhibit very little recreation or industrial use. A few people fish in these waters downstream from ANL, and some duck hunting takes place on the Des Plaines River. Areas adjoining the creek and river, however, receive greater use. The Des Plaines River is a major focus for forest preserves and recreation activity in DuPage, Cook, and Lake counties. Sawmill Creek flows through Waterfall Glen Forest Preserve, a major recreational area and the largest forest preserve in DuPage County.

\subsection{GROUNDWATER}

Two principal aquifers have been used as water supplies in the ANL area (DOE 1980). The shallow aquifer, about 35 to $75 \mathrm{~m}$ (115 to $246 \mathrm{ft}$ ) deep, is the Silurian age Niagara-Alexandrian Dolomite (locally in hydraulic connection with Pleistocene alluvium in bedrock valleys). The deep aquifer is the Cambrian age Galesville sandstone (in hydraulic connection with the Franconia and St. Peter sandstones), which lies between 240 and $450 \mathrm{~m}$ (790 and $1500 \mathrm{ft}$ ) beneath the surface. These aquifers are separated by the $45-\mathrm{m}(148-\mathrm{ft})$-thick Maquoketa Group aquitard, about $75 \mathrm{~m}$ (246 ft) below the surface (Suter et al. 1959). 


\section{7 .1 Use}

According to Sasman et al. (1981) public and industrial water use of the combined Niagara-Alexandrian dolomite and Pleistocene alluvium doubled in the interval between 1966 and 1978; yields of shallow wells have drastically declined as a result of excessive pumping (Sasman 1974).

During the period from October 1980 through December 1985, pumpage from deep wells in the Chicago region decreased from 666,000 to $600,000 \mathrm{~m}^{3} / \mathrm{d}$ (175.9 to $157.7 \mathrm{Mgd}$ ), a decrease of $10.3 \%$. Changes in pumpage primarily refiect the transition from use of deep wells to water from Lake Michigan for public and industrial supplies, decreasing use of deep wells by self-supplied industries, and use of Fox River water to supplement the public water supply at Elgin in northeastern Kane County.

The four wells now in use at ANL (see Fig. 3.6.1) have yields of 1300 to $1900 \mathrm{~L} / \mathrm{min}$ (350 to $500 \mathrm{gal} / \mathrm{min}$ ) from the Niagara-Alexandrian aquifer, and they range in depth from 87 to $104 \mathrm{~m}(284$ to $341 \mathrm{ft})$. The water level in these wells dropped about $3 \mathrm{in}(10 \mathrm{ft}$ ) between 1960 and 1978 (Sasman et al. 1981).

\subsubsection{Quality}

According to Sasman et al. (1981), concentrations of total dissolved solids (TDS), hardness (as $\mathrm{CaCO}_{3}$ ), sulfate, chloride, sodium, and total iron in groundwater from DuPage and adjacent counties are high. For example, the median TDS in groundwater from DuPage County is $625 \mathrm{mg} / \mathrm{L}$ in comparison with EPA's secondary (suggested) standard of $500 \mathrm{mg} / \mathrm{L}$ for public drinking water. Table 3.7.1 list.s concentrations of selected inorganic and radioactive constituents in water for 1948 and 1987 for the shallow ANL domestic water supply wells shown in Fig. 3.6.1. These data are consistent with those of Sasman et al. (1981). The table shows an increase of $40 \%$ in the concentration 
of sulfate but indicates that only one parameter (turbidity) exceeds National Interim Primary Drinking Water Standards (NIPDWS). After treatment, turbidity is reduced by an order of magnitude. All volatile organics were below detection limits in 1987 for the four ANL domestic water supply wells (Golchert and Duffy 1988). All but one [bis(2-ethylhexy1)-phthalate] of the semivolatile organics were below detection limits. Samples were also analyzed for pesticides, herbicides, and PCBs, and none were found above detection limits.

\subsection{ECOLOGY}

\subsubsection{Terrestrial Biota}

ANL lies within the Prairie Peninsula of the Oak-Hickory Forest Region (Braun 1950). The Prairie Peninsula is a mosaic of oak forest, oak openings, and tall-grass prairie occurring in glaciated parts of 117 inois, northwest Indiana, southern Wisconsin, and parts of other states. Much of the natural vegetation of this area has been modified by clearing and tillage. Forests in the ANL region, which are predominantly oak-hickory forests, are somewhat limited to slopes of shallow, 111 -defined ravines or of low morainal ridges. Gently rolling to flat intervening areas between ridges and ravines, prior to their use for agriculture, were predominantly occupied by prairie. The predominant successional trend on these areas, in the absence of cultivation, is toward oak-hickory forest. Forests dominated by sugar maple, red oak, and basswood may occupy more pronounced slopes. Poorly drained areas, streamside communities, and floodplains may support forests dominated by silver maple, elm, and cottonwood (Braun 1950).

The APS site itself consists primarily of open fields (about $60 \%$ of 
Table 3.7.1. Inorganic and radioactive constituents in domestic water, 1987, for ANL Wells 1-4 compared to NIPDWS

(concentrations in $\mathrm{mg} / \mathrm{L}$ and $\mathrm{pCi} / \mathrm{L}$, respectively) ${ }^{a}$

\begin{tabular}{|c|c|c|c|c|c|c|}
\hline \multirow[b]{2}{*}{ Constituent } & \multicolumn{4}{|c|}{ Well Number } & \multirow{2}{*}{$\begin{array}{l}\text { Treated } \\
\text { water }\end{array}$} & \multirow[b]{2}{*}{ NIPDWS } \\
\hline & 1 & 2 & 3 & 4 & & \\
\hline \multicolumn{7}{|l|}{ Inorganic $(\mathrm{mg} / \mathrm{L})$} \\
\hline $\begin{array}{l}\text { Aluminum } \\
\text { Antimony } \\
\text { Arsenic } \\
\text { Barium } \\
\text { Beryllium } \\
\text { Cadmium } \\
\text { Chromium } \\
\text { Copper } \\
\text { Lead } \\
\text { Manganese } \\
\text { Mercury } \\
\text { Molybdenum } \\
\text { Nickel } \\
\text { Selenium } \\
\text { Silver } \\
\text { Sodium } \\
\text { Thallium } \\
\text { Vanadium } \\
\text { Zinc }\end{array}$ & $\begin{array}{l}<0.06 \\
<0.5 \\
<0.004 \\
0.094 \\
<0.001 \\
<0.004 \\
<0.02 \\
0.083 \\
<0.01 \\
0.035 \\
<0.0002 \\
<0.5 \\
<0.02 \\
<0.002 \\
<0.03 \\
36.9(20)^{c} \\
<0.03 \\
<0.01 \\
<0.02\end{array}$ & $\begin{array}{l}<0.06 \\
<0.5 \\
<0.004 \\
0.081 \\
<0.001 \\
<0.004 \\
<0.02 \\
<0.02 \\
<0.01 \\
0.019 \\
<0.0002 \\
<0.5 \\
<0.02 \\
<0.002 \\
<0.03 \\
24.4(15) c \\
<0.03 \\
<0.01 \\
0.027\end{array}$ & $\begin{array}{l}<0.06 \\
<0.5 \\
<0.004 \\
0.052 \\
<0.001 \\
<0.004 \\
<0.02 \\
<0.022 \\
<0.01 \\
0.016 \\
<0.0002 \\
<0.5 \\
<0.02 \\
<0.002 \\
<0.03 \\
22.4 \\
<0.03 \\
<0.01 \\
0.016\end{array}$ & $\begin{array}{l}<0.06 \\
<0.5 \\
<0.004 \\
0.050 \\
<0.001 \\
<0.004 \\
<0.02 \\
<0.02 \\
<0.12 \\
0.014 \\
<0.0002 \\
<0.5 \\
<0.02 \\
<0.002 \\
<0.03 \\
21.1 \\
<0.3 \\
<0.01 \\
0.011\end{array}$ & $\begin{array}{l}<0.06 \\
<0.5 \\
<0.004 \\
0.050 \\
<0.001 \\
<0.004 \\
<0.02 \\
<0.02 \\
<0.004 \\
<0.01 \\
<0.0002 \\
<0.5 \\
<0.02 \\
<0.002 \\
<0.03 \\
21.7 \\
<0.03 \\
<0.01 \\
0.011\end{array}$ & $\begin{array}{l}0.05 \\
1.0 \\
0.01 \\
0.05 \\
0.05 \\
0.002\end{array}$ \\
\hline $\begin{array}{l}\text { Chlorides } \\
\text { Fluorides } \\
\text { Sulfates } \\
\text { Turbidity (NTU) }\end{array}$ & $\begin{array}{l}79(4)^{C} \\
0.24^{140}(99)^{C} \\
11.4^{c}\end{array}$ & $\begin{array}{c}55 \\
0.29^{(3)^{C}} \\
1300_{6.4}^{(92)^{C}}\end{array}$ & $\begin{array}{c}49 \\
0.30 \\
100 \\
7.2\end{array}$ & $\begin{array}{c}42 \\
0.33 \\
140 \\
7.1\end{array}$ & $\begin{array}{c}58 \\
0.3 \\
150 \\
1.9\end{array}$ & $\begin{array}{l}1.4-2.4 \\
1.0\end{array}$ \\
\hline \multicolumn{7}{|l|}{ Radioactive $(\mathrm{pCi} / \mathrm{L})$} \\
\hline $\begin{array}{l}\text { Gross alpha } \\
\text { Gross beta } \\
\text { Tritium } \\
\text { Strontium-90 } \\
\text { Radium- } 226 \\
\text { Uranium (natural) }\end{array}$ & $\begin{array}{r}3.5 \\
7.4 \\
2.17 \\
- \\
- \\
-\end{array}$ & $\begin{aligned} & 5.0 \\
& 8.3 \\
& 141 \\
&<0.25 \\
& 0.94 \\
& 0.32\end{aligned}$ & $\begin{array}{r}3.4 \\
7.4 \\
122 \\
<0.25 \\
0.64 \\
0.47\end{array}$ & $\begin{array}{l}2.8 \\
6.5 \\
110 \\
<0.25 \\
0.72 \\
0.25\end{array}$ & $\begin{aligned} & 0.5 \\
& 3.5 \\
&<100 \\
&<0.25 \\
& 0.15 \\
& 0.31\end{aligned}$ & $\begin{array}{l}15.0 \\
50 \\
2 \times 10^{4} \\
8.0 \\
5.0\end{array}$ \\
\hline
\end{tabular}

a Golchert and Duffy 1988.

bFrom 40 CFR Pt. 265, Appendix III.

CData for 1948 from Knowles et al. (1963) 
site); lowland woods in early succession (approximately $20 \%$ of site); mature upland forest (approximately 10\% of site); and developed or disturbed land (about $10 \%$ of site). The lowland woods, which are located along drainages and in several poorly drained depressions, have few mature trees and are dominated by box elder, white ash, and silver maple. The upland forest, in the northeast portion of the site, is dominated by white, bur, and black oaks and shagbark hickory. It represents the largest forested area on the site. other tree species on the site are eastern cottonwood, black willow, basswood, American elm, slippery elm, black cherry, and red mulberry. The vegetation on the open fields was cleared to bare ground in the fall of 1986 for an archaeological survey (see Sect. 4.4 and Curtis et al. 1987). These fields had bluegrass, yarrow, Queen-Anne's lace, goldenrod, asters, bindweed, and cress.

Terrestrial vertebrates that are commonly observed or likely to occur on the site include about 5 species of amphibians, 7 species of reptiles, about 40 species of summer resident birds, and 25 species of mammals. More than a hundred other bird species occur in the area during migration or winter but do not nest on the site or in the surrounding region. An unusual species on the ANL site is the fallow deer, a European species that was introduced to the area by a private landowner prior to government acquisition of the property in 1947 and which subsequently increased to about 400 individuals. In November 1988, about 200 of the deer were removed for population control. Native white-tailed deer also occur on the ANL reservation. Lists of species that occur at ANL and that could be expected to occur on the proposed APS site are provided in DOE (1982). Invertebrate species, as well as plants and other animals, observed on the ANL site were reported by Messenger, Suter, and Wagner (1969). 


\subsubsection{Floodplains and Wetlands}

The 100-year floodplain of Fruend Brook and several wetlands exist at or in the vicinity of the APS site. These are designated by letters $A$ through $F$ in Fig. 3.8.1 and are described below. The location, size and characteristics of these areas were determined based on several sources including flood insurance maps (FEMA 1982), U.S. Fish and Wildlife Service (FWS) National Wetl and Inventory maps, USGS and other topographical maps of the area, Northeastern Illinois Planning Commission aerial photograph (1985), and information collected during field surveys. The 100-year floodplain (Area F) is associated with the upper reaches of Freund Brook, a tributary to Sawmill Creek that traverses an area at the northwest edge of the APS site.

Area $A$, which is 0.16 ha $(0.4$ acre $)$, is in a wooded area at the southeastern portion of the APS site. According to the FWS classification system, the area is palustrine, unconsolidated bottom/emergent, saturated, and semipermanent. Water is present in the pond except during exceptionally dry summers such as occurred in 1988. Because of its perennial nature and relatively undisturbed state, this wetland provides habitat for a variety of wildlife species.

Area $B$, which is 0.28 ha $(0.7$ acre $)$, is palustrine, with emergent/scrub shrub, and is surrounded by a fringe of cottonwoods and willows. It is intermittently flooded during the fall, winter, and spring. During seasonally wet periods, it is frequented by a variety of wildlife species.

Area $C$ is a small depression [0.45 ha ( 1.1 acres)] surrounded by open field. It is occasionally flooded during periods of heavy rain, but it has saturated soil conditions for sufficient periods to support a number of facultative and obligate hydrophytic species. Field survey of this area 


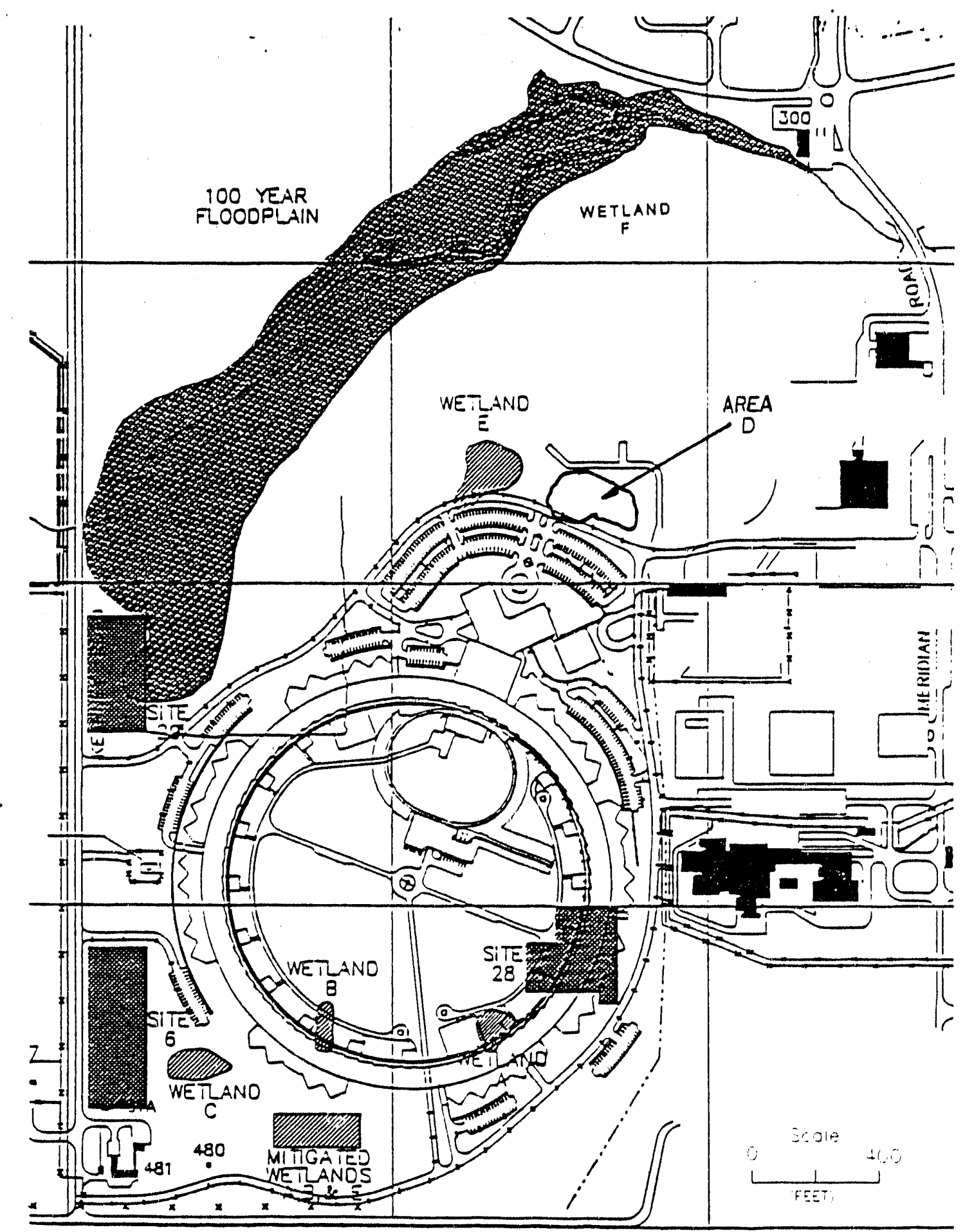

Fig. 3.8.1. Floodplains and wetlands on the APS site. 
identified the dominant species as leafybract beggar-ticks and the occurrence of the state-endangered hairy marsh yellow cress.

Area $D$ was a partially filled excavation with standing water $[0.40$ ha (approximately 1.0 acre)] and steep slopes. It had no emergent vegetation and nrovided little if any wildlife habitat. As an action separate from APS, DOE obtained authorization from the U.S. Army Corps of Engineers (COE) to fill the excavation with the original excavated material stockpiled immediately southwest of the excavation (COE 1988). The filling operation has been completed.

Area E, which is 0.28 ha $(0.7$ acre $)$, is described as a palustrine, emergent, saturated/semipermanent seasonal wetland. It is surrounded by a fringe of willows and box elders. Overflow from this area drains into a narrow (2-m wide) open water channel extending to Freund Brook.

Area $F$ is a wetland complex associated with the 100-year floodplain of upper Freund Brook. Near Outer Circle Road, to the extreme north of the proposed APS site, a small concrete weir restricts water flow and impounds approximately $400 \mathrm{~m}(1320 \mathrm{ft})$ of the stream. This impoundment is approximately one-fourth open water, with the remaining lowland dominated by cattails and standing dead trees. Upstream from this impoundment, most of the 100-year floodplain was flooded by beaver activity in the fall of 1986 . Patches of open water, a cattail marsh, and previously flooded stands of trees are located in this upstream area. This entire wetland complex is ecologically important because it is a permanent source of open water, relatively large in size [approximately 5.5 ha (13.6 acres)], generally undisturbed, and contains a variety of habitats. It supports a number of wildlife species and migrant waterfowl such as mallard, wood duck, green-back heron, and black-crowned night heron (the latter is listed as endangered by 
the state of Illinois).

A summary of wetland type, size, and functional importance of wetland features at or in the vicinity of the proposed APS site is presented in Table 3.8.1. All wetland areas are classified as palustrine, but they vary in being dominated by open water, trees, or emergent vegetation. They differ in functional importance largely based on size and species associated with them. All wetlands at the project site are estimated to have a low importance for providing water supply, flood control, timber, food, and recreation, generally because of their relatively small size. All but the wetland complex (Area F) are ranked low in importance for water quality and water recharge and discharge functions. The artificial and natural dams in Area $F$ provide catchment basins for sediment deposited within upper Freund Brook and serve to dampen fluctuations in water discharge rates. All but Area $D$ are ranked moderate to high in importance for habitat.

\subsubsection{Aquatic Biota}

Freund Brook crosses the extreme north corner of the site but is impounded by a beaver dam in this area (Sect. 3.8.1). The gradient of the stream is relatively steep, and riffle habitat predominates. The substrate is coarse rock and gravel on a firm mud base. Primary production in the stream is limited by shading, but diatoms and some filamentous algae are common. Aquatic macrophytes include common arrowhead, pondweed, duckweed, and bulrush. Invertebrate fauna consist primarily of dipteran larvae, crayfish, caddisfly larvae, and midge larvae. Few fish are present because of low summer flows and high temperatures. Other aquatic habitats on the ANL site include 
Table 3.8.1. Wetland type, size, and functional importance in the APS project area and vicinity.

\begin{tabular}{|c|c|c|c|c|c|c|}
\hline Wet 1 and ${ }^{a}$ & $A$ & $B$ & C & $D$ & $E$ & $F$ \\
\hline Wet 1 and Type & PUB/EM/FO & PEM/FO & PEM & PUBr & PEM & $\mathrm{PEM} / \mathrm{FO} / \mathrm{UBb}$ \\
\hline $\begin{array}{c}\text { Size in hectares } \\
\text { (acres) }\end{array}$ & $\begin{array}{l}0.16 \\
(0.4)\end{array}$ & $\begin{array}{l}0.28 \\
(0.7)\end{array}$ & $\begin{array}{r}0.45 \\
(1.1)\end{array}$ & $\begin{array}{l}0.40 \\
(1.0)\end{array}$ & $\begin{array}{l}0.28 \\
(0.7)\end{array}$ & $\begin{array}{c}5.5 \\
(13.6)\end{array}$ \\
\hline \multicolumn{7}{|l|}{ Importance: ${ }^{\mathrm{C}}$} \\
\hline Water supply & $L$ & $L$ & $L$ & $L$ & $L$ & $L$ \\
\hline Water quality & $L$ & L & $L$ & $L$ & $L$ & $M$ \\
\hline Recharge/discharge & $L$ & $L$ & $L$ & $L$ & $L$ & M \\
\hline Flood control & $L$ & $L$ & $L$ & $L$ & $\mathrm{~L}$ & $L$ \\
\hline Habitat & $M$ & $M$ & $H$ & $L$ & $M$ & $H$ \\
\hline Timber & $L$ & $L$ & $L$ & $L$ & $L$ & $L$ \\
\hline Food & $L$ & $L$ & $L$ & $L$ & $L$ & $L$ \\
\hline Recreation & $L$ & $L$ & $L$ & $L$ & $L$ & $L$ \\
\hline
\end{tabular}

Wetlands correspond to those shown in Fig. 3.8.1.

'Wetland types were based on the classification scheme of Cowardin et al., 1979. $P=$ palustrine, $E M=$ emergent vegetation present, $F 0=$ trees present, $U B=$ unconsolidated bottom (open water), $b=$ modified by beaver, 5 = artificial.

'Importance ratings: $L=$ Low $M=$ Moderate, $H=$ High. Wetland functions are based on those identified in EO 11990. 
additional beaver ponds, artificial ponds, ditches, and Sawmill creek (DOE 1982).

The biotic community of Sawmill Creek is relatively depauperate, reflecting the creek's high silt load, steep gradient, and historic release of sewage effluent from the Marion Brook sewage-treatment plant, which closed in the winter of 1986-87. The fauna consists primarily of blackflies, midges, isopods, flatworms, segmented worms, and creek chubs. A few other species of minnows, sunfishes, and catfish are also present. clean water invertebrates, such as mayflies and stoneflies, are rare or absent. The fish species that have been recorded in ANL aquatic habitats are the following: black bullhead, bluegill, creek chub, golden shiner, goldfish, green sunfish, largemouth bass, stoneroller, and orange-spotted sunfish (DOE 1982; Messenger, Suter, and Wagner 1969). The Des Plaines River system, including ANL streams, has been rated as "poor" in terms of the fish species present, a result of domestic and industrial pollution and stream modification (Smith 1971).

\subsubsection{Threatened and Endangered Species}

Although the geographic ranges of several federally listed animal species include the northern I17inois region (FWS 1986), no suitable habitat for these species is present on the proposed APS site, with the possible exception of the Indiana Bat (Myotis sodalis). An unconfirmed capture of an Indiana bat in nearby Waterfall Glen Forest Preserve indicates that the bat may occur in the ANL region. Consultation with the U.S. Fish and Wildlife Service (FWS) determined that suitable habitat for this species does not exist on the area that would be affected by APS construction (see Appendix C). The bald eagle, peregrine falcon, piping plover, interior least tern, and 
Kirtland's warbler could occur in the ANL area as extremely rare nonbreeders during migration or winter.

Numerous species 1 isted by the state of 111 inois have been recorded in DuPage County, including one bird species and 26 plant species (IDC 1981). The black-crowned night heron (Nycticorax nycticorax) and hairy marsh yellow cress (Rorippa islandica var. hispida) are both listed as endangered (IDC 1981) and have been documented on the ANL site. The hairy marsh yellow cress occurs in Area $C$, and the black-crowned night heron occurs in Area $F$ (Fig. 3.8.1). No other species on the state list are known to occur at ANL (Buhnerkempe 1988).

\subsection{EXISTING ENVIRONMENTAL MONITORING PROGRAMS}

\subsubsection{Radiological}

The basic occupational exposure limit for DOE contractors is 5 ren/year for whole-body exposure (DOE 1988b). However, it is DOE's and ANL's pulicy to keep radiation exposures as low as reasonably achievable (ALARA). The DOE, in keeping with the principles of ALARA, has set as a design objective for new facilities, a radiation exposure limit that is one-fifth of the $5 \mathrm{rem} /$ year whole-body exposure limit. In addition, DOE has proposed that the predicted exposure to individual members of the public should not exceed $25 \mathrm{mrem} /$ year (DOE 1984). These guidelines for on-site and off-site locations would be used for operation of the facility in order to keep exposures as low as reasonably achievable.

The ANL radiological monitoring program has been in operation since 1948, and monitoring results have been published in a series of annual reports. These data provide a baseline for measuring impacts of present and future projects. 
The radioactivity of the environment is routinely determined by monitoring ambient external penetrating radiation and radioactive nuclides in air, water, soil, and food. Sample collections and measurements are made at the ANL boundary and off-site for comparison purposes. Some on-site results are also reported when they are useful in interpreting perimeter and off-site results. Because radioactivity is usually spread by air and water, the sample collection program has concentrated on these media. In addition, soil, plants, foodstuffs, precipitation, and materials from the beds, lakes, and streams are also routinely collected and analyzed (Golchert, Duffy, and Sedlet 1986). The measured concentrations or radiation doses are compared with DOE radiation protection standards for uncontrolled areas (DOE 1988a).

The present DOE Radiation Protection Standard for uncontrolled areas (i.e., for members of the public) is 100 mrem/year maximum for whole body (Vaughan 1985). This standard is being revised, and it is anticipated that the new standard would limit exposure to members of the public from DOE activities such that no individual shall receive in one year an effective dose equivalent greater than 100 mrem or a tissue dose equivalent greater than 5 rem (DOE 1988a). Any actual or potential individual dose equivalent exceeding $25 \mathrm{mrem} / \mathrm{year}$ must be reported to DOE. In addition, DOE facilities with airborne releases are subject to 40 CFR Pt. 61, Subpart H (EPA 1985), which requires the use of the EPA-AIRDOS/RADRISK code to demonstrate compliance with this regulation. The dose limits for the air pathway are 25 mrem/year to the whole body and $75 \mathrm{mrem} /$ year to any organ.

Measurements of external penetrating radiation are routinely performed at ANL with calcium fluoride and lithium fluoride thermoluminescent dosimeter (TLD) chips. Dosimeters are exposed at a number of locations at the site boundary and on-site. Readings are also taken, for comparison purposes, at 
five off-site locations unaffected by ANL operations (Golchert and Duffy 1988).

Table 3.9.1 summarizes results for 1987 for these off-site locations. Measurements were made for the four successive exposure periods shown, and the results were calculated in terms of annual dose. The average $90 \mathrm{mrem} / \mathrm{year}$, excluding radon, may be considered the normal background for the ANL area.

External penetrating radiation measurements at 14 ANL boundary and onsite locations (including the proposed APS site) show normal background near the proposed APS site and a dose range of from 78 to 112 mrem for most other locations. Four monitoring locations have high readings (Golchert and Duffy 1988). The location closest to the proposed APS site is near the old CP-5 reactor site, $200 \mathrm{~m}(65.0 \mathrm{ft})$ from the proposed APS site perimeter, with $608 \mathrm{mrem} /$ year. The highest reading $(7000 \mathrm{mrem} / \mathrm{year})$ is found at the ANL Radioactive Waste Storage Facility, which is $830 \mathrm{~m}(2720 \mathrm{ft}$ ) from the proposed APS site perimeter. The calculated dose from these sources at the proposed APS site is less than $0.01 \mathrm{mrem} /$ year.

The average background radiation level at ANL is near the national average, with a value of $28 \mathrm{mrem} /$ year for both cosmic and terrestrial external radiation, and $39 \mathrm{mrem} /$ year for internal (ingested and inhaled) radiation. An additional $200 \mathrm{mrem} / \mathrm{yrar}$ (the national average) come from radon and its shortlived daughters (NCRP 1987).

\subsubsection{Nonradiological}

Nonradiological air monitoring activities at ANL and surrounding areas are reviewed in connection with ANL air quality (Sect. 3.2.2). Emphasis is placed on total suspended particulates (TSP) data, because they provide a baseline for the evaluation of environmental consequences of the proposed APS 
Table 3.9.1. Environmental penetrating radiation at off-site locations, 1987 (Golchert and Duffy 1988)

\begin{tabular}{lccccc}
\hline & \multicolumn{5}{c}{ Dose rate (mrem/year) } \\
\cline { 2 - 6 } & \multicolumn{5}{c}{ Period of measurement } \\
\cline { 2 - 6 } Location & $1 / 5-4 / 9$ & $4 / 9-7 / 16$ & $7 / 16-10 / 15$ & $10 / 15-1 / 17$ & Average \\
\hline Lemont & 85 & 90 & 98 & 88 & $90 \pm 6$ \\
Lombard & 87 & 92 & 101 & 92 & $93 \pm 6$ \\
Oak Brook & 88 & 95 & 99 & 90 & $93 \pm 5$ \\
Oak Lawn & 78 & 82 & 84 & 80 & $81 \pm 3$ \\
Woodridge & 87 & 93 & 95 & 89 & $91 \pm 4$ \\
\cline { 2 - 6 } & $85 \pm 4$ & $90 \pm 5$ & $95 \pm 7$ & $88 \pm 5$ & $90 \pm 5$ \\
Average & & & & & \\
\end{tabular}

construction. Details of ANL air monitoring programs for $\mathrm{SO}_{2}$ and $\mathrm{NO}_{x}$ are provided in the ANL environmental assessment (DOE 1982).

Surface water quality is monitored at numerous sampling stations to determine compliance with state regulations and the National Pollutant Discharge Elimination System (NPDES) permit (Fig. 3.6.1). The major discharge of wastewater from ANL is by way of the Wastewater Treatment Plant, which would also receive liquid effluents from the proposed APS facility. Water samples from ANL discharge are withdrawn continuously and analyzed daily for ammonia, nitrogen, total dissolved solids, $\mathrm{pH}$, and the 15 elements for which state standards have been established. 
Weekly and monthly surface water samples are collected at 13 sampling stations for the NPDES permit (Golchert and Duffy 1988). Although ten parameters are measured, an average of four is measured at each station. Parameters monitored include flow; total suspended solids (TSS); total dissolved solids (TDS); chlorides; pH; temperature; biological oxygen demand (BOD); chemical oxygen demand (COD); and fats, oils, and grease. The locations of sampling stations include the ANL Wastewater Treatment Plant, Freund Brook near its confluence with Sawmill creek, and Sawmill creek both upstream and downstream from the discharge of the Wastewater Treatment Plant. In April 1987, ANL reviewed its laboratory-wide water monitoring program in connection with the proposed APS project; it is not considered likely that ANL permit modifications would be required for the proposed APS site (Pentecost 1987). 
CHAPTER 4

\section{ENVIRONMENTAL CONSEQUENCES OF THE PROPOSED ACTION}

\subsection{CONSTRUCTION IMPACTS}

\subsubsection{Land Use and Disturbance}

The proposed 28-ha (70-acre) site would be converted from grasslands, fields, and woodlands to a predominantly built-up area including the APS facility and landscaped grounds. Because this property is currently part of the ANL site and has been intended to eventually support energy research facilities, this land conversion is in accord with long-range ANL planning and would have no significant direct effect on land use (ANL 1986). Development of the Entire APS site would decrease the amount of undeveloped areas in the ANL property by approximately $15 \%$. No prime farmland subject to protection under the Farmland Protection Policy Act is present on the site (Sect. 3.4.1).

Because of the relatively small size of the additional work force needed (see Sect. 4.3) and the fact that the ANL region is already highly urbanized, any 1 and use effects from a small increase in the ANL work force would be insignificant. No construction would occur in the Waterfall Glen Forest Preserve (including Saint Patrick's Cemetery), which is adjacent to the site. The preserve would not be directly impacted by the proposed action other than by temporary, typical construction noise and insignificant changes in air quality due to the operation of construction equipment. Therefore, construction of APS should have no significant long-term effects on recreation, nature preservation, or other land uses of the preserve.

Excavation and earth moving during construction are discussed in detail in Sect. 2.1.4. Approximately $138,500 \mathrm{~m}^{3}(181,100$ cubic yards) of material 
would be excavated during APS construction. The ANL on-site landfill is considered sufficient to accommodate all excess material.

Construction could potentially increase erosion, sediment-laden surface runoff, and turbidity and sedimentation of local streams and rivers. An ANL policy for both the Laboratory and its contractors is to use standard soil conservation measures to minimize erosion and sedimentation (Reinsch 1986). The policy states that soil disturbance procedures must comply with EPA manuals, namely "Guidelines for Erosion and Sedimentation Control Planning and Implementation" (EPA-R2-72-015) and "Processes, Procedures, and Methods to Control Pollution Resulting from All Construction Activity" (EPA-430/9-73-007). This policy also addresses the disposal of water from construction sites to ensure that surface water quality would not be adversely affected. In compliance with the requirements of the COE nationwide permit, reestablished and newly created wetlands would be protected. An erosion and sedimentation control plan is described in ANL (1987a). Various planned control measures include limiting exposed areas, surface water diversion, velocity control, slope stabilization, collection of runoff, water/solids separation, and postconstruction restoration (Sect. 2.1.4 and ANL 1987a).

\subsubsection{Hater Quality}

\subsubsection{Surface water}

Surface water quality of the streams on the ANL site could be degraded by increased erosion of soils and turbid surface runoff from the construction site. Construction plans, including safe disposal of excess excavated material, and provision of stormwater runoff ponds, are discussed in Sect. 2.1.4 (also ANL 1987a). 
Impacts of construction to surface waters would be minimized by adherence to ANL's policy on erosion and sediment control (see Sect. 4.1.1), as verified by monitoring required by ANL's NPDES permit. After construction is completed, unused disturbed areas on the site would be revegetated or restored to minimize the volume and turbidity of surface runoff. Stream turbidity (TSS), a measure of erosion and sedimentation, would be monitored at NPDES permit monitoring points on Freund Brook and Sawmill Creek. No sampling stations would be located on the drainages leading south to the Jes Plaines River, which may receive some temporary construction runoff from the on-site stormwater retention basins. Adherence to the ANL erosion control policies (Sect. 4.1.1) should preclude adverse impacts on water quality.

\subsubsection{Groundwater}

There are no significant groundwater impacts resulting from either construction or operation of APS. Groundwater recharge follows an extensive pathway through clay-rich glacial till which adsorbs soluble cations. The pathway through till would not be short-circuited, because excavations do not extend to bedrock. Clay fill removed from the excavation would be disposed of at the ANL sanitary landfill, and topsoil would be made into berms on the APS site for future usage.

The ANL sanitary landfill is designated for disposal of construction wastes from the APS site, including excess excavated soil. This landfill is surrounded by monitor wells which are completed in the glacial till. It is currently operating under IEPA Permit 1981-20-OP (Golchert and Duffy 1988). 


\subsubsection{Air Quality and Noise}

During the construction stages of APS, the principal adverse effects on air quality would result from dust and fugitive emissions of exhaust fumes. The dust would result from vehicular traffic on unpaved surfaces and from earth-moving operations. To the maximum practical extent, dust would be controlled by established engineering practices, chiefly by water sprinkling of all disturbed earth surfaces and earth stockpiles. Exhaust fumes from construction traffic and internal combustion equipment used at the construction site should be rapidly dispersed and, therefore, should not have any significant environmental effects. For both dust and exhaust fumes, any effects would be expected to be temporary and local in nature.

Sound emitted from construction equipment is also expected to be temporary and local in nature. This type of noise is specifically exempted from compliance with Illinois noise pollution control regulations (IPCB 1973, Rule 208-Exceptions). No unusual or significant noise impact is expected from construction of APS.

\subsubsection{Ecology}

\subsubsection{Terrestrial biota}

Construction of the APS facility would result in the loss of plant and animal communities of the fields, wetlands, and woodlands currently present on the proposed APS site. As noted in Sect. 4.1.1, the undeveloped area of the ANL site would decrease by approximately $15 \%$ after construction of APS. Wildlife population levels would be reduced over the long term by an amount generally proportional to the amount of habitat lost (Kroodsma 1985). Except for the fallow deer, the species that would be affected are typical of the 
surrounding region and are not particularly rare or important as game animals. Impacts on terrestrial biota would not be significant.

\subsubsection{Floodplains and wetlands}

No impacts are expected on the 100-year floodplain of Freund Brook because construction would not occur in this area (Fig. 3.8.1).

APS construction would, however, result in the filling of three small wetlands that total 0.73 ha (1.8 acres) (Areas A, B, and E, Fig. 3.8.1). These wetlands provide some wildlife habitat but are of relatively low hydrological importance (Table 3.8.1). Other, more important wetlands in the area (Areas $C$ and $F$ ) have been avoided in siting the ring, associated structures, roads, and parking lots (See Sect. 3.8.2). ANL erosion control techniques and construction fencing would protect wetlands Areas $C$ and $F$ from indirect impacts such as sedimentation. Any impacts that might occur to these wetlands would be temporary and would cease once construction was completed. Area $D$ has been filled pursuant to U.S. Army Corps of Engineers' permit (Sect. $3.8 .2)$.

There is no practical alternative site on ANL where impacts on wetlands could be avoided. Of four sites considered, two are unacceptable for the APS due to vibration effects and lack of buffer zones (Table 2.2.1). A third site has considerably more wetland that would be impacted and is thus environmentally less desirable than the proposed site.

The COE has issued a permit (permit number 26) for construction in wetlands in accordance with Section 404 of the Clean Water Act. As part of this permit, DOE would consult with the COE on the implementation of plans to mitigate wetland loss. Conceptual design for DOE's proposed mitigation plans focus on the replacement of lost wetlands, with an equivalent amount $[0.73$ ha 
(1.8 acres)] of wetland habitat created in the vicinity of the APS facility within the same watershed of the impacted wetlands. These wetlands would be designed to normally contain saturated soils to support wetland vegetation similar to that in the lost habitats (Appendix B). Soil taken from impacted wetlands would be used for the littoral zones in the new wetlands. This would provide a viable and natural seed source for most plant species currently present. Plants germinating from this seeu bank would be adapted to local conditions and should speed the establishment of wetland vegetation within the created wetlands. Detailed engineering specifications for the created wetlands would be provided to the COE before implementation. Included in this design would be consideration for ensuring rain water reaching the wetlands would be of similar quality to that which have reached the wetlands prior to the construction of the APS. Water directed to existing wetland "F" from the parking lot area riorth of the APS facility would be drained into the storm water system. This contains a four foot deep by four foot in diameter catch basin. This basin collects larger gravel and sediment. The water is then directed through an eight inch ceramic half trap to a 22 inch square water trap within the basin, similar to a baffle in a septic system, which prevents oil from leaving the basin with the water. The water then flows into detention basin "C". The flow of the water over the grass in the detention basin would filter out fines resulting in a reduced amount of suspended particles reaching wetland "F". The catch basin will be designed to meet the DuPage County Ordinance. This is sized to meet a 100 year, 24 hour storm having an intensity of 5.75 inches per 24 hours. To prevent flushing of the catch basin, a sand filter has been added to retard the flow of water. This desireable mitigation has been added to prevent impacts to the nearby wetland "F". Annual reports on vegetation and fauna would be provided to the COE for 
5 years following construction of the new wetlands. With mitigation in place, significant impacts to wetlands are not expected.

\subsubsection{Aquatic biota}

Because permanent streams are lacking on the site and the fish and invertebrate communities of Freund Brook and Sawmill Creek are relatively depauperate, there is little potential for construction impact on significant aquatic resources. Since earth-moving procedures would conform with ANL' policy (Sects 2.1.4 and 4.1.1; and ANL 1987a), impacts would be minimized, a) though some temporary increases in stream turbidity from construction site runoff could be expected during storm events. Populations of some species of aquatic biota might be temporarily reduced as a result of the increased turbidity but should subsequently recover and suffer no long-term impacts.

\subsubsection{Threatened and endangered species}

No federally listed threatened or endangered species are known to occur on the APS site (Sect. 3.8.4). An unconfirmed capture of an Indiana bat in nearby Waterfall Glen Forest Preserve indicates that this bat species may occur on ANL. A principal concern regarding the Indiana bat is the loss of streamside habitat that has a well-developed riparian forest. Because this type of habitat would not be affected by the project, the FWS has determined that the Indiana bat would not be adversely impacted (Appendix C). A question arose about the potential occurrence on the site of the Indiana bat (Myotis Sodalis), but consultation with FWS determined that suitable habitat for this species does not exist at the APS site (Appendix C). Locations tirat support the black-crowned night heron and hairy marsh yellow cress (Areas $F$ and $C$, respectively; see Fig. 3.8.1), both state-listed species, would be avcided by 
APS construction activities. Consequentiy, no significant impacts to threatened or endangered species are expected to result from construction or operation of the APS facility.

\subsection{NORMAL OPERATION IMPACTS}

\subsubsection{Surface Water Use and Quality}

Water for drinking, cooling, and other uses at the APS would be obtained from the existing ANL water supply system. Water for domestic and laboratory use at ANL is obtained from wells on the site, whereas water for process cooling is withdrawn from the Chicago Sanitary and Ship Canal (Fig. 1.2.1). Canal water usage would be limited to noncontact cooling water, free from process and other wastewater discharges. Discharge of cooling water blowdown would be via the sanitary sewer system through ANL's NPDES water effluent outfall J01. The estimated water usage for APS is compared in Table 2.1.1 with that of ANL as a whole and with the excess system capacity.

The predicted APS demand for cooling water would change total ANL cooling water usage from 1125 to $2625 \mathrm{~m}^{3} / \mathrm{d}(0.3$ to $0.7 \mathrm{Mgd})$ (Sect. 2.1.2). Cooling water blowdown would be discharged to the ANL sanitary treatment plant at a predicted rate of 380 to $1900 \mathrm{~L} / \mathrm{min}$ ( 100 to $500 \mathrm{gal} / \mathrm{min}$ ) depending on the season. The increased demand on the ANL sanitary sewer system from APS activity, including cooling water and sanitary waste, is estimated at an additional $113,600 \mathrm{~L} / \mathrm{d}(30,000 \mathrm{gal} / \mathrm{d})$. This represents an increase of only $3 \%$ of the excess capacity. Sludge generation at the sewage treatment plant from APS activity is expected to increase only an additional $3 \mathrm{~m}^{3} /$ year ( 4 cubic yards per year), which represents an additional demand of only $0.01 \%$ of the permitted disposal limit at the ANL solid-waste landfill. 
ANL currently uses $1500 \mathrm{~m}^{3} / \mathrm{d}$ ( $\left.0.4 \mathrm{Mgd}\right)$ of domestic water for a population of 3760 (Table 2.1.1). The water treatment facility has a capacity of 4540 $\mathrm{m}^{3} / \mathrm{d}(1.2 \mathrm{Mgd})$, and the anticipatied APS domestic water usage represents an increase of only $4 \%$ of the Laboratory excess capacity.

APS water consumption would have no significant effects on public communities surrounding ANL. The pumpage rates of these communities declined $10.3 \%$ from 1980 to 1985 (Sasman et 21. 1986) and are expected to continue declining as they convert from well water to Lake Michigan water usage (Pentecost 1987).

No liquid effluents from APS are anticipated other than stormwater runoff, cooling tower blowdown, laboratory drains, and sanitary wastes. Wastes such as trace amounts of organic solvents, toxic proteins, microbiological products, heavy metals, and radioactive and carcinogenic waste products would be handled in accordance with regulations and ANL waste management procedures and are not expected to pose any environmental problem. Effective restoration and landscaping of the site after construction and planned storm water runoff detention basins (Sect. 2.1.4 and ANL 1987a) should minimize the amount of sediment-laden runoff to the extent that streams would not be significantly affected during or after the plant construction phase. Conformance with the NPDES permit would also ensure that construction of the proposed APS would have little impact on water quality in Freund Brook and Sawmi11 creek.

The design capacity of $4770 \mathrm{~m}^{3} / \mathrm{d}(1.26 \mathrm{Mgd})$ for the sewage treatment plant (Table 2.1.1) is based upon an estimated ANL population of 7000 (Pentecost 1987). Current ANL population is 3760 , however, and the plant treats 1500 to $1900 \mathrm{~m}^{3} / \mathrm{d}(0.4$ to $0.5 \mathrm{Mgd})$ of sewage. The projected ANL population, after full APS operation is attained, is about 4060 full-time- 
equivalent workers (300 temporary personnel and 300 new employees). Therefore, adequate capacity is available for sewage treatment. The additional $113,600-\mathrm{L} / \mathrm{d}(30,000-\mathrm{gal} / \mathrm{d})$ sanitary sewage discharge, which includes treated cooling water blowdown from APS activities, should have no significant effect on surface water quality.

Cooling tower blowdown and sanitary wastes would be discharged to ANL's Wastewater Treatment Plant via the sanitary sewer system for treatment along with other ANL wastes before release to Sawmill Creek through NPDES outfall 001 . All cooling water additives (phosphate-based inhibitors, microbiocides, and chlorinating compounds) are biodegradable and can be treated at the Wastewater Treatment Plant. No zinc or chromate corrosion inhibitors would be used. Discharges from this plant, which has sufficient excess capacity (Table 2.1.1) to handle the APS-generated wastes, are monitored for criteria elements and other parameters to meet state of 111 inois water quality criteria and specifications of the Laboratory's NPDES permit (Golchert and Duffy 1988). Flow, pH, temperature, and TSS would be monitored at NPDES location 001 . APS cooling water discharged to the sanitary sewer system would range in temperature from $16^{\circ} \mathrm{C}\left(60^{\circ} \mathrm{F}\right)$ (winter) to $35^{\circ} \mathrm{C}\left(95^{\circ} \mathrm{F}\right)$ (summer). The maximum temperature rise above the natural temperature of the receiving stream below the NPDES outfall location 001 would not exceed permit requirements $\left[2.8^{\circ} \mathrm{C}\left(5^{\circ} \mathrm{F}\right)\right]$.

\subsubsection{Siudge Impacts}

The current average usage of canal cooling water $\left[1135 \mathrm{~m}^{3} / \mathrm{d}(0.3 \mathrm{Mgd})\right]$ generates approximately $76 \mathrm{~m}^{3}$ (100 cubic yards) of sludge per year. The sludge is removed from holding ponds once a year and is disposed of in the ANL landfi11. An additional demand of $1513 \mathrm{~m}^{3} / \mathrm{d}(0.4 \mathrm{Mgd})$ cooling water for APS 
would increase the total ANL sludge generation to a maximum of $192 \mathrm{~m}^{3}$ (250 cubic yards) per year. Sludge would be removad from the holding ponds once every 8 months. The additional increase of $115 \mathrm{~m}^{3}$ (150 cubic yards) of disposal in the ANL 1 andfill represents only a $0.5 \%$ increase in the permitted limit $\left[22,900 \mathrm{~m}^{3} /\right.$ year $(30,000$ cubic yards per year $\left.)\right]$. Sludge generated from the APS sanitary waste would increase the demand an additional 4 cubic yards per year. This represents an increase of only $0.01 \%$ in the permitted limit of the ANL landfill. The impact on ANL sludge management operations and disposal would be minimal.

\subsubsection{Power Demand}

The projected need of electric power for the proposed APS is relatively large. It amounts to 23-MVA average, with a peak demand of 34 MVA. This would represent an increase in average power demand for ANL from 15 to 38 MVA [i.e., a 15.3\% increase (Table 2.1.1)]. However, this represents only a $19 \%$ decrease in excess power capacity available at ANL. Thus, the APS power demand is not expected to significantly affect the availability of electricity in the area of Chicago and its suburbs.

Because power for APS would be obtained from an existing substation (Sect. 2.1.2), no new power lines would need to be built (i.e., no arditional land would need to be disturbed).

\subsubsection{Air and Noise Impacts}

Air impacts due to APS operation may result from car exhaust emissions and from the APS mechanical recirculating-type cooling towers. About 300 to 600 people are expected to be involved with the operation and use of APS on a continuous basis (Sect. 4.3), and they would arrive at and leave the area by 
car. Car exhaust fumes at APS would, however, constitute fugitive emissions occurring mainly at the start and closing of business. The increase in emissions from APS-relatec traffic would constitute only about $10 \%$ of car exhaust emissions at ANL. These emissions would occur over a short period of time and would rapidly disperse with insignificant additional environmental effects.

Based on experiences of similar facilities, operation of APS is not expected to generate significant amounts of gaseous or particulate emissions. During certain atmospheric conditions, moisture from APS cooling towers could cause temporary reduction of visibility in nearby (mainly on-site) roads However, a cemetery road near the APS site is not heavily traveled, and this temporary off-site impact is not expected to be significant.

Operation of APS would generate some noise, caused particularly by site traffic and by compressors and cooling towers. However, these facilities would be designed to the IIlinois State Noise Standards and DOE criteria for occupational safety and health. The effect of such noise, typical of accelerator facilities, is not considered unusual or particularly significant to raise an environmental issue.

\subsubsection{Radiological Impacts}

The primary exposure of a individual in the vicinity of APS du.ing operation would be to (gamma-ray and neutron) penetrating radiation. Shielding pianned for the facility would ensure that during normal operation the occupational external radiation dose to a worker at the highest exposure point, against the ratchet wait, on the experinientat floor for 2000 hours per year would be less than $120 \mathrm{mrem} /$ year. This is 1 ess than $2.4 \%$ of the stancard (DOE 1988b) for exposure to radiation workers. This and exposures tc sther 
individuals are based on information provided in Moe 1989b. For example, the maximum possible annual dose equivalent to an individual working with in the

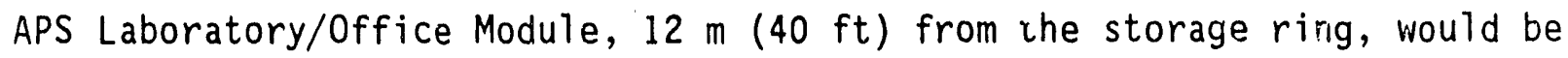
less than $6 \mathrm{mrem} / \mathrm{year}$. These are conservative estimates in that they do not include reductions for shielding by building structures that house such workers and are based on the APS running at the maximum design conditions. The above calculations are based upon 0.3 A circulating current, a energy of 7 GeV and a person experiencing operation of the machine at 2000 hours per year. Typical operating conditions would result in much lower exposures.

The annual dose equivalent to a hypothetical member of the public at the closest approach, the site boundary $140 \mathrm{~m}(462 \mathrm{ft})$ from the APS, would be approximately $6 \mathrm{mrem} / \mathrm{year}$ based on an $8000 \mathrm{~h} /$ year operation. About $2 \mathrm{mrem} /$ year would be due to direct external radiation, and $4 \mathrm{mrem} /$ year would be due to skyshine (Cho 1989b). Skyshine is radiation which is emitted upward to the sky and is scattered back to the earth by the air molecules. The nearest resident (Sect. 3.3) is $1.4 \mathrm{~km}(0.9 \mathrm{mile})$ west southwest of the APS site and could be expected to recaive less than $0.05 \mathrm{mrem} / \mathrm{year}$. Individuals in the closest subdivision, $2.1 \mathrm{~km}$ ( 1.3 miles) due northwest, could be expected to receive less than $002 \mathrm{mrem} / \mathrm{year}$. All off-site estimated doses are low compared with the DOE standard of $100 \mathrm{mrem} /$ year. Also, the dose rates estimated for the boundary, nearest resident, and closest populated subdivision are conservative in that they do not include reduction- due to shielding by residential structures or absence from the residence.

The Bicmedical X-ray Complex (ANL 1987b) is not expected to emit any more radiation than that resulting from $X$-ray facilities currently in use in hospitals. Thus, no additional dose to the public is expected from the proposed APS facility. 
Because there would be normal positron losses around the $1.104 \mathrm{~km}$ ( 0.7 mile) circumference of the accelerator, there would be some activation of components of the vacuum chamber, magnets, and other materials within the accelerator shielding enclosure. The residual radioactivity is expected to be fixed within the accelerator components inside the shielding enclosure. The activated materials would be controlled in accordance with routine ANL health physics practice to protect workers and the public.

The production rate of activated air products such as carbori-11, nitrogen-13, and oxygen-15 is estimated to be about $350 \mathrm{nCi} /\left(\mathrm{m}^{3} \cdot d\right)$ (see Sect. 2.1.3). Application of the AIRDOS-EPA atmospheric dispersion computer code gives a maximum fence-line dose of $6.0 \times 10^{-2} \mathrm{mrem} /$ year. This annual dose is extremely small compared with applicable standards for exposure and that received from natural radiation background (NC.RP 1987).

Short-lived activation products can also be produced in the cooling water but at rates about an order of magnitude lower than in air. The primary activation product in water is oxygen-15, which has about a 2-min half-1 ife. These products would result in a dose to the worker less than 1 mrem because the cooling water is in a closed system. In the event of a leak, the short half-life of this product precludes exposures to the public by all pathways.

It is planried to use gamma monitors for the entire APS system: 8 monitors for the linear accelerator, 4 for the transport line from this accelerator to the synchrotron, 16 for the synchrotron, 4 for the transport line from the synchrotron to the storage ring, and 64 for the storage ring (Pentecost 1986). Monitoring of air and water would be performed routinely at APS to ensure protection of the public. 


\subsubsection{Ecological Effects}

Operation of the proposed APS would have little potential for impact on ecological resources beyond those occurring during the construction phase. Although APS operation would cause some disturbance of wildlife in its vicinity, little additional loss of wildlife habitats is expected. The cooling towers would be relatively small and would not emit sufficient drift to affect vegetation in the area. Effective site restoration and wastewater treatment would minimize impacts on water quality (Sect. 4.2.1), thus preventing significant impact on aquatic biota. The small increase in cooling water consumption from the Chicago Sanitary and Ship Canal would not have significant entrainment/impingement effects on aquatic biota.

\subsection{SOCIOECONOMIC EFFECTS}

Socioeconomic impacts of construction and operation are evaluated. Although the construction schedule for APS is not firm, construction probably would involve up to 250 workers. As this number decreases during the last 3 years of construction, the APS technical-administrative staff would gradually increase to a stable-operation work force of about 300 persons. The total number of personnel connected with APS is not expected to exceed 600 people at any time.

Considering that a number of APS workers would transfer from existing ANL. activities to APS, the actual number of staff added to the current ANL work force of 3760 persons by APS would be relatively small (8-16\%). Most of the ANL work force lives within a $32-\mathrm{km}$ (20-mile) radius of ANL, with about $50 \%$ of these peopie iiving at disiances greater than $16 \mathrm{~km}$ (10 mijes) (ÂivL 1986). It is assumed that the additional APS work force would have the same residence 
pattern as existing employees. Since housing and services are not limited within the ANL conmuting area, no significant socioeconomic impacts are expected from the additional work force to an area that has 3.5 million people within the $32-\mathrm{km}(23-\mathrm{mile})$ radius of ANL.

\subsection{EFFECTS ON CULTURAL, HISTORICAL, AND ARCHAEOLOGICAL RESOURCES}

Under 36 CFR Pt. 800, DOE initiated consultation in 1986 with the State Historic Preservation Officer (SHPO) concerning APS construction activities that may affect cultural resources. SHPO provided technical guidelines for the cultural resource compliance work carried out in the project area. Investigation of prehistoric and historic resources located at the proposed APS site was undertaken by ANL staff archaeologists. Survey work was conducted in 1986 and 1987 field seasons to identify and determine the location of cultural resources in the APS project area. Shovel testing in wooded areas and systematic surface collecting in open areas were the survey methods used. The open areas were shallow-plowed and disked for this sampling. The study area and survey methods used are depicted in Fig. 3.4.1. Evaluation of these cultural resource sites involved additional surface collecting, mapping, limited test excavations, top soil stripping, and laboratory analysis. A three-101 ume set of reports (EES 1988) was completed and presented frr DOE and SHPO review in October 1988.

Based on their evaluation of the report (Cultural Resources at ANL's Advanced Photon Source Project Area: Volumes 1-3) (EES 1988), SHPO and DOE agreed that sites ANL-28, ANL-29, and Feature 270 associated with ANL-6 contained sufficient information to be considered eligible for the National Register of Historic Places (NRHP). DOE determined that the APS project would potentially affect the eligible sites and consulted with the Advisory Council 
on Historic Preservation (ACHP) and SHPO pursuant to the regulations (36 CFR Pt. 800) implementing Section 106 of the National Preservation Act (16 U.S.C 470). Consequent1y, DOE; ACHP, and SHPO negotiated a Programmatic Agreement (see Appendix A). The agreement stipulated that DOE would develop and implement a data recovery plan in compliance with federal regulations and laws subject to SHPO review and monitoring. This data recovery $\mathrm{plan}$ has been developed and approved by both ACHP and. SHPO. An area east of E 31850 to $E$ 32805 (Fig. 3.4.1) has also been fully evaluated for the Utility Building. This was handled under the archaeological reconnaissance survey work stipulated by the Programmatic Agreement, item 1. Further, DOE will also continue archaeological reconnaissance surveys in consultation with the SHPO of all areas of project impact not previously surveyed.

\subsection{ABNORMAL EVENTS}

In any facility, the potential always exists for the occurrence of unusual or abnormal events that may have harmful consequences on-site or offsite. In a high-voltage radiation facility such as APS, fire, lethal electric shock, and/or a radiation burst could conceivably occur.

Although the ANL site is fenced and regulated by a security force, the possibility for sabotage by dissident individuals or groups canmot be overlooked. However, ANL is engaged in R\&D and continues to maintain an open posture with respect to its endeavors. For this reason, the likelihood of sabotage on the site, and particularly at the proposed APS facility, is not considered high. In any case, any potential act of sabotage that could be sustained by APS would appear to involve only the disruption of operations but no detrimental effects to the off-site environment. 
Standard fire protection systems would be provided for APS in accordance with DOE standards except the Experiment Ha11. A separate property damage limitation exemption request has been submitted that will provide the same level of protection from fire and smoke damage and will not negatively impact the programmatic capability of the facility. The proposed fire protection system for the Experiment Hall does not in any way compromise the safety of the inhabitants and meets life safety codes. These features bring the proposed facility within the intent of DOE Order 5480.7 and ensure that all reasonable efforts have been made to reduce loss. The APS facilities pose no unusual threat, and no off-site consequences can be foreseen from typical industrial accidents and natural events such as tornadoes and earthquakes.

From the radiation standpoint, the maximum credible incident for the APS is based upon a scenario in which the positron beam with a circulating current at the maximum design capability of $0.3 \mathrm{~A}$ begins to wander as the result of erratic magnet behavior and strikes the walls of an insertion device creating Bremsstrahlung radiation (probability of this event is once in 16,000 years or less than $\left.10^{-4}\right)$. The radiation then proceeds down the optical beam line striking the lead stop in the optical beam enc'osure. The resulting radiation could shower an individual standing just beside the enclosure. The largest accidental radiation dose an occupational worker could receive from the APS facility given this condition is 1.17 rem. This dose is $23 \%$ of the applicable exposure limit of $5000 \mathrm{mrem} /$ year for workers in controlled areas (DOE 1988b). This radiation will have attenuated at $20 \mathrm{~m}(66 \mathrm{ft})$ to $7.5 \mathrm{mrem}$. At the site boundary, $140 \mathrm{~m}(462 \mathrm{ft})$ from the APS, the dose would be reduced to less than 1 mrem (i.e., less than $1 \%$ of the revised applicable standard of 100 $\mathrm{mrem} /$ year) (Sect. 4.2.4, DOE 1984 and Moe 1989b). Thus, no significant offsite (or on-site) impact frouin a radiatioñ accident may be cxpected at APS. 


\subsection{IMPACTS OF DECOMMISSIONING}

It is difficult to predict with any certainty the date for decommissioning the APS facility because of the conditions described in Sect. 2.1.5. Given this uncertainty, a detailed decommissioning plan for the APS would be developed at an appropriate time in the future. Thus, potential environmental impacts associated with APS decommissioning are discussed only yenerally in this EA. The potential APS decommissioning impacts will be fully evaluated as necessary in subsequent documentation. Generally, the potential radiological and nonradiological impacts presented in this section are derived from actual experience in the decommissioning of similar accelerators at ANL and elsewhere (Huebner 1988a).

\subsubsection{Nonradiological Effects}

Nonradiological effects associated with decommissioning work would be similar to installation of technical components during the construction phase (i.e., noise, dust, and exhaust emissions from carrier-transporting equipment, etc.) (see Sect. 4.1.3). Environmental impacts from these activities would be temporary and would have no short- or long-term effects on the site or neighboring area. No special or hazardous liquids would be required for this process. Nonradioactive solid materials would be salvaged or disposed of in a permitted sanitary landfill.

No significant impacts on site land commitment are expected. Interim space for temporary storage of excess materials could be allocated in the APS experiment hall and other support buildings. Staging areas for the preparation, packaging, and carrier-loading activities could also be accommodated within the APS facilities. 
The work force for decommissioning would be small compared with that required for construction or operation. Similarly, traffic associated with decommissioning would be no greater than for construction. Therefore, there would be no significant socioeconomic impact to the metropolitan Chicago area.

\subsubsection{Radiological Effects}

Estimates of the levels of induced radioactivity in the components of the APS facility have been made (Huebner 1988b). The dominant radioactivities would occur from activation of the iron in the magnets (Sects. 2.1.3 and 4.2.4). Most of the products would be short-lived and would decay in place during the life of the facility. At the end of a 30-year life of the project, the estimated level of intermediate- and longer-lived radionuclides would be millicurie amounts. These would be fixed within the accelerator components and would decay. The production of radionuclides in other components, such as a) uminum, concrete, and lead, would be at least an order of magnitude lower.

Decommissioning of the APS accelerator facility can be divided into two categories for radiological consideration: accelerator and shielding components that can be reused at another accelerator facility and accelerator components that cannot be reused.

Most of the decommissioned accelerator components would belong to the reusable category. Reusable components would have either nondetectable or very low activation level:. It is expected that any activation products would be fixed within the materials and, thus, that only minor surface decontamination procedures would be required. Consequently, conventional health physics control procedures for the handling of low-level radiation during storage, shipping, and reinstallation at another location are adequate to ensure no significant environmental impact. 
Nonreusable accelerator components are radiologically similar to those that can be reused but, for technical or economic reasons, disposal is the preferred option. The positron production target and shield are expected to be in this category, but they present no unique decontamination and decommissioning problems or potential for significant environmental impact. Conventional health physics surveillance and control during storage and packaging operations and shipment under DOT specifications to a DOE-approved low-level radioactive waste disposal site are adequate to limit the potential for radiation dose to the public to below permissible levels. Total radiological wastes are estimated to be less than $1.0 \mathrm{~m}^{3}$ ( 1.3 cubic yards).

Based on experience gained from the decommissioning of comparable electron accelerators at other locations in the past and of the 12-GeV Zero Gradient Synchrotron at ANL in the early 1980s, no significant environmental impact is anticipated from decommissioning operations for the APS.

\subsection{SUMMARY}

While potential impacts to wetlands and to cultural resources exist at the proposed APS site, effects of construction and operation of APS on 1 and and water quality are not xpected to be significant. Standard soii conservation measures would be used to minimize land erosion, sedimentation, dust generation, and water turbidity (Sects. 2.1.4. 4.1.1, 4.1.2 and 4.1.3). The Area $D$ pond site (Fig. 3.8.1) would bs avoided during APS construction (Sect. 3.4.1).

Operation of APS would pose a sizable demand for electric power and for cooling water from the Chicago Sanitary and Ship Canal. However, the projected total ANL demand (including APS) is only $19 \%$ of electric power excess capacity and $11 \%$ of cooling water excess capacity (Sects. 4.2.1 and 
4.2.2). Cooling tower drift is not expected to significantly affect vegetation because of the use of biodegradable additives and the relatively small size of the cooling towers.

No federally listed threatened or endangered plant or animal species are known to inhabit the ANL area (Sect. 4.1.4.4). Although there was an unconfirmed report of an Indiana bat near ANL, consultation with the FWS determined that no suitable habitat for the bat would be affected by the project (Appendix $C$ ). Locations that support state-listed species would be avoided by APS construction activities (Sect. 4.1.4.4).

Insignificant amounts of air emissions and limited noise would be expected from the APS operation. APS construction would generate fugitive exhaust emissions and noise from construction equipment, but these emissions would be limited to the construction period (Sect. 4.1.3).

Construction of APS would affect approximately 0.73 ha (?.8 acres) wetland habitat and would require a Section 404 (Clean Water Act) permit from the COE (Sect. 4.1.4.2). DOE has received a permit from the COE for construction in the wetlands. Contacts have been established with the COE to monitor mitigating actions. Mitigation plans include construction of two wetlands that would provide at least 0.73 ha $(1.8$ acres) of similar habitat to assure no net loss of wetlands at the site. These would be constructed at the beginning of the facility construction and would mimic both the physical and biological setting of the destroyed wetlands as closely as possible.

One major concern in a facility such as APS is stray penetrating (gamma or neutron) radiation. The design shielding for APS is appropriate for its siaff and also for the off-site environment, where the calculated gamma radiation dose to the nearest resident is less than $0.05 \%$ of the applicable standard of $100 \mathrm{mrem} /$ year (Sect. 4.2.5). A few short-lived radionuclides 
would be generated in air, during APS operation, at the rate of $350 \mathrm{nCi} / \mathrm{m}^{3} \cdot d$ (Sect. 4.2.5). However, air dispersion analysis shows that the dose at ANL's fence line would be insignificant $\left(6.0 \times 10^{-2} \mathrm{mrem} /\right.$ year $)$. Applications for a NESHAP permit and an air emissions permit have been submitted to the EPA and IEPA, respectively. In the event of any release of cooling water due to such events as an undetected leak, the short half-life (2 min) of oxygen-15 in the cooling water precludes a dose to the public from this pathway. APS operation plans include 96 gamma-ray monitoring stations for the accelerator system and storage ring.

No significant socioeconomic impacts are expected from the addition of a relatively insignificant work force (about $0.06 \%$ ) to the population within a 32-km (20-mile) radius from ANL (Sect. 4.3). However, construction of APS could potentially disturb some historic and archaeological sites. A Programmatic Agreement was signed by DOE (Appendix A), the I11inois SHPO, and the ACHP, by which DOE is committed to develop and implement a data recovery plan to protect cultural resources at the APS site. This plan has been developed by DOE and has been approved by the I11 inois SHPO and the ACHP. 


\section{REFERENCES}

Algermissen, S. T., Perkins, D. M., Thenhaus, P. C. Hanson, S: L., and Bender, B. L. 1982. Probabilisttc Estimates of Maximum Acceleration and Velocity in Rock in the Contiquous United States, U.S. Geological Survey, Open-File Report 82-1033.

ANL 1986. Argonne National Laboratory 1986 Long Range Facilities Utilization and Site Development Plan, Argonne National Laboratory, Argonne, I11.

ANL 1987a. 7 GeV Advanced Photon Source, Conceptual Design Peport, ANL-87-15, Argonne National Laboratory, Argonne, I11.

ANL 1987b. Biomedical X-Ray Complex, Conceptual Design Report, Document No. J9001-2001-SA-D0, Argonne National Laboratory, Argonne, I11.

Braun, E. L. 1950. Deciduous Forests of Eastern North America, The Free Press, New York.

Buhnerkempe, J. E. 1988. I11 inois Department of Conservation letter to A. L. Taboas, U.S. Department of Energy (Mar. 7, 1988).

Cheaver, C. L. 1986. Waste Handling Procedures, Argonne National Laboratory, Argonne, I11., Sept. 18, 1986

Cho, Y. C. 1989a. Argonne National Laboratory letter to R. C. Wunderlich, U.S. Department of Energy (Aug. 14, 1989).

Cho, Y. C. 1989b. Argorine National Laboratory letter to R. C. Wunderlich, U.S. Department of Energy (Oct. 12, 1989).

Coats, D. W. and Murray, R. C. 1984. Extreme Wind/Tornado Hazard Models for DOE Sites, Natural Phenomena Hazards Modeling Project, Lawrence Livermore National Laboratory, UCRL-53526.

COE 1988. U. S. Department of the Army, Corps of Enginetrs, Permit to fill the $A^{2} R^{2}$ Excavation at Argonne National Laboratory (Nov. 30, 1989)

Cowardin, L. M., et al. 1979. Classification of the Wetlands and Deepwater Habitats of the United States, U.S. Fish and Wildlife Service, FWS/OBS$79 / 31$.

Curtis, S. A., and Berlin, A. 1980. A Study of Cultural Resources at the Argonne National Laboratory, Division of Environmental Studies, Argonne National Laboratory, Argonne, 111.

Curtis, S. A., and Bebrich, C. 1. 1985. A Cultural Resource Survey of the Northgate Visitor's Reception Center Project Area, Energy and Environmental Systems Division, Argonne National Laboratory, Argonne, I11. 
Curtis, S. A., Rosentha1, M., and Stanish, C. 1985. A Cultural Resource Survey of the Lysimeter Project Area, Energy and Environmental Systems Division, Aronne National Laboratory, Argonne, Ill.

Curtis, S. A., et a1. 1987. Prel iminary Report on Cultural Resource Investigations of the APS Project Area at ANL, Argonne liutional Laboratory report, submitted to the U.S. Department of Energy.

Denmark, W. 1974. "The Climate of Illinois," in Climate of the States, Vol. 1, U.S. Department of Commerce, National Oceanic and Atmospheric Administration.

DOE 1980. Environmental Assessment Related to the Conversions of Boilers No. 1 and No. 5 at Argonne National Laboratory, prepared for the U.S. Department of Energy, DOE/EA-0126; ANL/ES-107.

DOE 1981. Requirements for Radiation Protection, U.S. Department of Energy, order 5480.1, Chap. XI.

DOE 1982. Environmental Assessment Related to the Operation of Argonne National Laboratory, Argonne, Illinois, prepared for the U.S. Department of Energy, DOE/EA-0181.

DOE 1984. Proposed Revision of DOE Order 5480.1A, Radiation Standards for Protection of the Public, U.S. Department of Energy memorandum PE-243 from R. E. Tiller to DOE Operations office managers.

DOE 1985. Review of the National Research Council Report on Major Facilities for Materials Research and Related Disciplines, A report of the Energy Research Advisory Board to the U.S. Department of Energy, DOE/S-0037 (June 1985).

DOE 1988a. Radiation Protection of the Public and the Environment, U.S. Department of Energy, Draft Order 5400.XX.

DOE 1988b. Radiation Protection for Occupational Workers, U.S. Department of Energy, Order 5480.11.

EES 1988. Cultural Resources at Argonne's Advanced Photon Source Projeci Area: Vols. 1-3, Energy and Environmental Systems Division, Argonne National Laboratory, Argonne, 111.

Eisenberger, P. and Knotek, M. L. 1984. Planning Study for Advanced Nationai Synchrotron Radiation Facilities, Sandia National Laboratory.

EPA 1977. Radiological Quality of the Environment in the United States, 1977, U.S. Environmental Protection Agency, EPA 520/1-77-009.

EPA 1980. Designation of Areas for Air Quality Planning Purposes, 40 CFR Part 81, U.S. Environmental Protection Agency, Fed. Regist. 45:6736 (Jan. $30,1980)$. 
EPA 1985. National Standards for Hazardous Air Emissions: Standards for Radionuclides, U.S. Environmental Protection Agency, 40 CFR Part 61, Subpart H.

FEMA (Federal Emergency Management Agency) 1982. Flood Insurance Rate Map, Federal Emergency Management Agency, Community Panel No. 170 197-0065-B, Panel 65 of 65, April 15, 1982.

FWS 1986. Endangered and Threatened Wildlife and Plants, U.S. Fish and Wild ife Service, 50 CFR Parts 17.11 and 17.12 .

Golchert, N.W. 1988. Argonne National Laboratory letter to R. B. McLean, Oak Ridge National Laboratory, Oak Ridge, Tenn. (Nov. 22, 1988).

Golchert, N. W., Duffy, T. L., and Sedlet, J. 1980. Environmental Monitoring at Argonne National Laboratory. Annual Report for 1979, ANL-80-29, Argonne National Laboratory, Argonne, III.

Golchert, N. W., Duffy, T. L. and Sedlet, J. 1986. 1985 Annual Site Environmental Report for Arounne National Laboratory, ANL-86-13, Argonne National Laboratory, Argonne, I11.

Golchert, N. W., and Duffy, T.L. 1988. 1987 Annual Site Environmental Report for Argonne National Laboratory, ANL-88-13, Argonne National Laboratory, Argonne, I11.

Hadley, J. B., and Devine, J. F. 1974. Seismotectonic Map of the Eastern United States, MF-620, U.S. Geological Survey, Arlington, Va.

Huebner, R. H. 1988a. Argonne National Laboratory letter to R. B. McLean, Oak Ridge National Laboratory, Oak Ridge, Tenn. (Nov. 16, 1988).

Huebner, R. H. 1988b. Argonne National Laboratory letter to R. B. McLean, Oak Ridge National Laboratory, Oak Ridge, Tenn. (Dec. 15, 1988).

IDC 1981. Endangered and Threatened Vertebrate Animals and Vascular Plants of Illinois, Illinois Department of Conservation, Natural Land Institute, Springfield.

IEPA 1985. Geographic Designations of Attainment Status of Criteria Pollutants, Illinois Environmental Protection Agency, Division of Air Pollution control.

IEPA 1986. I1linois Air Quality Report 1985, Ill inois Environmental Protection Agency, Division of Air Pollution Control, IEPA/APC/86-013 (April 1986).

IPCB 1973. Noise Pollution Control Regulations, Ill inois Pollution Control Board, Rules and Regulations, Chap. 8.

Knott, M. 1987. A Tabulation of Significant Changes Made to the Design of the APS Between February 1986 and March 1987, LS-92, Argonne National Laboratory, Argonne, 111 . 
Knowles, D. B., Drescher, W. J., and LeRoux, E. F. 1963. Ground Water Conditions at Argonne National Laboratory, 117 ino is 1948-60, U.S. Geological Survey, Water-Supply Paper 1669-0, U.S. Government Printing Office.

Kolzow, R. 1988. Argonne National Laboratory Environmental Compliance Office letter to R. B. McLean, Oak Ridge National Laboratory, Oak Ridge, Tenn. (Nov. 16, 1988).

Kroodsma, R. L. 1985. "Assessing the Loss of Wildlife Habitat in Environmental Impact Statements," Wild. Soc. Bull . 13:82-87.

LaGory, K. 1988. Argonne National Laboratory internal correspondence to R. Huebner (Feb. 4, 1988).

Lineback, J. A. 1979. Quaternary De'osits of Illinois, Illinois State Geological Survey, Urbana, I11.

Messenger, A. S., Suter, W. R., and Wagner, J. A. 1969. Ecological Survey of Argonne National Laboratory, ANL-7559.

Moe, H. J., and Veluri, V. R. 1987. Shielding Estimates for the ANL Advanced Photon Source, LS-90.

Moe, H. J. June 1989a. Dose Estimates for the $1104 \mathrm{~m}$ APS Storage Ring, LS - 139 .

Moe, H. J. September 1989b. Radiological Aspects of the ANL Advanced Photon Source, Draft LS-141.

Moore, R. E., Baes, C. F., McDowell-Boyer, L. M., Watson, A. P., Hoffman, F. 0., Pleasant, J. C., and Miller, C.W. 1979. AIRDOS-EPA: A Computerized Methodology for Estimating Environmental Concentrations and Dose to Man from Airborne Releases of Radionuclides, ORNL-5532, Oak Ridge National Laboratory, Oak Ridge, Tenn.

NCRP 1987. Ionizing Radiation Exposure of the Population of the U.S., NCRP Report No. 93, National Council on Radiation Protection and Measurements.

NOAA 1970. Tornado, National Oceanic and Atmospheric Administration, NOAA/PI 70007.

NOAA 1980. 1979 Annual Summary of Local Climatological Data, Chicago, Illinois, Midway Airport, National Oceanic and Atmospheric Administration, Environmental Data Service.

Pentecost, E. D. 1986. Argonne National Laboratory, Argonne, 111., Response to Site Visit Questions, formal letter to E. Ricci, Oak Ridge National Laboratory, Oak Ridge, Tenn.

Pentecost, E. D. 1987. Argonne National Laboratory, Argonne, 111., formal letters to E. Ricci and R. B. McLean, Oak Ridge National Laboratory, Oak Ridge, Tenn., providing requested information (Apr. 15, May 19, and Nov. 9, 1987). 
Reinsch, L. J. 1986. Policy on Construction Project Erosion and Sediment Control, Argonne National Laboratory, Intra-Laboratory Memo (January 7 , 1986).

Sasman, R. T. 1974. "The Future of Ground Water Resources in DuPage County," Ground Water 12 (5), September-October 1974.

Sasman, R. T., et al. 1981. Verification of the Potential Yield and Chemical Quality of the Shallow Dolomite Aquifer in Du Page County, Illinois, Illinois State Water Survey, Circular 149, Champaign, I11.

Sasman, R. T., et al. 1986. Water-Level Trends and Pumpage in the Cambrian and Ordovician Aquifers in the Chicago Region, 1980-1985, Circular 166, Illinois State Water Survey, Champaign, I11.

Seitz, F., and Eastman, D. 1984. Major Facilities for Materials Research and Related Disciplines, Chairman, National Academy of Science, Washington, D.C.

SLAC 1988. Health Physics Manual of Good Practices for Accelerator Facilities, Stanford Linear Accelerator Center, U.S. Department of Energy, SLAC-Report-327.

Soil and Material Consultants, Inc. 1986. Geotechnical Investigation, $6 \mathrm{GeV}$ Synchrotron $X$-Ray Source, report to Argonne National Laboratory, File No. 8799, Preliminary Draft.

Smith, P. W. 1971. Illinois Streams: A Classification Based on Their Fishes and an Analys is of Factors Responsible for Disappearance of Native Species, Illinois Natural History Survey Biological Notes No. 76.

Suter, M., et a1. 1959. Preliminary Report on Ground-Water Resources of the Chicago Region, Illinois, Illino is State Geological Survey, Cooperative Ground-Water Report I, Urbana, III.

Swanson, W. P. 1979. Radiological Safety Aspects of the Operation of Electron Linear Accelerators, Technical Report Series No. 188, International Atomic Energy Agency, Vienna, Austria.

Title I, 1989. Advanced Photon Source: Title I Design Report Appendix G, Trade off Studies, Lester B. Knight and Associates Inc., Chicago, I11.

USDA 1979. Soil Survey of Du Page and Part of Cook Counties, Illinois, U.S. Department of Agriculture, Soil Conservation Service, in cooperation with the Illinois Agricultural Experiment Station, Urbana, 111.

Vaughan, W. A. 1985. Memorandum to distribution, "Radiation Standards for Protection of the Public in the Vicinity of DOE Facilities," EH-24 U.S. Department of Energy (Aug. 5, 1985). 


\section{LIST OF PREPARERS}

This environmental assessment was prepared for the U.S. Department of Energy by the Integrated Analys is and Assessment Section, Energy Division, Oak Ridge National Laboratory (operated by Martin Marietta Energy Systems, Inc., for the U.S. Department of Energy). The following members of the ORNL technical staff contributed to this task:

R. B. McLean; Ph.D., Marine Biology; Program Manager

E. Ricci; Ph.D., Chemistry; APS EA 'roject Leader

R. L. Kroodsma; Ph.D., Zoology

R. L. Miller; M.S., Meteorology

W. P. Staub; Ph.D., Geology/Soils Engineering

J. P. Witherspoon; Ph.D., Plant Ecology (radiological effects)

M. Swihart; M.S., Landscape Architecture 


\section{Appendix A}

PROGRAMMATIC AGREEMENT REGARDING CULTURAL RESOURCES AT ANL'S ADVANCED PHOTON SOURCE SITE, AND ATTENDANT CORRESPONDENCE BETWEEN THE ILLINOIS HISTORIC PRESERVATION AGENCY AND THE U.S. DEPARTMENT OF ENERGY 


\title{
PROGRAMMATIC AGREEMENT
}

\author{
AMONG THE U.S. DEPARTMENT OF ENERGY, \\ THE ADVISORY COUNCIL ON HISTORIC PRESERVATION, AND \\ THE ILLINOIS STATE HISTORIC PRESERVATION OFFICER \\ FOR THE ADVANCED PHOTON SOURCE PROJECT \\ AT ARGONNE NATIONAL LABORATORY
}

WHEREAS, the Department of Energy (DOE) proposes to construct and operate the advanced Photon Source at the Argonne National Laboratory, DuPage County, Illinois, and

WHEREAS, the DOE has determined that this project will have an effect upon properties eligible for listing on the National Register of Historic Places, and has consulted with the Advisory Council on Historic Preservation (Council) and the Illinois State Historic Preservation Officer (SHPO) pursuant to Section 800.13 of the regulations ( 36 CFR Part 800 ) implementing 106 of the National Historic Preservation Act (16 U.S.C. Section 470f);

NOW, THEREFORE, the DOE, the Illinois SHPO, and the Council agree that the project shall be implemented in accordance with the following stipulations to satisfy the DOE's Section 106 responsibilities for the project.

\section{Stipulations}

The DOE will ensure that the following measures are carried out.

\section{ARCHAEOLOGICAL SURVEY}

A) The DOE shall ensure that an archaeological reconnaissance iurvey (Phase I) will be performed in all project areas which have not already been surveyed. An archaeological intensive survey (Phase II) will be performed at all historic properties identified during the reconnaissance survey. These surveys will be conducted in a maraer consistent with the Secretary of the Interior's Standards and Guidelines for Identification (48 FR 44720-23) and taking into account the National Park Service publication The Archaeological Survey: Methods and Uses (1978) and the Illinois State Historic Preservation Office Guidelines for Archaeological Reconnaissance Surveys/Reports. The survey shall be conducted in consultation with the Illinois SHPO, and a report of the survey, meeting the standards of the Illinois SHPO, shall be submitted to the Illinois SHPO for review and approval. 
B) In consultation with the Illinois SHPO, the DOE shall evaluate properties identified through the survey against the National Register criteria (36 CFR Part 60.4). For those properties which the DOE and the Illinois SHPO agree are not eligible for inclusion in the National Register of Historic Places, no further archaeological investigations will be required, and the proposed project may proceed in those areas. If the survey results in the identification of properties that the DOE and the Illinois SHPO agree are eligible for the National Register, such properties shall be treated in accordance with Part II below. If the DOE and the Illinois SHPO do not agree on National Register eligibility, or if the Council or the National Park Service so request, the DOE shall request a formal determination of eligibility from the Keeper of the National Register, National Park Service, whose determination shall be final.

\section{ARCHAEOLOGICAL DATA RECOVERY (Phase III)}

A) Archaeological sites which are considered eligible for the National Register, including sites $A N L-28, A N L-29$, and Feature 270 associated with site ANL -6 , will be treated in the following manner:

1. The DOE shall ensure that a data recovery plan addressing substantive research questions is developed in consultation with the Illinois SHPO for the recovery of relevant archaeological data. The plan shall be consistent with the Secretary of the Interior's Standards and Guidelines for Archaeological Documentation (48 FR 44734-37) and take into account the Council's publication, Treatment of Archaeological Properties. It shall specify, at a minimum, the following:

0 the property, properties, or portions of properties where data recovery is to be carried out;

0 the research questions to be addressed through the data recovery, with an explanation of their relevance and importance;

0 the methods to be used, with an explanation of their relevance to the research questions;

0 proposed methods for disseminating results of the work to the interested public; and

0 a proposed schedule for the submission of progress reports to the DOE and the Illinois SHPO.

2. The data recovery plan shall be submitted by the DOE to the Illinois SHPO for fifteen (15) days review and approval. After approval, the DOE shall then ensure that the data recovery plan is implemented. The Ilitinois SHPO shall monitor this implementation. If within fifteen (15) days of receipt of the plan, the Illinois SHPO has not responded, the DOE shall implement the data recovery plan as submitted. 
B) The DOE shall ensure that the data recovery plan is carried out by or under the direct supervision of an archaeologist(s) who meets, at minimum, the Secretary of the Interior's Professional Qualifications Standards (48 FR 44738-9).

C) The DOE shall ensure that adequate laboratory time and space are available for analysis of osteological, cultural, and biological materials recovered from the excavations.

D) The DOE shall ensure that an adequate program of site security from vandalism during data recovery is developed in consultation with the Illinois SHPO, and then implemented by the DOE.

\section{CURATION AND DISSEMINATION OF INFORMATION}

A) In consultation with the Illinois SHPO, the DOE shall ensure that all materials and records resulting from the data recovery conducted at Argonne National Laboratory are curated at a repository within the state of Illinois and in accordance with 36 CFR Part 79. If human remains are recovered, the signatories to this Agreement shall consult further to determine the appropriate disposition of the remains.

B) The DOE shall ensure that all final archaeological reports resulting from actions pursuant to this Agreement will be provided in a format acceptable to the Illinois SHPO, and to the National Park Service for possible peer review and submission to the National Technical Information Service (NTIS). The agency official shall ensure that all such reports are responsive to contemporary standards, and to the Department of the Interior's Format Standards for Final Reports of Data Recovery Programs (42 FR 5377-79). Precise locational data may be provided only in a separate appendix if it appears that its release could jeopardize archaeological sites.

\section{DISPUTE RESOLUTION}

The DOE and the Illinois SHPO shall together attempt to resolve any disagreement arising from implementation of this Agreement. If the DOE determines that the disagreement cannot be resolved, the DOE shall request the further comments of the Council in accordance with 36 CFR Part $800.6(\mathrm{~b})$. Any Council comment provided in response will be taken into account by the DOE in accordance with 36 CFR Part $800.6(\mathrm{c})(2)$, with reference only to the subject of the dispute. The DOE's responsibility to carry out all actions under this Agreement that are not the subjects of the dispute will remain unchanged. 
Execution and implementation of this programmatic Agreement evidences that the

Department of Energy has satisfied its Section 106 responsibilities for 11

individual undertakings of the project.

ADVISORY COUNCIL ON HISTORIC PRESERVATION

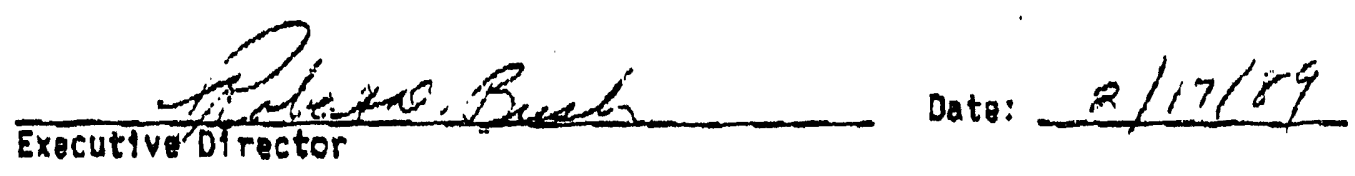

ILLINOIS STATE HISTORIC PRESERVATION OFFICER

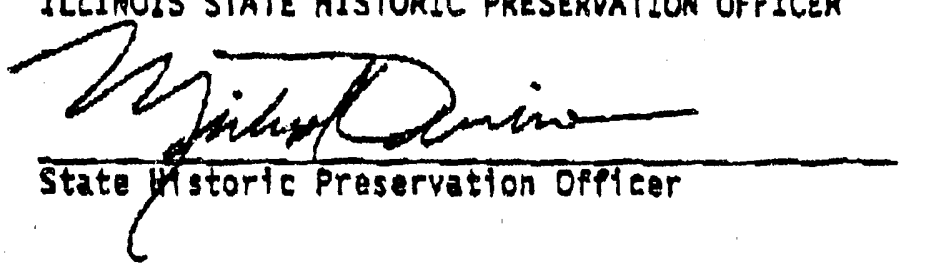

Date: $2-14-89$

DEPARTMENT OF ENERGY

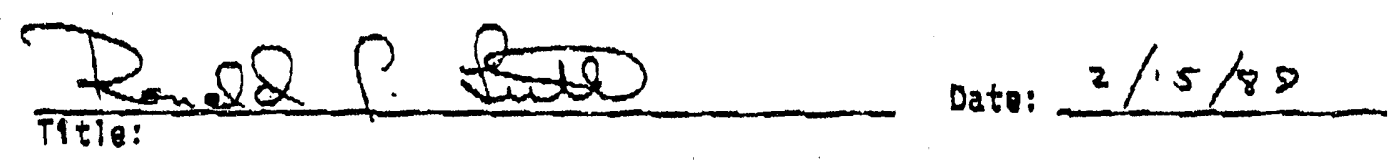

$$
\begin{aligned}
& \text { RONALD S. LUTH } \\
& 2 \text { GOV PROJECT MIANGGE }
\end{aligned}
$$




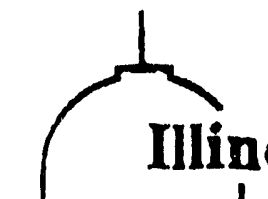

\section{Illinois Historic}

\section{Preservation Agency}

Old State Capitol • Springfield, Illinois 62701 • (217) 782-4836

$217 / 785-4512$

November 1, 1988

Mr. Ronaid J. Lutha

7 GeV Projece Menager

Advanced Photon Source

Department of Energy

Argonne Area Offlce

9800 South Cass Avenue

Argonne, IL 60439

Dear Mr. Lutha:

Our staff has reviewed the cultural resources documentation presented in your report Cultural Resources at Aroonne's Advanced Photon Source Protect Area: yolumes $1-3$ and in our meeting/fleld Inspection at Argonne Lab on 7 October, 1988. 8ased upon that information it is our opinton that three of the investlgated properttes, 1.a. ANL 28, ANL 29, and Feature 270 with assoclated area ANL 6. contain sufficlent information to be considered eligibio for the Natlonal Reglster of Historte Places.

1) Historlc archaeological site ANL 28 represents an inftial early $1840-1850$ occupation by Irtsh laborers who, by the $1870^{\prime} \mathrm{s}$. were absorbed into the larger agrarian community. This sita contains our first opportunity to examine the archaeological aspects, at the household-level, of the social and econonic impact of the construction of tho Illinois and Michigan Canal in northeastern Illinols. It provides a unlque opportunity to examine the transformation of the material culture as the economie focus of the houshold changed from that of a laborar to that of a farmer. In our opinton, ANL 28 possesses sufficent archaeological sfgniflcance for listing on the National Register of Historic Places under criterion $d$.

2) Historlc archaeological site ANL 29 represents an early mid-nineteenth century farmstead whose high degroe of integrlty will provide important insights into the development of the agrarian economic pattern in the greater Chicago area durlng the heyday of the Illinots and Michigan Canal. This site is especially important as a comparative base for developing a perspective on the materlal culture of such agrarlan householo when constdered in conjunction with ANL 28. In our opinion ANL 29 possesses sufficent archaeological signlficance for listing on the National Register of Historlc Places under critertion $d$. 


\section{Page 2}

3) Feature 270 represents a late prehlstoric or early protohistoric earthworks radiocarbon dated to the 16 th century. Chronologicaliy and culturally, this ditch feature would appear to be related to the late Upper Mississippian mantfestattons in the greater Chlcago area. This untque feature can provide crittcal informatton on a poorly understood pertod in Illinots' archacological record. In our opinton. Feature 270 and 4 ts assoclated area ANL 6 possesses sufficant archaeological significance for 11 sting on the National Register of Historic places under crlterton d.

In our opinion. the level of documentation also demonstrates that prehistoric sites ANL 4 and ANL 23 do not possess sufficent intergrity or contain adequate information to be considered ellgtble for the Nattonal Register of Alstoric Places. It is necessary, however, that analysts of the materlals from these sites be completed as part of the Phase II report process.

If the Department of Energy agrees with our findings that ANL 28, ANL 29 and Feature 270 and associated area ANL 6 are eligible for the National Register of Historlc Places, this concurrence should be stated in a lotter to our offtce as soon as possible. Under 36 CFR Part 800.4 (C) in cases where the SHPO and the Federal Agency concur. "the propertfes shall be considered eligible for the National Register for Section 106 purposes."

Additionally, it is our opinton that the construction of the Advanced Photon Source Profect at Argonne National Laboratory will have an adverse effect on these elfgible cultural resources. To mitigate the profect 1 mpact on the resources we suggest that the Department of Energy and the Illinots SHPO enter into a Memorandum of Agreement (MOA) detalling a procedure to take into account these effects pursuant to 36 CFR Part $800.5(\mathrm{e})(4)$. Please note that we have provided a space por the signature of a representative of the Argonne National Laboratory to sign as a concurring party. We have attached such a MOA for your purusal and signature.

If the Department of Energy flinds the enclosed MOA sultable. a signed copy accompanted by the documentation specteled in 36 CFR Part $800.8(b)$ and $(c)$ should be forwarded to the Advisory Council on H1stortc Preservation (The Old Post Offlce Bullding, 110 Pennsylvanta Avenue, NW, \#809, Washington, D.C. 20004) for thetr review. 


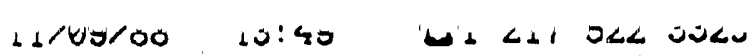

Lrigına, Copy lo

$40610 / 006$

$\rightarrow-$

Page 3

If you have questions on the process or require additional information. please contact Thomas E. Emerson. Chief Archaeologist at the above referenced number.

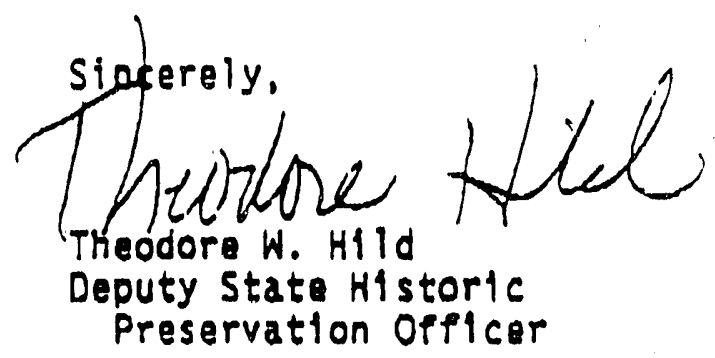

TH : TEE

Enclosed: MOA

bc: Betsy Updike Ted Hold 


\section{Appendix B}

\section{WETLANDS PERMIT AND}

ATTENDANT CORRESPONDENCE AMONG THE

U.S. ARMY CORPS OF ENGINEERS, THE ILLINOIS ENVIRONMENTAL

PROTECTION AGENCY, THE U.S. DEPARTMENT OF ENERGY, AND

ARGONNE NATIONAL LABORATORY 

Mr. James E. Evans, P. E.

Ciliei, Construction Operations Divizion

i.j. Aruy Corps of Engineers

111 i. Canal street

Chicajo, Illinols 60604

Dear vir. Evans:

ZUDJECT: ADVANCED PHOTCN SCURCU WETLAHD MIEIGATION PLAN

In order to further coordinate efforts between the Department of Ënergy (DCrit and the Lorps of Engineers (COE) on the Advance Photon Source (APS) Sectiun tu't perait, I wouid like to advise you at this time of recent developments if the APS coustruction pians. As Consraace Hunt of your staff is arara Erod recent telephone conversations with Ron Lutina of this office, Titla I Desion Prelininary Engineering, has been developed for the APS. The AFS ring has shticed 270 teet to the south and 100 ieet to the west in orter co reduce til ancunt of excavations for the fing and to take advantage of a nore stanto subsurtace condiciun. To reduce possible project impact on wovded areas at the north end of the site the structure was rotated 21 jegrees clockwise. Because of this shifting of the rlaj, nOE has revisited the conceptual weta witigation plan incorporated in the Section 104 ationwide perit issued by COE to DOE on February 2, 1989.

Atraciment I contains a Title I drawing of the slte, and where the proposed

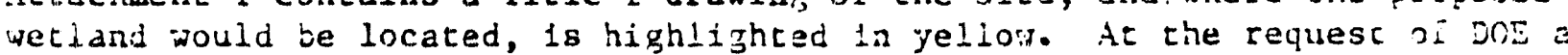
Argonne iational Laboratory (ANi), Dr. Courtney ilacilley, onr wetlands consultant, reviewed rie prubable changes rasulting : Lom the fitle I Desion. Attachment 2, contains a copy of Dr. Courtney Hackney's letter to Atit, where he recomends and outlines the current pians for creating the proposed wethands.

DOE beiieves that the results of the Title I Design effurt are consicient wit the Section 404 permit approved by your office. The sane total arreage o: werlands will be replaced in the south central section of the AP's site. However, instead of recreating two very small wetlands, one wetland of 1.3 acres will be created. DOE Intends to honor all otiter comratments such as protection of Wetland $C$, the eariy construction of tie replacement vetland, and monitorinis the newly created wetland for five guars. 
Please confirm in writing that the DOE is still in compliance with the Sect SONGURRENCES 404 permit approved by the COE on February 2, 1989. If you have any questidns. sYMBoL please feel free to give me a call on (312) 972-2366 or Ron Lutha on (312) 972-2432. As outlined in the permit, we will seek your approval of our Tit II design (Definitive Design) of the proposed wetlands upon completion, prid to construction.

Enclosures:

Sincerely,<smiles>CCCCCCCC1CCC1(C)C</smiles>

Robert C. Wunderlich

Project Manager

$7 \mathrm{GeV}$ Advanced Photon Source

As Stated

cc w/encls: Y. Cho, ANL

R. HISIOP, ANL

bc w.encls: G. Walach, OCC

M. Grace, ESHD

B. White, ESHD

File: $\quad 4710.10 .5 .2$ 


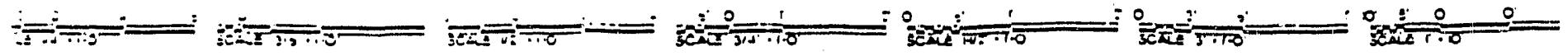

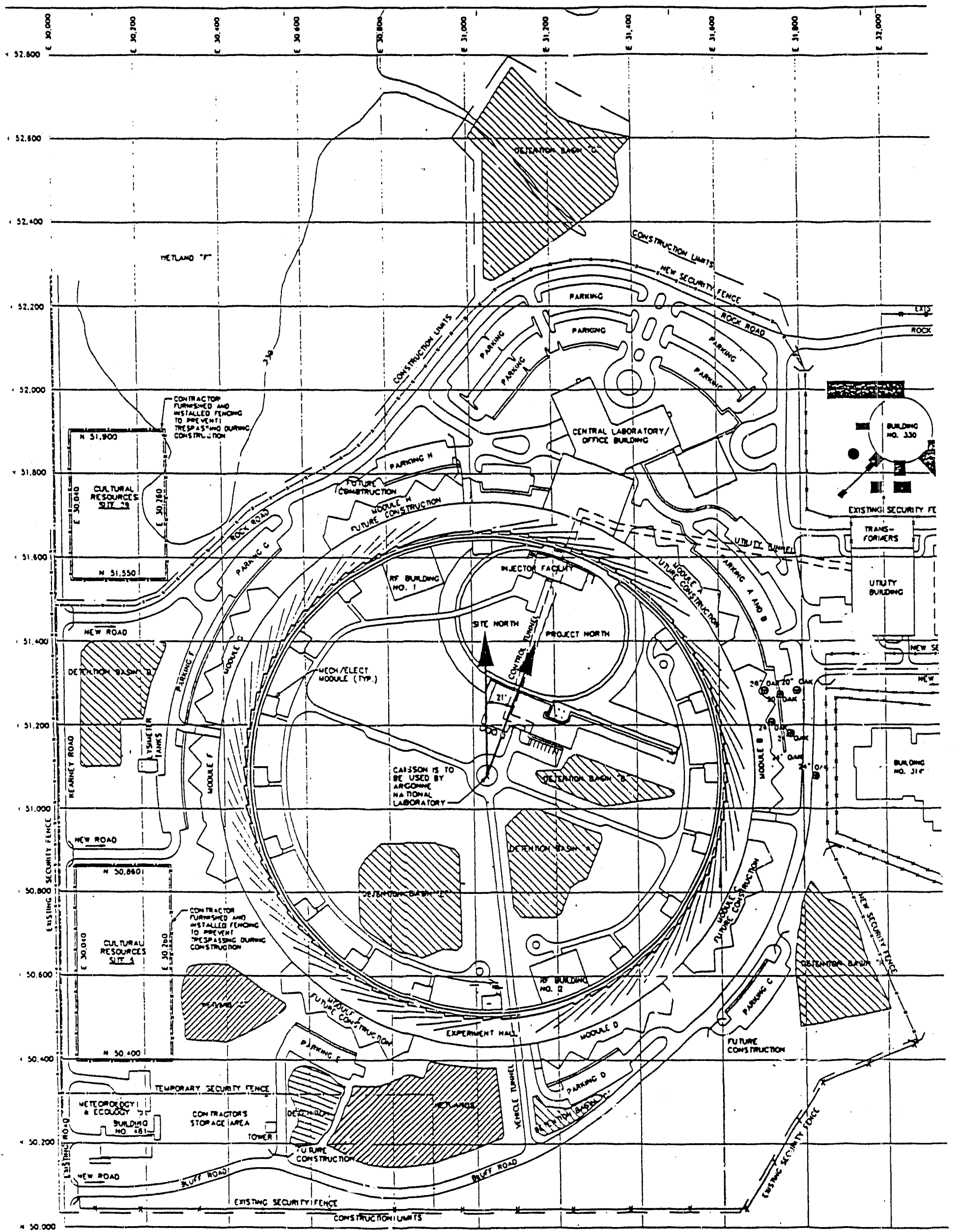


COURTNEY T. HACKNEY, PH. D.

Coastal Ecologist - Wetland Consultant

ROUTE 1. BOX 382R

ROCKY POINT. NORTH CAROLINA 28457

(919) $259-3348$ or (919) 395-3759

\section{Seftember 1Sag}

Mr. Richard D. Hislop

AFS, Bld $3 E D$

As acnne National Lac

g7og South Cass Ave

Assonne, II 69439-4914

Dear Mr. Hi $\equiv$ lof,

Uuring my visit to the froposed AFS sitio on 7 \& 9 sectember 1989, I examined the impart of moving the flanned strueture on the 484t fermit obtained from the Corps of Engineers. Since construetion plane are further along now, I also discusead construetion aspects of the wetland with Mr. John MeKinnon from the Architerture and Enginesering firm of LEster $E$. Knight and Assoriates. The prime cuestion you askad me to examine was if moving the strueture sudth altered the conditions or validity of the COE 404 Fermit.

The frimary chences relative to the permit are 1) the construction of one 1.85 acre wetland instead of two equal to the Eame $a r \equiv \equiv$, 2) a change in the manner through which water will enter the created wetland and 3 i some fotential change in the size of the buffar zone araund the newly constructed wetland and wetland $c$. The numerous detention are another refinement in construetion plans which were not a fart of the permit, but nesd to be mentioned. These will retein heavy prerifitation and release it slowly until they do not contain standing watser. These are required by currant county regulations.

The current $p l a n$ ij to fencE wetland $c$ before site preparation begins with a 30 font buffer zone and affropriate erosion control measures. No fill will enter the nitural area. There may be one part af this bufier zone, aloris the northern Eide, which may not be $39^{\prime}$ wide. All other construetion plaris follow the origina! fermit seerifications.

Flans for the watland to be constructed as mitigation for wetlands $A$ \& $E$ can now be finalized. Eince we had no final site plan when the original permit was granted this part of the plan must sti l, be submitted to the COE. It was understood that there would be some changes from the oriainal frofosel. This wetland will be construeted in the eouth centrel portion of the construetian area and will include 1.55 acres of the lowest 
contour. Soil from wetlands $A$ \& $B$ will be placed in this wetland as soon as it is removed from wetlands $A$ \& $B$. It will not be stockpiled. This is the most desired situation. The water necessary to froduce and maintain this wetland will come from the southern half of the inside grassed perimetar of the AFS etructure. This portion of the APS site will be graded and planted with grass before conetruetion of the AFS facility begins. Water will fill a detention basin within the perimetar and be fed slowly into the eanstrueted wetland. There should be little difference between the water guality of this water versus water from the watershed surrounding the APS structure. The mitigated wetland would be fenced and proterted from siltation. A $39^{\prime}$ buffer ma', not always be fosible during censtruction, but the basin will be froterted at all times from siltation.

Detention pands built to control Etorm runeif, Elthough not a part oi any COE jermiti will be enginesied essentially es intarmittent wetlands excert for basin $H_{\text {. }}$ Detention basin $H$ will contain a shallow fond. This aspert was added to frovide tresding areas for emphibians,

Wetland $E$, for which the created wetland was fartly mitieated will now be a retention basin. This is a very desirableplan as it will lessen the imfact of etorma on the wetland $F$. I understand thet the basin will be construetsd by excavation. This is acreotable, but if a dam is uEEd instesd of excavation the COE should be corisulted.

A five year maritoring of the created wetland remaina a part ot the permit. Should the engineering design not mest COE eriteria they retain the right to cancel the permit. I would aljo sugsest that if construetion of the AFS facility takes mor than five years the monitoring program should also be extended.

It is my opinion that the eonstruction changes should not imferile the viability of the 404 permit as these changes Eetuall lessen overall environmental imfacts on the adjacint

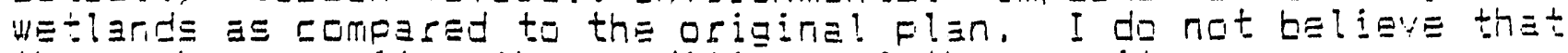
these ehanges alter the conditions of the fermit.

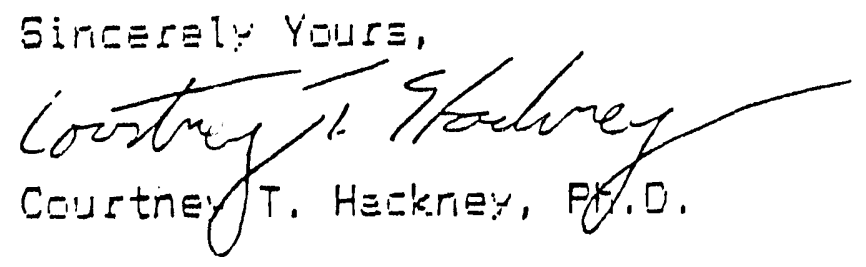




\section{DEPARTMENT OF THE ARMY \\ CHICAGO DISTRICT, CORPS OF ENGIPEERS \\ 219 SOUTH DEAREORN STREET \\ CHICAGO, ILLINOIS 60604.1797}

2 FES 1989

REPLY TO

ATTENTION OF

Regulatory Functions Branch

1708901

SUBJECT: Proposed Construction of the Advanced Photon Source at Argonne National Laboratory, DuPage County, Illinois

Mr. Ronald J. Lutha, Project Manager

Department of Energy

Argonne Area Office

9800 South Cass Avenue

Argonne, Illinois 60439

Dear Mr. Lutha:

This letter is in regards to the filling of wetlands at the site of the proposed Advanced Photon Source. We have determined that this project, including the mitigation plan submitted on January 26, 1989 , qualifies for authorization under an existing nationwide permit. This determination is contingent. upon review of the final engineering drawings and management and monitoring plan for the mitigation site by our office. We would like to have tiwo weeks to review these documents before you commence work on the site.

We have received the November 22 , 1988 Section 401 water quality certification issued by the Illinois Environmental Protection Agency (IEPA) for your project. A copy of the IEPA 401 certification and the nationwide permit conditions and management practices that you must comply with are enclosed.

This determination is applicable only to the permit program administered by the Corps of Engineers. It does not eliminate the need to obtain other federal, state or local approvals before beginning work. You are advised that this verification of the 
nationwide permit authorization is valid for two years from the date of this letter. If you have any questions, please contact Ms. Constance Hunt of the Regulatory Functions Branch, telephone number 312/353-6491.

\section{Sincerely,}

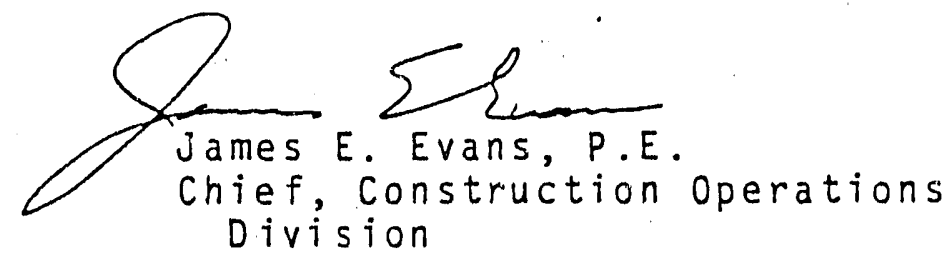

Enclosures $(A, 26,401)$

iopy Furnished

IDOT/OWR (Kabbes)

IEPA (Yurdin) 
1. Discharges of dredged or fill material into waters of the United States shall be avoided or minimized through the use of other practical alternatives.

2. Discharges into spawning areas during spawning seasons shall be avoided.

3. Discharges shall not restrict or impede the movement of aquatic species indigenous to the waters or the passage of normal or expected high flows or cause the relocation of the water unless the primary purpose of the fill is to impound waters.

4. If the discharge creates an impoundment of water, adverse impacts on the aquatic system caused by the accelerated passage of water and/or the restriction of its flow shall be minimized.

5. Discharges into wetland areas shall be avoided.

6. Heavy equipment working in wetlands shall be placed on mats.

7. Discharges into breeding areas for migratory waterfowl shall be avoided.

8. All temporary fills shall be removed in their entirety. 


\section{NATIONWIDE PERMIT $330.5(a)(26)$ CONDITIONS}

DISCHARGES OF DREDGED OR FILL MATERIAL INTO: NON-TIDAL RIVERS, STREAMS, AND THEIR LAKES AND IMPOUNDMENTS, INCLUDING ADJACENT WETLANDS, THAT ARE LOCATED ABOVE THE HEADWATERS; AND OTHER NON-TIDAL WATERS OF THE UNITED STATES, INCLUDING ADJACENT WETLANDS, THAT ARE NOT PART OF A SURFACE TRIBUTARY SYSTEM TO INTERSTATE WATERS OR NAVIGABLE WATERS OF THE UNITED STATES ( $i . e$. ISOLATED WATERS)

1. That the Illinois Environmental Protection Agency has issued water quality certification for the discharge under Section 401 of the Clean Water Act.

2. That any discharge of dredged or fill material will not occur in the proximity of a public water supply intake.

3. That any discharge of dredged or fill material will not occur in areas of concentrated shellfish production.

4. That the activity will not jeopardize a threatened or endangered species as identified under the Endangered Species Act, or destroy or adversely modify the critical habitat of such species.

5. That the activity will not significantly disrupt the movement of those species of aquatic life indigenous to the waterbody.

6. That any discharge of dredged or fill material will consist of suitable material free from toxic pollutants in toxic amounts, pursuant to section 307 of the Clean Water Act.

7. That any structure or fill authorized will be properly maintained.

8. That the activity will not occur in a component of the National Wild and Scenic River System.

9. That the activity will not cause an unacceptable interference with navigation.

10. That, if the activity may adversely affect historic properties which the National Park Service has listed on, or determined eligible for listing on, the National Register for Historic Places, the permittee will notify the district engineer.

11. That the best management practices Iisted on Attachment A shall be followed to the maximum extent practicable.

If the above conditions cannot be met an individual or regional permit will be required. 
$27 \overline{7 / 732-1696}$

D.0.E. Argonne National Laboratory (DuPage Co:)

Hetland Fill - DesPlaines River Watershed

Log \#C - 945-88 [CoE Appl. \#1708901]

November 22, 1988

Department of the Army

Chicago District

Corps of Engineers

219 South Dearborn Street

Chicago, I7linois 60604

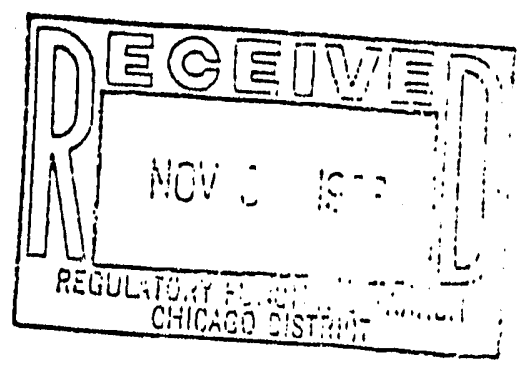

Gentlemen:

This Agency received a request on October 20, 1988, from the U:S: Department of Energy requesting necessary comments for environmental consideration concerning the construction of the 7-GeV Advanced Photon Source (APS) at Argonne National Laboratory in DuPage County. The construction of the APS will result in the filling of approximately $1: 1$ acres of wetland. We offer the following comments:

Based on the information included in this submittal; it is our engineering judgment that the proposed project may be completed without causing water poliution as defined in the Illinois Environmental Protection Act, provided the project is careiulty planned and supervised:

These comments are directed at the effect on water quality of the construction procedures involved in the above described project and is not an approval of any discharge resulting from the completed facility; nor an approval of the design of the facility. These comments do not supplant any permit responsibilities of the applicant towards this $f$ iancy.

This Agency hereby issues certification under Section 401 of the Clean Water Act (PL 95-217); subject to the applicant's compliance with the following conditions:

1. The applicant shall not cause:

a. Violation of applicable water quality standards of the Illinois Pollution Control Board, Title 35; Subtitle C: Water Pollution Rules and Regulations;

b. water pollution as defined and prohibited by the Inlinois Envi ronmental Protection Act; and

c. interference with water use practices near public recreation areas or water supply intakes.

2. The applicant shall provide adequate planning and supervision during the project construction period for implementing construction methods, processes and cleanup procedures necessary to prevent water pollution and control erosion. 
Page 2

3. Any spoil material excavated, dredged or otherwise produced must not be returned to the waterway but must be deposited in a self-contained area in compliance with all State statutes; regulations and permit requirements with no discharge to the waters of the State uniess a permit has been issued by this Agency. Any back filling must be done with clean material and placed in a manner to prevent violation of applicable water quality standards.

4. All areas affected by construction shall be mulched and seeded as soon after construction as possible. The applicant shall undertake necessary measures and procedures to reduce erosion during construction. Interim measures to prevent erosion during construction shall be taken and may include the installation of staked straw bales, sedinentation basins and temporary mulching: A11 construction within the waterway sha17 be conducted during zero or low flow conditions:

5. This certification becomes effective when the Department of the Army; Corps of Engineers; inciudes the above conditions $\frac{\|}{7} 7$ through 4 as conditions of the requested permit issued pursuant to Section 404 of PL: 95-217.

This certification does not grant inmunity from any enforcement action found necessary by this Agency to meet its responsibilities in prevention, abatement, and control of water pollution:

Very truly yours;<smiles></smiles>

Thomas G. MCSwiggin, P.E: Manager; Permit Section

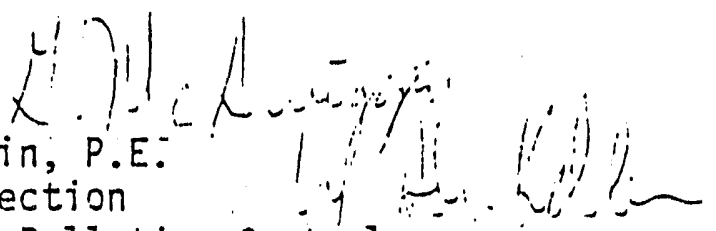
Division of Water Pollution Control

TGil: JH:jab/3636j/21 -22

CC: IEPA, DWWP, Records Unit

DWPC, Field Operations Section; Region 2

IDOT, Division of Water Resources, Schaumberg USEPA, Region $V$

D.O.E. Chicago Operations Office/Argonne Area Office 
November 2, 1988

U.S. Department of Energy

Chicago Operations office

Argonne Area Office

9800 S. Cass Avenue

Argonne, II 60439

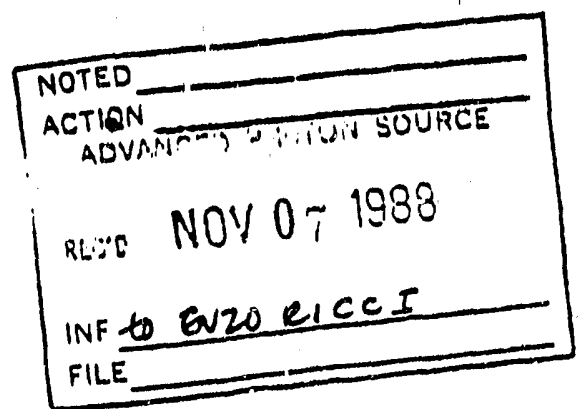

Attn: Ronald Lutha

Dear Applicant:

$$
\text { Advanced Photon Source - Argonne - DuPage County }
$$

Thank you for your application for permit, submitted on your behalf by Ronald $J$. Lutha for the above referenced project in the Southwest I/4 of Section 9, Township 37 North, Range 11 East of the 3rd Principal Meridian in DuPage County.

An Illinois Department of Transportation, Division of water Resources' Demit is not required for the project as both of the following conditions are met:

a). The project site is not located within a designated floodway.

b). The project site is not located, within the flood plain of a watercourse that drains at least one square mile in an urban/urbanizing area or at least 10 square miles in a rural area.

This letter does not exempt the project from meeting the requirements of any other local, state, or federal agency.

If you have any questions, please call Gary Jereb of my Schaumburg office staff at 705-4341.

Sincerely,

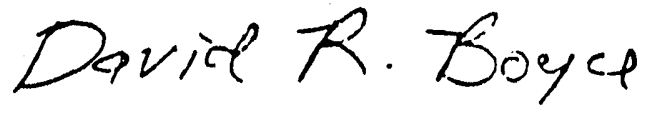

David R. Boyce, P.E.

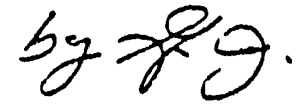

Chief Flood Plain Management

Engineer

cc: Chicago Corps of Erigineers

IDPA

DuPage County

$\mathrm{DRB} / \mathrm{KCK} / \mathrm{GJ}: \mathrm{tj}$

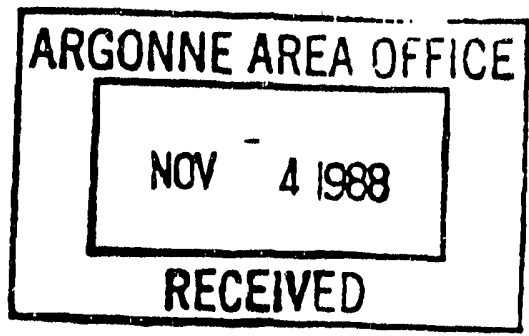


Mr. James E. Evans, P. Z.

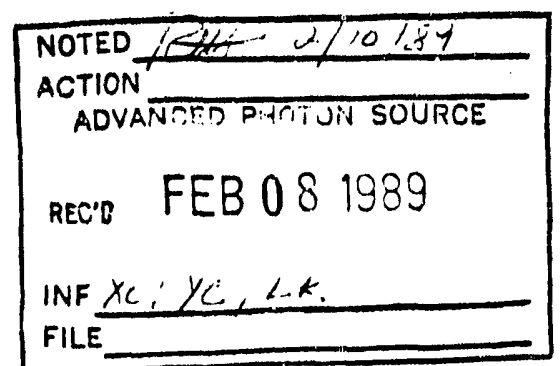

Cinief, Construction-Operations Division

U. S. Army Corps uf Enyigeers

II? S. Jearbora 3 treet

Chicago, IIIInois 50004

Dear ist. Evans:

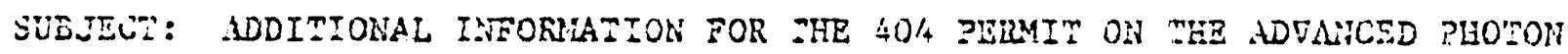
SOIRCE (APS) AI' ARGONNR HATICHAL IABORATOR:

As requested by is. Conztarce Hunt, atzached is the Boncepruai Retiands Hityacion Plan and assoctaced documentation to complete the COE Verlancs perait appication. This perait was jeveloped with consultateon trom a Neclaras scientist (Dr. Courtney lackney, University oi Torth carolina resuge arcacied, and sas discussed ath :9s. Wunt through a conierence caid. The cuncaptual altigaticn plan eepresents the locusent by which boe dnd

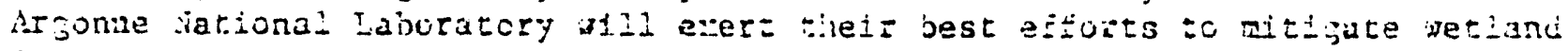

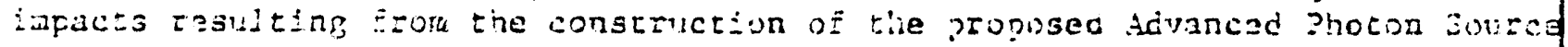
Tacilicy. Detailed angineering spectications for the vetlands created dil be grovidec to the SOE pzior to constuction.

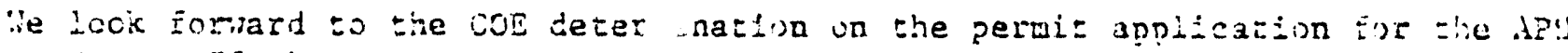
project. If there are any questivas please co not hestiate to call ge ar (311) $372-2432$.

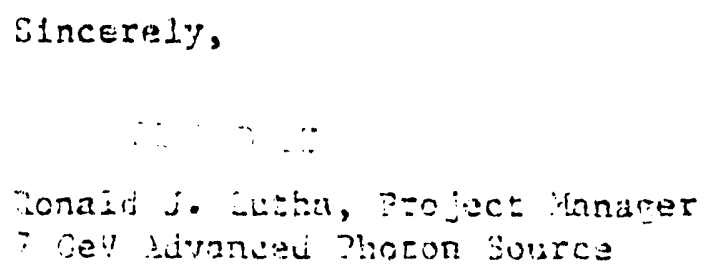

bc w/encl: G. Walach, OCC

$$
\text { B. White, ESHD }
$$

File: $4700 . g 1$ APS

Environmental

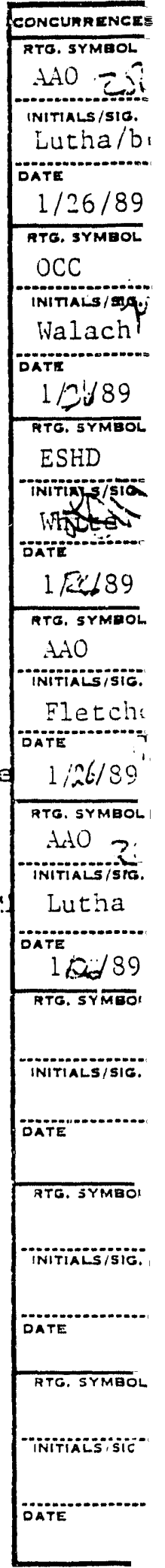


1. Permit Appication Number:

2. Date Permit Application Filed: October 17, 1987

3. Permit Applicant: U.S. Department of Energy

Chicago Operations Office/Argonne Area Office 9800 So. Cass Avenue

Argonne, IL 60439

4. Authorized Agent: Mr. Ronald Lutha, $7 \mathrm{GeV}$ APS Project Manager (312) $972-2432$

5. Project Description: Advanced Photon Source Project

6. Location: Argonne National Laboratory

7. Wetland Mitigation Plan: The conceptual wetland mitigation plan will include the following points --

a. Wetland $C$ ( 1.1 acres) will be avoided during construction of the APS facility (Figure 1). The ecological integrity of wetland $C$ will be maintained by fencing the wetland with about a 30 foot wide buffer and erosion control zone around it. In addition, culverts will be constructed under the road to allow sheet flow to enter or exit the wetland.

b. Wetland areas $A(0.4$ acres $)$ and $B(0.7$ acres $)$ will be destroyed (total of 1.1 acres) during construction of the APS facility. In their place, we plan to construct two wetlands which total 1.8 acres in the general area (about 6 acres) in the southeast corner of the APS site as indicated by the colored region in Figure 1 . These wetlands will be designed to have similar hydrologic and biotic characteristics to those wetlands destroyed.

c. Area E (Figure 1) has wetland characteristics. 01d aerial photographs suggest that this area may have been a wetland prior to construction and subsequent partial filling of the $A^{2} R^{2}$ excavation (Area $D)$. Today tris area shows signs of human disturbance, but 
there may still be some wetland function. To avoid loss of wetland function we nlan to mitigate the entire basin of Area E, 0.7

acres. Loss of this wetland-like area will be mitigated as part of the isolated wetlands already discussed in item $b$ and is included in the 1.8 acre total.

d. One wetland (Figure 2A) will be constructed immediately adjacent to the wooded area in the southeastern part of the APS site. This will provide similar conditions to that present in area $A$ and will provide for the habitat requirements of species which depend on both wetland and forest to complete their life cycle, e.g. tiger salamander. The second wetland (Figure 2B) will be approximately the same size and located farther west in a relatively open area. This will provide similar conditions for development of wet meadow vegetation and habitat.

e. By design, constructed wetlands will not contain standing water at all times during all years, but they will normally contain saturated soils. Such systems can be termed vernal or intermittent ponds. Wetiands to be destroyed have a similar hydrologic regime.

f. Each constructed wetland will have profiles similar to those found in wetlands $A$ and $B$ with the primary goal of creating vegetative zones similar to Figure 2 ( $A$ and $B$ ).

g. We plan to construct wetlands at the beginning of the APS construction during the site preparation phase. Approximately 6 inches of surface soil will be removed from wetlands $A$ and $B$ and graded into each new wetland. Best efforts will be made to avoid soil stockpiling for more than one year. This will provide a viable and natural seed source for most plant species currently present in the wetlands. Plants germinating from the seed bank will be adapted to local conditions and should provide rapid colonization of the constructed wetlands. We al so expect rapid invasion of aquatic insects and amphibians. 
h. Newly created wetlands will have a buffer area of approximately 50 feet from which permanent human structures will be prohibited during and after construction. ATl construction associated with the APS project will use standard methods required by ANL policy that minimize soit erosion and sedimentation in accord with EPA guidelines.

i. Plant species composition will be determined in late spring and summer following construction of the wetlands. Cattails and any other plant species not considered natural or desirable will be removed. Local wetland seed stock and/or native herbaceous species found in other similar wetlands at ANL will be planted if needed to supplement natural recolonization of the constructed wetlands. Woody species such as black willow, silver maple, and rough-leaved dogwood will not be planted until after the second year. All vegetation wi11 be surveyed thereafter through annual summer surveys for a period of 5 years.

j. Detailed engineering specifications for both created wetlands will be provided to the COE prior to construction. Annual reports on vegetation and fauna based on annual surveys will be provided to COE for 5 years after construction of the wetlands.

8. Summary: Two isolated wetiands which equal a total 1.1 acres and a third area (0.7) acres will be destroyed. Two wetlands which will total 1.8 acres will be created very near the original locations in the Des Plaines River Watershed. These will mimic both the physical and biological setting of the destroyed wetlands as closely as possible. A five-year monitoring program will follow their development. 
igure 1. Topographic map of the APS site showing wetland and floodplain areas.

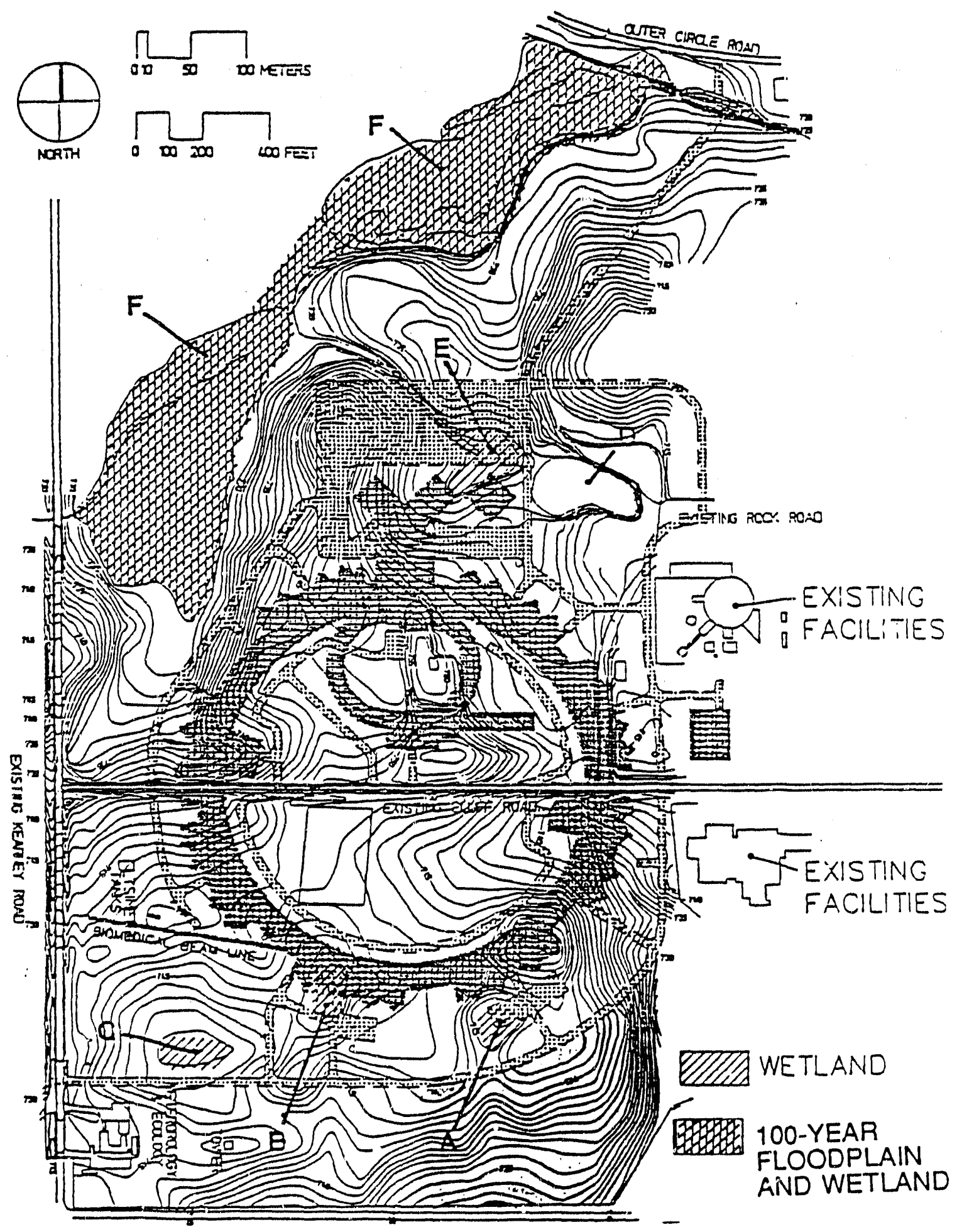

Project Description:

Advanced Pholon

Source Project

- Location: Argonne National

Laborztory. Argunne, lllinois 

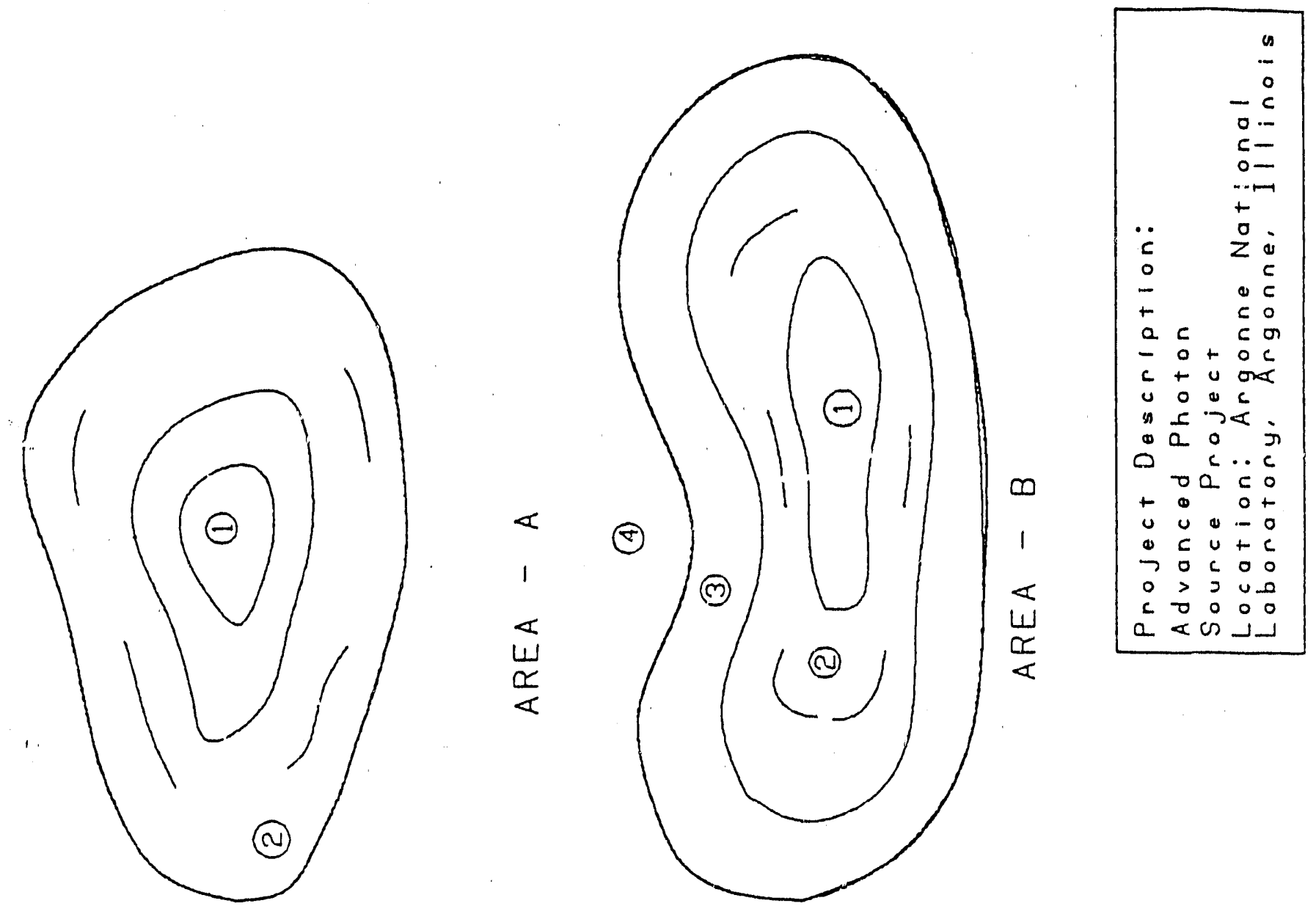

(
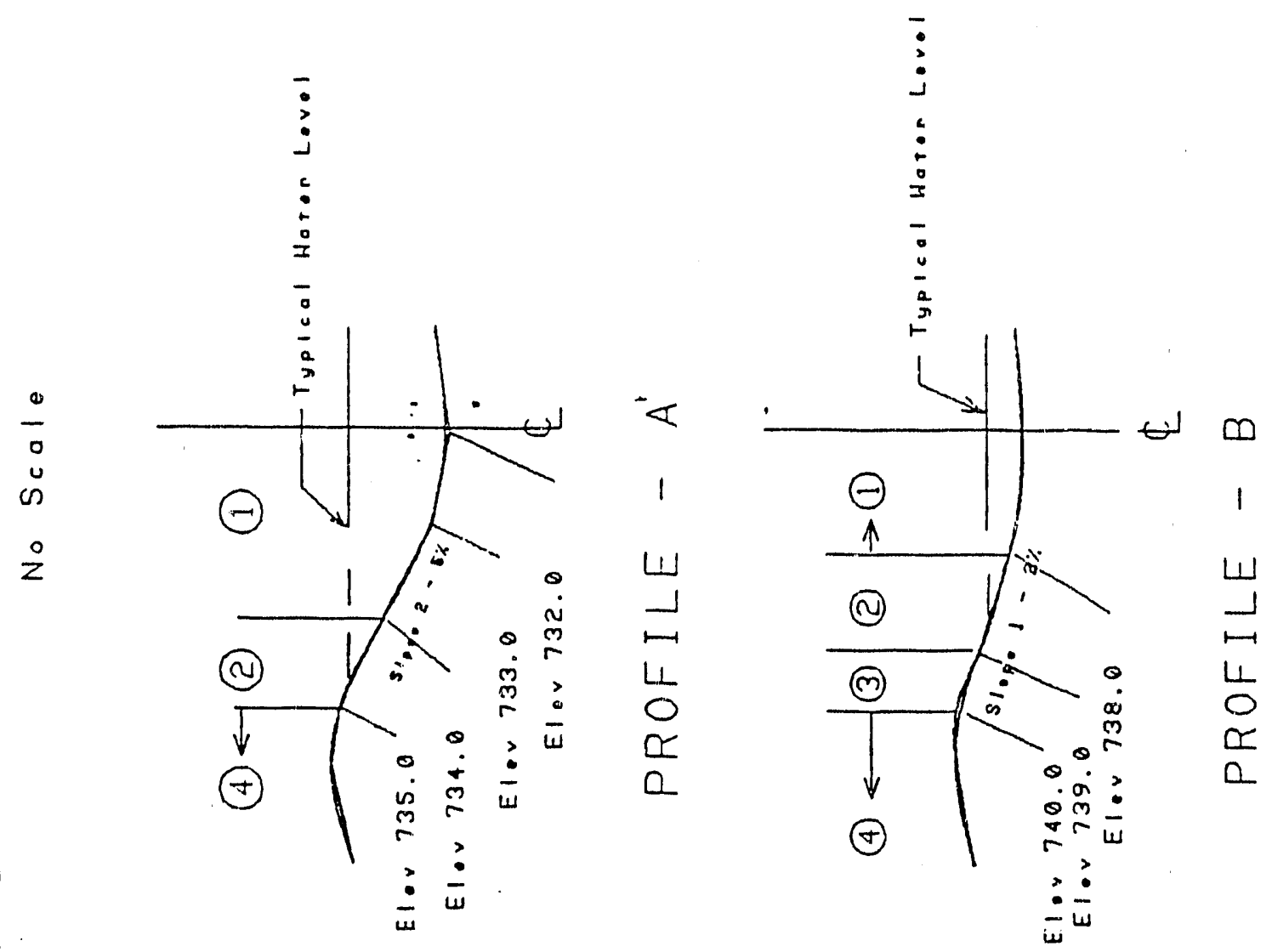

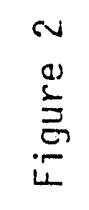




\section{Appendix C}

CORRESPONDENCE REGARDING THREATENED AND ENDANGERED

SPECIES AMONG THE FISH AND WILDLIFE SERVICE,

THE ILLINOIS DEPARTMENT OF CONSERVATION, AND

THE U.S. DEPARTMENT OF ENERGY 


\section{United States Department of the Interior}

FISH AND WILDLIFE SERVICE

ROCK LSLAND FLEL OFFICE (ES)

leso Second Aveaue, Second Floor

Rack lstend, Illinois 61201 in aeply aren ro:

COM : $\quad 309 / 793-5800$

ETS : $\quad 386-5800$

February 9, 1988

Mr. A.L. Taboas

Area Manager

Department of Energy

9800 South Cass Avenue

Argonne, Illinois 60439

Dear Mr. Taboas:

This responds to your letter dated November 20, 1987 requesting iuformal consultation pursuant to the Endangered species Act of 1.973 for a planned $7 \mathrm{GeV}$ Advanced Photon Source Facility at the Argonne National Laboratory. In addition you requested

consultation pursuant to the Fish and Wildife Coordination Act because of potential modification of wetland habitat on the project site.

On February 2, 1988, Gerald Bade of my staff met with Ron Lutha (DOE) and others from Argonne and toured the site. The wetlands in question consisted of palustrine forested and/or emergent types with some value to wildlife such as waterfowl, deer, amphibians, herons and other species. Although the wetlands are rather small in size, we feel any losses should be mitigated.

Mitjgation of environmental impacts generally follows a sequential consideration of avoidance, mininization and compensation of lost values. It is apparent that the placement and design of the facility has already resulted in avoidance and ininimization of impacts as much as is practicable. The remaining undvoidable impacts can then be compensated by either creating new wetland habitat or cuhancing existing low value habitat to laise its value.

Scveral possibilities were discussed for compensation which included 1 l extending the beaver pond northeast of the project site to replace the lost wetland acreage; 2) replacing the beaver dam with a permanent water control structure to insure its future cxistcnce; 3) creating or enhancing additional habitat in an area lical Argonne Park on the cast that could be donated to the DuPage county Forest Preserve District; 4) create or enhance habitat on innds belonging to tho Forest Rresorvo District; 5! 
establish fond plots on unused lands that would be of benefit to wildlife such as deer, pheasant, waterfowl and others. These are merely suggestions and we will be happy to review any proposals your staff develops.

With regard to endangered species, the only Federally listed species in the area is the Indiana bat. We have seen an unconfirmed report of this species being captured in the Waterfall Glen Forest Preserve south of the project. While Indiana bats have been known to forage over upland forests, our main concern is with alteration of nursery habitat. This species generally roosts and rears its young under the loose bark of dead or dying trees that are greater than 16 inches in diameter. Generally, we have found this to occur along the corridor of small streams with a well developed riparian forest on both sides and an overhanging canopy. Since your project does not involve alteration of any such streams, we have determined that it will not effect the Indiana bat. This precludes the need for further action on this project as required under section 7 of the Endangered Species Act of 1973, as amended. Should this project be modified or new information indicate endangered species may be affected, consultation should be initiated.

If you have any questions, please contact Gerry Bade or myself. This letter provides comment under the authority of and in dccordance with provisions of the Fish and Wildlife coordination Act ( 48 Stat. 401 , as amended; 16 U.S.C. et seq.); the National Environmental Policy Act of 1969, as amended; the Endangered Species ACt of 1973, as amended; and in accordance with the Fish and Wildife Service's Mitigation Policy.

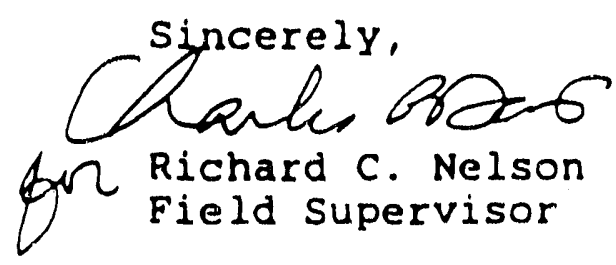

cc. Chicago District IDOC (Schanzlc) 


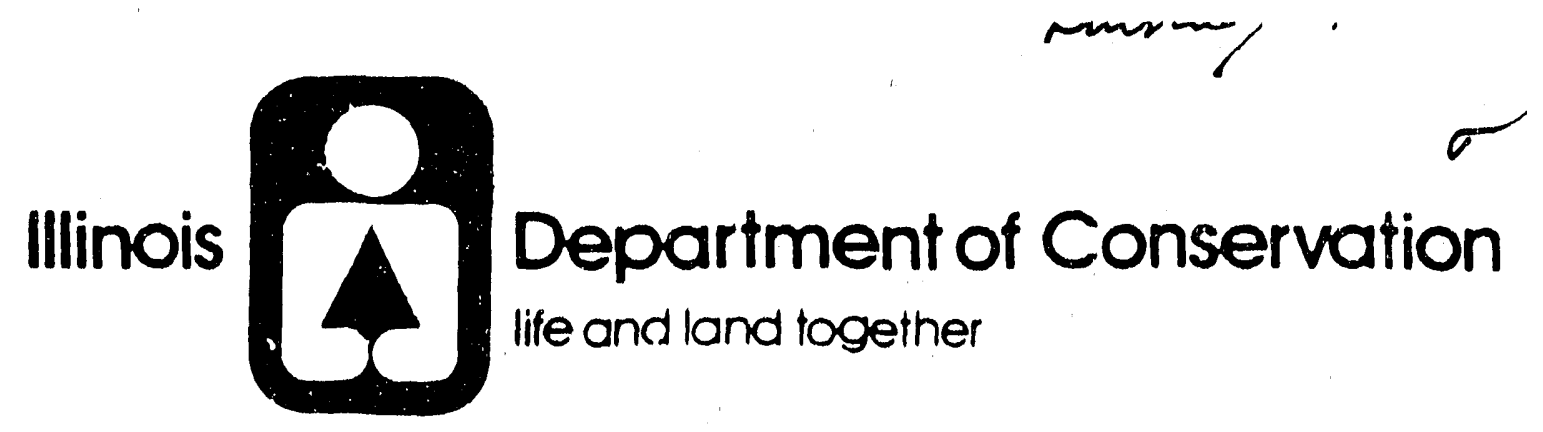

LINICOLN TOWEIT PLIKA - 524 SOUTII SECOND STREET • SPRIPIGFIEI.D 62701.1787 CHICAGO OFFICE • ROOM 1.300 • 100 WEST RANDOLPH 60601 MAFK FIAECH, DIRECTOR

March 7, 1988

Mr. A. L. l'aboas

Department of Energy

Argonne Area office

9800 South Cass Avenue

Argonne, IL 60439

Dear Mr. Taboas:

As per your request, I have checked our database system for occurrences of state listed threatened and endangered species associated with the proposed corstruction site at the Argonne National Laboratory. The search came up with no known threatened or endangered species occurrences. However, since the construction site appears to involve a marsh, a guild of birds associated with marshes should be considered. The guild includes the pied-billed grebe (proposed threatened), yellow-headed blackbird (endangered), common moorhen (threatened), and least bittern (proposed threatened)

Please note that the there is always the potential for additional significant features to occur at a site. This is especially the case with the Illinois Natural Heritage Database, since the database has only been in operation for just over a year and a half.

If I can be of further assistance, please feel free to call me at (217) 785-8774.

Sincerely,

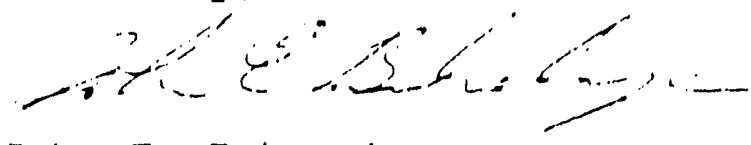

John E. Buhnerkempe

Data Coordinator

Illinois Natural Heritage Database

Division of Natural Heritage

cc: Carl Becker 


\section{Appendix D}

AGENCIES AND PERSONS CONSULTED 


\section{AGENCIES AND PERSONS CONSULTED}

\section{INDIVIDUAL}

James Evans

Constance Hunt

Gerald Bade

Tom Emerson

Paula Cross

Betsy Updike

Tom McCal 7 um

John E. Buhnerkempe

Richard C. Nelson

Courtney Hackney
AGENCY/FIRM

U.S. Department of the Army Chicago District, Corps of Engineers

U.S. Department of Interior Fish and Wildlife Service Rock Is I and Field office

Illinois Historic Preservation Agency

Advisory Council on Historic Preservation

Illinois Department of Conservation

U. S. Department of the Interior

Wetlands Specialist

University of North Carolina 

